\title{
POTENTIAL THERAPEUTIC OPTION USED FOR THE CURE OF COVID-19 USING LOCALLY AVAILABLE INDIGENOUS HERBS (NIGERIA) CONTAINING ANTIOXIDANT, VITAMINS, MINERALS; THUS, THIS WILL HELP TO TACKLE CURRENT STATUS, CHALLENGES AS WELL AS FUTURISTIC PERSPECTIVE GLOBALLY
}

\author{
Silas David Emmanuel1" ${ }^{*}$, I.M. Bugaje², U. Suleman'1, S. M. Mohammmad', B. Aliyu1 \\ ${ }^{1}$ Kaduna Polytechnic Tudun Wada Kaduna State, Nigeria \\ ${ }^{2}$ National Board for Technical Education Kaduna State, Nigeria \\ *Corresponding author: Email: davidsilas 550@g mail.com
}

Cite this article:

Silas D.E., Bugaje I.M. , Suleman U., Mohammmad S.M., Aliyu B. (2021), Potential Therapeutic Option used for the Cure of Covid-19 using Locally Available Indigenous Herbs (Nigeria) Containing Antioxidant, Vitamins, Minerals; thus, this will help to tackle Current Status, Challenges as well as Futuristic Perspective Globally. African Journal of Biology and Medical Research 4(4), 53-117. DOI: 10.52589/AJBMRAFSI6CXU.

\section{Manuscript History \\ Received: 30 Oct 2021 \\ Accepted: 29 Nov 2021 \\ Published: 17 Dec 2021}

Copyright $\odot 2020$ The Author(s). This is an Open Access article distributed under the terms of Creative Commons AttributionNonCommercial-NoDerivatives 4.0 International (CC BY-NC-ND 4.0), which permits anyone to share, use, reproduce and redistribute in any medium, provided the original author and source are credited.
ABSTRACT: Purpose: The unprecedented global pandemic from Covid-19 infection has generated significant chaos to humanity in both health wise and as well as economically. Thus, there have been no specific pharmacological and antiviral therapeutic option to date available for covid-19 management. For these reasons, there have been urgent needs to discover an effective medicine for preventive, and eradication methods due to the hash nature of death toll from this novel corona virus infection. Methods: Repurposing of selection, characterization of bacteria through genomic / traditional, phytochemical and fermentation methods base anti covid-19 drugs discovery. Thus, these approaches and techniques is essential to provides a better lead or otherwise. Results: Taking a bold step of faith to approach the techniques for Covid-19 methods, the results for microbiological screening of bacterial reveals that Bacillus sp (spore former, motile, rod (+) was pin-point to have the highest colony followed by Pseudomonas sp alongside with Klebsiellas $s p($ Capsule formers, motile and rod $(+))$ and the least were found with both shigella sp (none motile, Rod (-ve) and Staphylococcus sp (cocci (+). Phytochemical screening of different plants both in qualitative and quantitative methods using Raphanu satinus, Neem (Azadirachata indica), Bagaruwa (Acacia nilotica), Moringa (Moringa oleifera) etc., respectively contain all the natural antioxidant, bioactive compounds, vitamins as well as an appreciable amount of micronutrient/ macronutrient for combatting covid-19 pandemic. Further investigation through fermentation processes were accentuated with time differences have reveal microbial crude proteins (\%), $\mathrm{pH}$ and dry matter values have significant changes to all the specific species. Thus, there were significant increase in proteins, $\mathrm{pH}$ values decrease as well as dry matter decreases in this order\% Protein $<p H>D M$ respectively. Originality: in view of this current investigation anti covid-19 leads translated 
through microbial screening, phytochemical as well as fermentation processes could overcome the current challenges of covid-19 pandemic therapy. Considering the immense potential of phytochemical, microbiological and fermentation processes, this article summarizes the present status of the research carried out on their anti-covid-19 activities with its limitation and futuristic direction to foster drug discovery.

KEY WORD: Genomic/traditional screening, Phytochemical; Anticovid-19 pandemic; drugs discovery; fermentation

\section{Graphical Abstract}
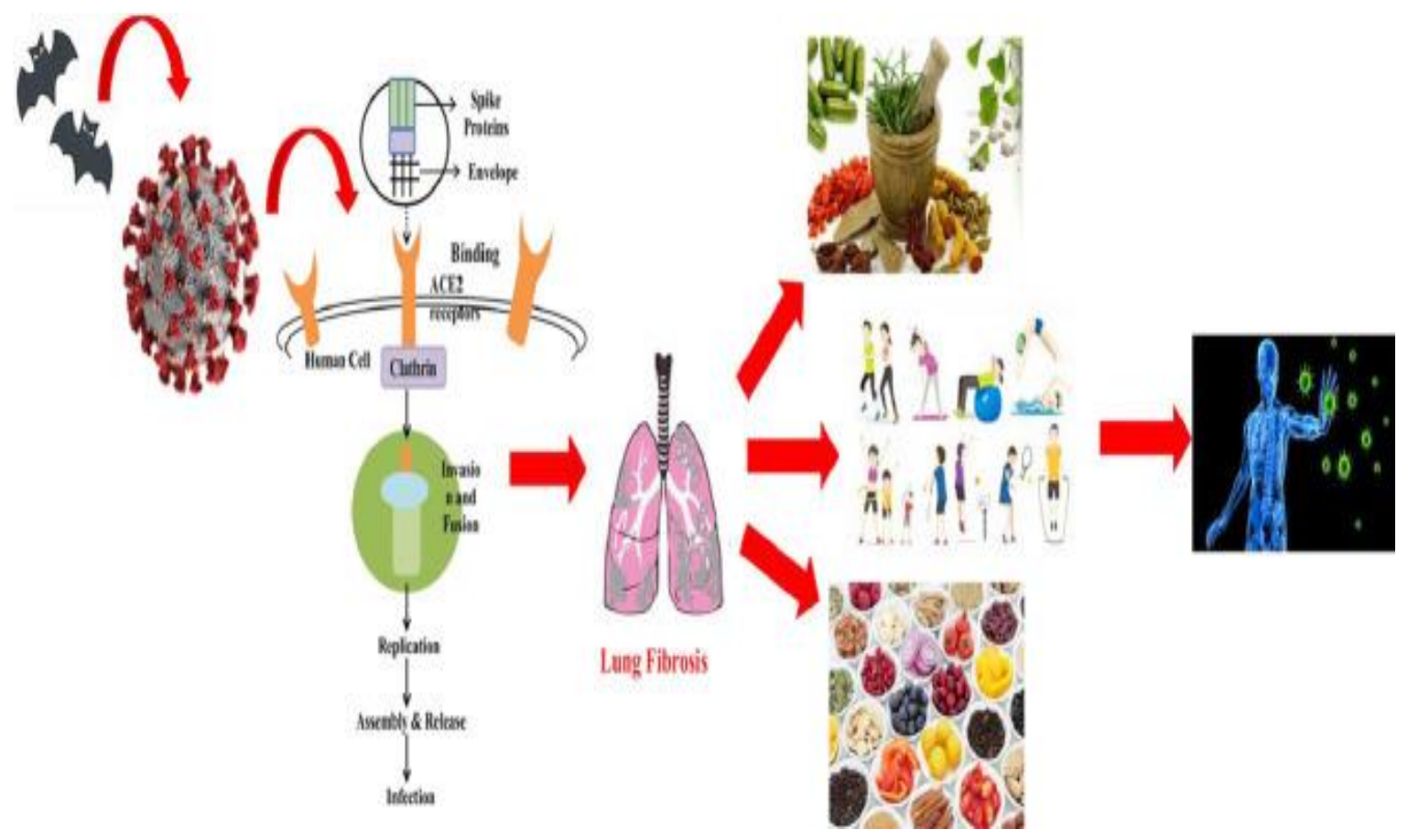


\section{INTRODUCTION}

Pandemic diseases are of global concern in the present era, to cause gigantic morbidity and transience, regardless of, extensive medical facilities. Particularly, anti-viral therapies have been fraught because of surfacing of mutants competent enough to subdue the drugs targeting viral elements [1]. Most importantly, enhanced universal travel and swift urbanization has led to contagious outbreak by rising or re-emergence of viruses, posing a serious menace towards communal health and safety, specifically in such unprecedented times where there are no preventive vaccines available. With the advent of twenty first century, our planet has observed the incidence of catastrophic viral outbreaks namely, SARS-CoV (severe acute respiratory syndrome) and MERS-CoV (Middle East Respiratory Syndrome) within human populace. At present, COVID-19 (Coronavirus) is the third most important disease of animal origin, which is prevailing in almost four corners of the world by getting initiated from a single place. Nearly, 213 countries of all continents have been affected in less than three months by this pernicious virus. After studying its clinical characteristics, experts affirmed that it is quite similar to pneumonia and therefore, named as Novel Coronavirus. However, in the second week of March, 2020, COVID-19 was stated as pandemic by World Health Organization (WHO) [2]. As of August, 24 ${ }^{\text {th }}, 2020$, there have been reported 23,584,259 COVID-19 cases with 812,517 deaths globally as depicted by WHO (WHO, 2020). The causal agent of COVID-19 is SARSCoV-2 (Severe Acute Respiratory Syndrome Coronavirus-2) as per officially named by ICTV (International Committee on Taxonomy of Viruses). After incessant investigations, it has been acquired that SARS-CoV resembles sequence homology with bat coronavirus. Though, its spike glycoproteins have highest affinity for human angiotensin-converting enzyme 2 (ACE2) receptors, that enable them to invade and transmit through human to human. Even though it shares resemblance with SARS-CoV, yet its spreading ability and diagnosis is relatively different. The distinctive feature is most likely the nucleotide pattern of spike proteins along with its receptor binding domains [3]. Moreover, belonging to the category of $\beta$-coronaviruses, a highly prevalent virus family in nature, it has several hosts, natural, intermediate as well as final. Henceforth, it is a colossal issue to prevent and cure the outbreak of this viral infection owing to its greater transmitting and infecting power

\section{PLANT BASED-THERAPEUTIC APPROACHES AGAINST COVID-19}

The traditional medicines have been in general disregarded in the novel research and expansion of contemporary drugs due to the fact that their translational ability is commonly underrated. These medicines are considered vague in the context of their usage in the non-western medical technologies. Wide array of phytochemical components is extracted from a single herb that may function unaided or in amalgamation with other components to yield preferred pharmacological effects. It has been frequently indicated that $70-80 \%$ of the people belonging to the developing countries are directly dependent on the herbal drug for their primary healthcare in comparison to the modern synthetic drugs. Beneficial impact of the medicinal plants lies in their bioactive constituent's specifically secondary metabolites viz. steroids, alkaloids, diterpenes, triterpenes, aliphatic and glycosides etc. [4]. The exploration for innovative phytochemical with antiviral bioactivity has frequently been substandard and inefficient due to adaptive viral resistance accompanied by viral latency and persistent infections in patients with compromised immunity. Most of the antiviral therapeutics' modules are non-specific in their action towards viruses. The progression in development of novel antiviral mediators is the foremost concern of the medical research at present. The antiviral 
bioactivities of plethora of medicinal plants plays a remarkable role in diverse stages of virus growth [5].

\section{MEDICINAL PLANTS WITH ANTIVIRAL PROPERTIES}

Nigerian plants have shown to house a number of novel compounds with antiviral activities. A number of scientific research have elucidated the curative mechanisms by which these plants provide their therapeutic actions while clinical research has presented the ability of some medicinal plants in treating many viral infections and diseases. For instance, Sida cordifolia has been reported to be a natural anti-human immunodeficiency virus (HIV) agent [6]. One of the active compounds isolated from the plant is (10E, 12Z)-9-hydroxyoctadeca-10,12-dienoic acid, a hydroxyl unsaturated fatty acid was found to be an exceptional NES (nuclear export signal) non-antagonistic inhibitor for nuclear export of Rev. Replication of HIV-1 is essentially dependent on the regulatory protein Rev or the Rev protein. Rev protein is involved in the nucleus-cytoplasm export of mRNA, which is very essential for the synthesis of the viral proteins necessary for viral replication. Sida cordifolia has also been proven act as an immune booster serving as immune stimulants to strengthen and harmonize degenerative body systems and assists the immune system in its fight against invading antigens (bacteria and viruses). Another plant with potent antiviral activities is Boerhavia diffusa. Active compound isolated from Boerhaavia diffusa extract is a glycoprotein with a molecular weight between 16,000 and 20,000 . The protein and carbohydrates component of the glycoprotein are about 8 to $13 \%$ and 70-80\% its composition respectively. Other compounds whose biological activity with antiviral properties have been discovered from the plant include: boeravinone, Punarnavine, punarnavoside, hypoxanthine 9-L-arabinofuranoside, liirodendrin and ursolic acid [7]. Recipes from this plant alone or in combination with other medicinal plant shows appreciable antiviral effects against many viruses which cause infections of the respiratory tract, liver and heart diseases. Obviously, there is no uniform principle of action against RNA viruses. Experimental findings on inhibition showed intense and broad antiphytoviral activity which suggested the mode of action of the glycoprotein inhibitor in medicinal plants. This causes a significantly effective antiviral drug candidate to be synthesized in the plant cells, which then offers protection against viral infections [8]. Scientific literatures on Echinacea species have shown its health benefits with special focus often on immunological effects based on in vitro and in vivo studies. Echinacea and its preparations exert immune stimulant activity through three mechanisms: activation of phagocytosis, stimulation of fibroblasts, and the enhancement of respiratory activity that results in augmentation of leukocyte mobility. The production of cytokines (interleukin-1 (IL-1), IL-10) and tumor necrosis factor- $\alpha$ (TNF $\alpha$ ) is stimulated by Echinacea purpurea [9]. Some in vitro studies have proved the antiviral activity of various different preparations of Echinacea. Direct antiviral activity of Echinacea purpurea radix was analyzed by means of a plaque-reduction- assay. The assay showed that the extract caused a $100 \%$ plaque-reduction down to concentrations of $200 \mathrm{ug} / \mathrm{ml}$. The glycoprotein-containing fractions exhibited antiviral activity and decreased plaques numbers by up to $80 \%$. It was concluded that the glycoprotein-containing fractions of Echinacea purpurea root extracts are able to induce the secretion of Il-1, TNF a, and IFN a, j3. Furthermore, they are at least partially responsible for the antiviral activity of Echinacea purpurea radix [10] 


\section{MEDICINAL PLANTS WITH ANTIOXIDANT PROPERTIES}

Medicinal plants with antioxidant properties Numerous plants that grow in Nigeria are wellknown to have countless therapeutic potentials that could be due to their antioxidant properties. Plants are known to be the main source of natural antioxidants in the form of phenolic compounds (phenolic acids, flavonoids and polyphenols). Most of the anti-inflammatory, digestive, neuroprotective, hepatoprotective and nephroprotective drugs derived from natural origin have been reported to have antioxidant/radical scavenging mechanism as part of their activity [11]. The ingestion of natural antioxidants has been associated with the reduced risk of cancer, cardiovascular disease, diabetes and other diseases associated with ageing. Hence, interest has been increased for finding antioxidants of plant source, which are safe and suitable for use in food and/or medicine. In that regard, due to the increasing numbers of diseases ravaging the continent of Africa and of course the World at large there are has been an increase interest in for finding antioxidants from plant source, which are safe and suitable for use in food and/or medicine. For that reason, many indigenous plants were selected for their significant antioxidant activities. The use of artificial and natural food antioxidants regularly in medicine and foods particularly those having fats and oils to shield the food from oxidation. Butylated hydroxytoluene (BHT) and butylated hydroxy anisole (BHA) are some of those artificial natural food antioxidants which have been used expansively in food, cosmetic, and in many healing products industries. Nevertheless, due to the effect of high temperatures which brings instability in them, high volatility, synthetic antioxidant's carcinogenic behavior, users dispositions steered to shift in respect to the producers or manufacturers from man-made to natural antioxidants [12]. Considering the increasing numbers of risk issues of humans to various harmful diseases, this brought about the need for the use of natural constituents present in dietary and medicinal plants as curative and helpful antioxidants. A vast number of indigenous plants in Nigeria have been reported to reveal antioxidant activity, including Allium sativum, Zingiber officinale, Crocus sativus, Dodonaea viscose, Barlerianoctiflora, Anacardium occidentale, Datura fastuosa, Caesalpiniabonducella and many more as in Table 3. Several of these antioxidants from plants has been shown to be an active oxygen scavengers or free radicals, with have no any harmful effect on human body [13]. For detrimental effects of reactive oxygen species to be stopped, plants have shown a powerfully in-built enzymatic and non-enzymatic scavenging capacity. These Enzymes included dehydroascorbate reductase (DHAR), catalase (CAT), glutathione S-transferase (GST), superoxide dismutase (SOD), glutathione peroxidase (GPX), ascorbate peroxidase (APX), glutathione reductase (GR), monodehydroascorbate reductase (MDHAR) and peroxidases (POX) while, non-enzymatic compounds include tocopherols, ascorbate (AsA), glutathione (GSH), and carotenoids. In plants, any form of rise in the levels of antioxidants has been established to exhibit a better resistance to different types of environmental stresses [14]. Consistent eating of dietary foods like fruits and vegetables is well documented to have potentials in the management of various chronic ailments affecting human in Africa. These supplements of antioxidant are directly being obtained from fresh fruits and vegetables, which contain a vast quantity of alkaloids, flavonoids and antioxidant complements which can take part in the defense mechanisms against different cardiovascular ailments including different types of cancers and many health problems. Documented reports have revealed that a diet with rich antioxidants has a great impact on health in many ways such that vast variety of plants and plant parts have been established to contain a large number of antioxidants such as strawberries, Blueberries, grapes, spinach, plums, broccoli flowers, alfalfa sprouts and many more, that have antiviral properties. Citrus fruits like lemons, oranges etc. also contain a high quantity of natural antioxidants, most 
significantly vitamin C. However, there are some new and unique antioxidants like derivatives of flavonoids and p-coumaric acid that have been found in spinach. NAO- a spinach-derived natural antioxidant that contains derivatives of flavonoids and p-coumaric acid plays a significant role in the prevention of prostate cancer as the case may be. Just of recent it has also been established that fruits like araticudomato, pindo palm and jackfruit are good sources of vitamin $\mathrm{C}$, vitamin $\mathrm{A}$ and other phenolic compounds, analysis on these fruits is being carried out to create the genetic, chemical or biological variations so as to enhance the antioxidant potential of the same [15]. Neem (Azadirachta indica) as it is fondly called is a tree inside the family of Meliaceae. Neem is also known as 'Dongoyaro in Yoruba, Atuyabasi/ogwuakom in Igbo and Maina in Hausa word. Seeds, oil, roots, roots, bark, leaves and seeds as part of the tree is somehow bitter and contain compounds with a proven potential as an anti-inflammatory, anti-ulcer and antifungal, antiviral, anti plasmiodal, cytotoxic, antipyretic anti-microbial and antiseptic in nature. The incorporated chemical constituents with many biologically energetic compounds that can be extracted from neem which include flavonoids, alkaloids, carotenoids, triterpenoids, phenolic compounds, steroids and ketones. Azadirachtin is validly an incorporation of seven isomeric J.O. Oladele et al. Heliyon 6 (2020) e04897 9 compounds which was labelled as azadirachtin A-G and azadirachtin $E$ is more efficient [16]. Ginger (Zingiber officinale Roscoe) is an important tropical valued medicinal herb that is found globally as a spice and used for healing and therapeutic proposes. Ginger belongs to the Zingiberaceae family which has been reported to contain over 1250 species in fifty genera, together with 4 other families which is positioned in the order Zingiberales and class Monocotyledones. They have been reported to have many vital pharmacological actions to treat various types of diseases by the actions of antiemetic, antioxidant, anti-cancer, anticoagulant property, anti-inflammatory, and soon. clinical studies have documented its efficacy in treatment of post-operative vomiting and vomiting of pregnancy. The pungency characteristics of the ginger is said to be due to gingerols and shogaols found in them. it has been established that the main components of ginger are the aromatic essential oils, the antioxidants and the pungent oleo-resin also. Pungent compound has been identified as the phenylalkylketones, known as gingerols, shogaols, and zingerone. All main active constituents of Zingiber officinale Roscoe, such as zingerone, gingerdiol, zingibrene, gingerols and shogaols, has been proven to have anti-oxidant activities [17] and this antioxidant activity in ginger is due to the existence of polyphenol compounds like (6-gingerol and its derivatives. The main active constituents of ginger are volatile oil (zingiberene, curcumene, farnesene, zingiberol, D-camphor), Shogaols, Diarylheptanoids, Gingerols, Paradol, Zerumbone, 1Dehydro-(10) gingerdione, Terpenoids and Ginger flavonoids. These compounds give ginger its characteristic hot sensation. Ageratum conyzoides Linn commonly known as Billy goat weeds, belongs to Asteraceae family, an annual herb with a broad history of traditional medicinal use in the tropical and sub-tropical region of the world. Ageratum is derived from the Greek words 'ageras' meaning nonaging which refers to long life-time of plant and the species epithet 'konyz' is the Greek name of Inula helenium which resembles the plant. The stems and leaves of the plant are fully covered with fine white hairs [18]. The analysis of the Ageratum oil sample from Nigeria revealed about 51 constituents which makes it the highest including 20 monoterpenes $(6.6 \%)$ of which $0.5 \%$ contains $\alpha$-terpineol, $1 \%$ of it contains sabinene, $1.6 \%$ contains $\beta$-phellandrene and $\beta$-pinene, $0.6 \%$ contains terpenen- 4 -ol, and $2.9 \%$ contains 1.8-cineole and limonene, and further found 20 sesquiterpenes (5.1\%). Indian Ageratum oil from goat weed is found to contain 5.3\% ocimene which was found in traces from Nigerian plant, $4.4 \%$ eugenol, $6.6 \% \alpha$-pinene, and $1.8 \%$ methyl eugenol [19]. The major sesquiterpenes are beta-caryophyllene, $\delta$ - cadinene, Sesquiphellandrene and 
caryophylleneepoxide. The plant has been examined on the basis of the scientific in vitro, in vivo or clinical evaluations to have possessed the major pharmacological activities that includes analgesic activity, antimicrobial activity, anti-inflammatory activity, spasmolytic effects, gamma radiation effects, anti-cancer and radical scavenging activity, antimalarial activity and others activities based on the listed bioactive earlier discussed [19]. Guava has been reported to have high number of antioxidants and anti-providing nutrients which are very important both for proper functioning of life and help to mitigate free radicals' activities. Guava contained different kinds of phytochemicals which are useful for human health like high blood pressure, obesity and diabetes. Extracts of guava in aqueous and organic solvents have a large quantity of antioxidants which can stop oxidation reactions. Pink guava also has a high antioxidant activity. In fruits, the most abundant oxidants are ascorbic acid and polyphenols. The polyphenols are major flavonoids which are mainly present in glycoside and ester forms. The free ellagic acid and glycosides of quercetin-3-O-glucopyranoside, apigenin, quercetin, myricetin, and morin are found to be present in guava and the presence of all these bioactive make it a potent antioxidant [20]

\section{MEDICINAL PLANTS WITH IMMUNE-BOOSTING PROPERTIES.}

Properties Survival of homo sapiens against traumas from foreign pathogenic microorganisms depend on the status of their immune defense mechanisms. It is well established that the immune system safeguards the host against attacks from infective microorganism such as virus, allergic or toxic molecules [21]. Once a defect occurs within the immune system, it results in response impairment against infectious agents. The cause of impairment (immunosuppression) can be either intrinsic (inherited) or extrinsic and referred to as primary or secondary immunodeficiency respectively. Immunomodulatory agents are non-specific compounds that work without antigenic specificity similar to the adjuvants that are associated with some vaccines [22]. Medicinal plants and natural products with immunomodulatory activities have been employed in traditional medicine and phytomedicine. They improve the humoral and cellmediated immunity and mediate the initiation of "non-specific" immune responses which include the induction of macrophages, natural killer cells, granulocytes, and the complement system. These processes trigger the synthesize and release of diverse molecules such as cytokines which participate in the improvement and modulation of the immune responses [23]. Put together, the entire series of reactions serves as substitutes for the present chemotherapy for immunodeficiency offering protection against infections caused by various pathogenic agents. Plants that are copious carotenoids, vitamin $\mathrm{C}$ or flavonoids can act as an immunestimulant. Medicinal plants that are rich in flavonoids may also possess anti-inflammatory action. They induce interferon production, enhance the activity of lymphocytes and increase phagocytosis. Examples of these immunomodulatory plants include garlic which remarkably enhance immune system activities. Garlic as an immune system booster has been found to exert an immune-potentiating effect by stimulating natural killer cell activity. Some studies strongly present garlic as a promising candidate as an immune modifier, which preserves the homeostasis of immune functions [24] because it has a higher concentration of sulfur combinations which are responsible for its therapeutic effects. Other medicinal plants used by traditional healers as immune boosters are garlic (Allium sativum), guava leave (Psidium guajava), lemongrass (Cymbopogon citratus), cinnamon (Cinnamomum zeylanicum). 


\section{STATEMENT OF PROBLEM}

Current scenario depicts that world has been clenched by COVID-19 pandemic. Inevitably, public health and safety measures could be undertaken in order to dwindle the infection threat and mortality. Moreover, to overcome the global menace and drawing out world from moribund stage, there is an exigency for social distancing and quarantines which is invariably a bonding to humanity globally. Since December, 2019, coronavirus, SARS-CoV-2 (COVID19) have come into existence and up till now world is still in the state of shock by the medical doctors and scientist on how to abate the dreaded killer virus disease pandemic At this point of time, COVID-19 has entered perilous phase, creating havoc among individuals like those of fever, cough, fatigue, sputum production, While, symptoms such as shortness of breath, myalgia, sore throat, headache, chills, are common, gastrointestinal symptoms such as vomiting, diarrhea along with anosmia etc., respectively. Thus, these results are consistent with previous studies conducted on severely ill patients which also advocates high mortality rate in elderly people with acute respiratory distress syndrome (ARDS) and comorbidities such as perpetual hypertension, perpetual diabetes, chronic obstructive lung disease, ulcer, pile and coronary heart disease. The clinical attributes also are habituated with RNA analysis of SARSCoV-2 revealed that the viral particles can infect these cells therefore, it is quite predictable that sexual intercourse could be the possible way of contagion. There have been cases when person shows negative results on nasopharyngeal swabs, while, positive on rectal swabs, depicting that sexual transmission might be the possibility [25]. Henceforth, the physicians as well as transpiring doctors in particular recommend a strong message to discourage sexual practices if in any case of COVID-19 infection within affected patient; otherwise, it would have been the cases of HIV/AIDS which have ravaged so many lives to their early grave since 1981 . However, these non-challans or deliberate satanic attitudes by the medical doctors/ scientist in their secretive occults meeting must be stop with immediate alacrity otherwise they would face the wrath of God within their circular family from one generation to another generation.

\section{RATIONAL/ JUSTIFICATION OF THE STUDY}

The rationale of the study was to address the health burden in terms of 12 both medicine and nutrition intervention. This was done stemming from the first principles of use which is indigenous knowledge information. This is why this study was set out to document and validate the herbal and nutritive plants; and their practices in the management of covid-19 - related infections. Efforts geared towards improving the quality of herbal medicines will in turn improve the quality of health, nutritional status and economic empowerment of the people involved in the conservation, collection, preparation and administration of these plant products. Hence the value of this research lies not only in promoting the value of nutria-medicinal plants in the context of covid-19 epidemic, but also in the need for improved primary health care. Further investigation of this current study was also to provide insights regarding the possibilities of the most important natural antimicrobial compounds derived from plant sources containing a wide variety of secondary metabolites, which are useful as alternative strategies to control microbial infections in covid-19 patients. As a result, many herbalists stand to set up more therapy centers sometimes to receive greater numbers from time to time 


\section{SIGNIFICANCE OF THE STUDY}

Documentation of plant species with active compounds against Covid-19 opportunistic infections helps to preserve or keep important indigenous knowledge safe. The key to medicinal plants research revolves around the detection, isolation and characterization of active compounds as therapeutic agents. Scientific validation of herbal medicines provides basic understanding of a plant's efficacy and this may lend further support to the widespread use of TM in health care systems, provided toxicological investigations are carried out. Several herbs have been attributed to improve immune response and could reduce symptoms of Covid-19; however, this needs scientific validation in terms of safety and efficacy. Information on safety and toxic levels of the plants can be a starting point for the formulation of dosage levels of the herbal remedies. Bioactivity analysis may lead to the identification and isolation of novel chemical compounds and may confirm which plants are useful as nutraceutical and pharmaceutical products in the management of covid-19 related infections. With increasing antibiotic resistance, it is important to find effective treatments for microbial infections. However, routine testing for chemical composition, biological activity and toxicity of plant derived natural products are all critical attributes to be considered for a complete understanding of the effect of medicinal plants on human health care.

In view of the current investigation this article is set out to document and validate the herbal and nutritive plants; and their practices in the management of covid-19 related infections. Efforts geared towards improving the quality of herbal medicines will in turn improve the quality of health, nutritional status and economic empowerment of the people involved in the conservation, collection, preparation and administration of these plant products. Hence the value of this research lies not only in promoting the value of nutria-medicinal plants in the context of HIV/AIDS epidemic, but also in the need for improved primary health care.

\section{MAIN OBJECTIVE}

"Potential therapeutic option used for the cure of covid-19 using locally available indigenous herbs (Nigeria) containing antioxidant, vitamins, minerals; thus, this will help to tackle current status, challenges as well as futuristic perspective globally"

\section{The specific objectives of the study were to:}

* To Identify and document plant species with nutritional and medicinal properties.

* To Determine the antioxidant and antimicrobial properties of the selected plant species.

To Identify the bioactive molecules in the most active plant extracts.

To Determine the toxic levels of the most active plant extracts using animal models. 


\section{RESEARCH QUESTIONS}

- What medicinal plants are used to treat/manage covid-19 immune compromised ailments?

- What are the nutritive and medicinal values of the used plants?

- What are the active chemical compounds responsible for bioactivity in the screened plant extracts?

- Are the plants raw materials safe for use as functional foods and pharmaceuticals?

\section{LITERATURE REVIEW}

\section{ORIGINE AND TRANSMMISION OF CORONA VIRUS}

The natural reservoir for both the SARS-CoV and MERS-CoV were bats; however, these viruses infect humans through an intermediate host. Palm civets are supposed to be the intermediate host of SARS-CoV while dromedary camels are of MERS-CoV [26]. Unfortunately, the exact zoonotic origin of SARS-CoV-2 is still elusive. Since SARS-CoV-2 shares $88 \%$ nucleotide homology with two SARS-like CoV found in bats (bat-SL-CoVZC45 and bat-SL-CoVZXC21) and 96\% with RaTG13 virus found in horseshoe bat (Rhinolophus affinis), bats are considered to be its natural host. Despite the $96 \%$ nucleotide similarity, the RBD of both the viruses varies significantly. However, due to the ecological separation of the bats from the humans and the requirement of some necessary mutations in the virus genome to cross the species barrier, SARS-CoV-2 likely has one or more mammalian intermediate hosts for efficient animal-to-human transmission. Analyses of interactions between RBD in SARSCoV-2 and ACE2 receptors in different hosts indicate that pangolins, snakes, and turtles may be the immediate host of SARS-CoV-2 [27] fig1. Recent phylogenetic studies on the genome of Pangolin-CoV found from dead Malayan pangolins, which are illegally imported in China revealed that its genome is about $91 \%$ identical to SARS-CoV-2 and around $90 \%$ to RaTG13 (Bat-CoV). Besides, five of the six amino acids (contact residues) on RBD, vital for binding to ACE2 receptors on hosts are consistent between SARS-CoV-2 and Pangolin-CoV, but only four between Pangolin-CoV and RaTG13 and only one out of six between SARS-CoV and SARS- CoV-2. These findings suggest the probability of pangolins as natural reservoirs of SARS-CoV-2. More and more studies with a wider sampling of mammals from China's wildlife markets or that are in close contact with humans like these are needed to resolve intermediate hosts of SARS- CoV-2 [28]. 


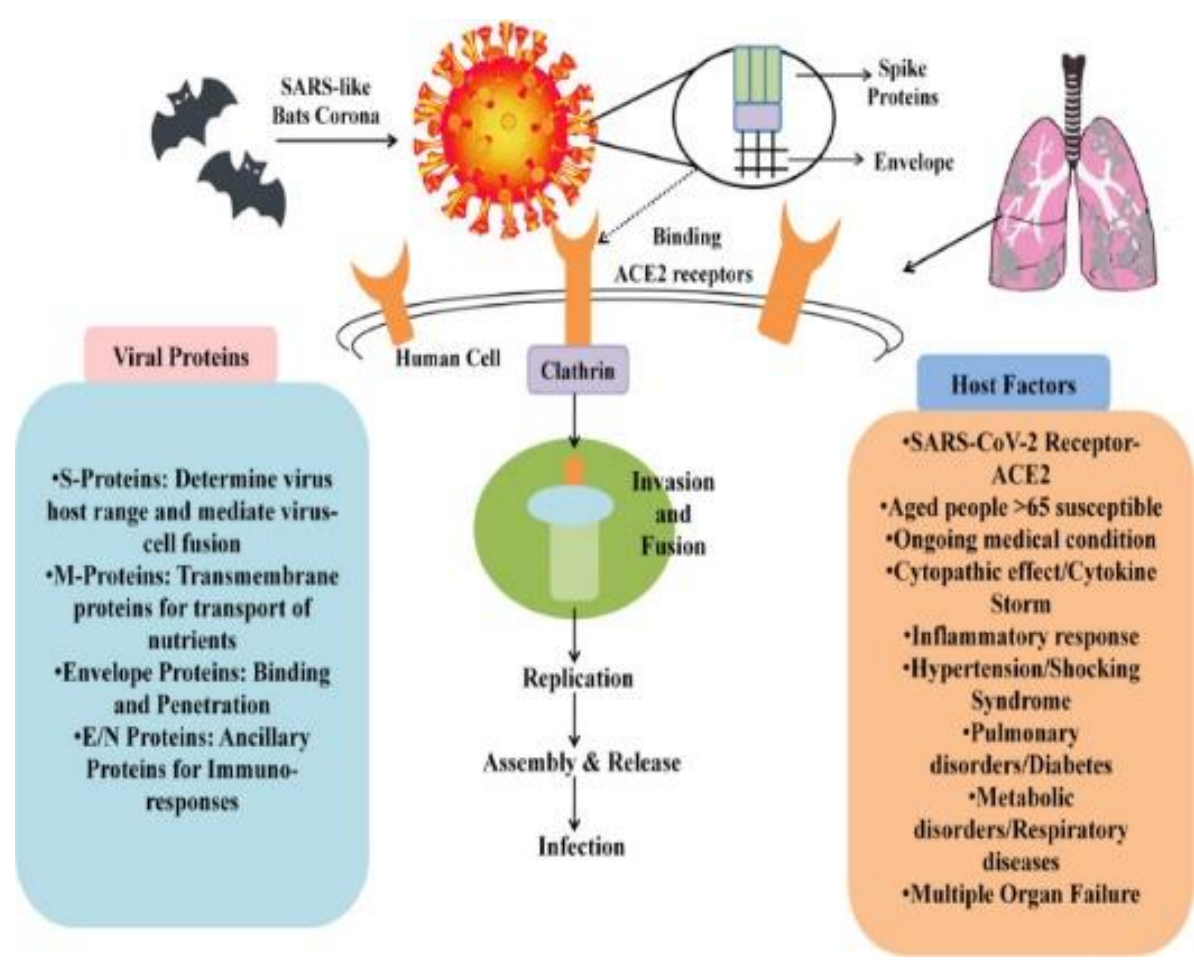

Fig. 1 Schematic Presentation of COVID-19 Binding to Host Cells, Invasion, Replication, Assemblage, Release and Infection Along with the Associated Host and Viral Factors. Fig. illustrates the origin of coronavirus from bats; the viral structure comprises of spike proteins that enable attachment and virus is enveloped in nature for protection as well as facilitation of viral entry; the viral particles bind onto ACE2 receptors of host cells; clathrin is associated with coating membranes for endocytosis from the plasma membrane; viral particles are invaded and fused followed by replication; assembly and release of viral particles occurs to initiate the

\section{HUMAN-TO-HUMAN TRANSMISSION ROUTES}

Person-to-person transmission is primarily reported in families, communities, and hospitals droplet transmission is considered as the main route of person-to-person transmission. The infection also spreads through direct contact and via fomite exposure i.e., direct contact to eyes, nose, and mouth after touching surfaces and objects contaminated by an infected individual. In general, human-CoVs can remain infectious on some material surfaces for even 9 days. Besides, SARS-CoV-2 also spreads through contact with asymptomatic carriers [29]. Since SARS-CoV-2 infection is spreading at an unprecedented pace, airborne transmission too warrants meticulous determination. In addition, SARS-CoV-2 was found in a stool sample, gastrointestinal tissue even urine and saliva of an infected person, suggests the possibility of intestinal and fecal-oral transmission. Although no case of mother to child transmission has been reported yet, infection in two newborns of Wuhan, China raises the question for vertical transmission. Apart from this, there are recent studies that reveal that there is a possibility of 
sexual transmission of COVID-19 infection. There is an array of evidences for this transmission such as through faecal-oral route via gastrointestinal infection. This is most probably due to ACE2 that enable virus entry and ACE2 mRNA is overexpressed in gastrointestinal system as revealed through immunofluorescent analysis of rectal epithelial cells [30]. Moreover, RNA analysis of SARS-CoV-2 also revealed that the viral particles can infect these cells therefore, it is quite predictable that sexual intercourse could be the possible way of contagion. There have been cases when person shows negative results on nasopharyngeal swabs, while, positive on rectal swabs, depicting that sexual transmission might be the possibility [31]. Henceforth, the physicians as well as doctors in particular recommend a strong message to discourage sexual practices if in any case of COVID-19 infection. Hence, comprehensive possible means of SARS-CoV-2 transmission warrants further study

\section{SECONDARY PLANT METABOLITES AGAINST COVID-19 VIRUS}

\section{Terpenoids}

The triterpenes are composed of 6 isoprene units and with squalene as a prototype and are diversely occurrence in plant species. They play a vital role in modulation of cellular metabolism, specifically the biosynthesis of sterols and have a significant level of antiviral activity. Various triterpenes have been reported to have effect against HSV1 and HSV2 these include dammaradienol, dammarenediol-II, dammarenolic acid, hydroxyhopanone, hydroxydammarenone-I, shoreic acid, ursonic acid, hydroxyoleanonic lactone and eichlerianic acid [32]. Structurally coronavirus is composed of single stranded RNA, reported to be one of the longest RNA virus. This RNA strand acts as an RNA messenger, when it transmits into a cell it stimulates the synthesis of two polyproteins which are further composed of a novel replication and transmission complexes that regulate the synthesis of RNA, structural proteins and enhance the activity of protease enzyme. Here protease enzyme has a significant participation in fragmentation of the polyprotein. Apart from designing and chemical synthesizing of protease inhibitor, one of the most recent therapeutic strategies to cure viral infection is to identify the inhibitors of these enzymes in natural products and compounds. Amongst these, terpenoids have a specific significance due to fact of diverse availability in plants and microorganism and low inhibitory concentration i.e., IC50. The terpenoids are the chief secondary metabolites present in more than 36,000 species accounted so far. These secondary metabolites have multifaceted therapeutic application viz. anti-cancerous, antiinflammatory and antiviral (, antioxidant [33] and antibacterial.

In a recent report by the structure of terpenoid constituents and COVID-19 protease was elucidated from the different databases such as PubChem and Protein Data Bank (PDB). Followed by this, the sophisticated technique of molecular docking was utilized by employing MVD (molegro virtual docker) software. 9 and different terpenes were analyzed for their inhibitory effects. These included thymoquinone extracted from Nigella sativa. Molecular dynamic simulations have also shown that thymoquinone can interact with the attachment of SARS-CoV-2 to the HSPA5 substrate-binding domain b (SBDb) to stress cells and thus reduce the possibility of infection [34]. Nevertheless, it is potentially time to switch thymoquinone from experiments on the bench to clinical trials for the Covid-19 pandemic. Salvinorin A derived from Salvia divinorum, Bilobalide and Ginkgolide A extracted from Gingko biloba, citral from Backhousia citriodora, menthol from Mentha, Noscapine extracted from Papaveraceae family, Forscolin from Plectranthus barbatus and Beta Selinene from Apium graveolens. The fallout of this experiment illustrated the strapping interactions of terpenoids in 
the two enzymatically secluded regions. The fastening of varied amino acids as they were present in the secluded regions of the active site in all the 9 compounds was observed and plays a significant function in enzymatic catalysis. It was further revealed in the study that terpenoids were able to successfully suppress the virus protease enzyme activity. Another report by Chowdhary et al. (2003), suggested antiretroviral and anticancer activities of Betulinic acid a pentacyclic triterpenoid which was extracted from the bark of white Betula alba var. pubescens tree. The betulinic acid was observed to cause apoptosis by modulation of mitogen activated protein kinases (MAPK) cascade and subsequently resulted in activation of caspase enzyme, changes in mitochondrial membrane and DNA fragmentation [35].

\section{Polyphenols/flavonoids}

Amongst many groups of substances polyphenols display a wide range of biological activities. Polyphenols are known to increase the immune to cells to foreign infestations and in response permits cellular accumulation of different types of polyphenols through varied receptors. This subsequently triggers signaling pathways and initiate immune responses [36]. The natural polyphenols were identified as potent COVID-19 protease $\left(\mathrm{M}^{\mathrm{pro}}\right)$ inhibitors in an in-silico study conducted by [37]. In this study, efficiency of medicinal plants based on bioactive constituent's viz. flavonoids were analyzed against COVID-19 Mpro and was carried by using molecular docking technique. The COVID-19 virus was docked with 80 different flavonoids and the results indicated that compound such as rutin, apiin, hesperidin, diosmin and diacetylcurcumin etc. had an effective inhibitory effect on protease enzyme and they might have a role in lowering the symptoms of COVID-19 infection.

An imperative class of plant secondary metabolites is flavonoids with antiviral therapeutic potential with more than 5000 different compounds identified and described [38]. These secondary metabolites are considered one of the most profusely present polyphenols in the human diet and are generally found as glycosides and acyl glycosides in vegetables and fruits. There are wide array of flavonoids present naturally in plants including quercetin, naringin, hesperidin and catechin and they have been analyzed for their activity against plethora of animal viruses such as HSV-1, respiratory syncytial virus, parainfluenza virus type 3 and poliovirus type 1 . The anti-viral activity of flavonoids was reported earlier, against Rou's sarcoma, pseudorabies, adenoviruses, Sindbis and also against severe acute respiratory syndrome coronavirus (SARS-CoV) [39]. The main mechanism by which they suppress the viral infection is by inhibition of cellular receptor kinases including MAPKs, the serine/threonine-specific protein kinase (Akt) and the phosphatidylinositol-4,5-bisphosphate 3-kinase (PI3-K) and as consequence interferes with the cellular signal transduction cascades.

Glycyrrhizin is the chief constituent of Glycyrrhiza glabra root and are rich in flavonoids, $\beta$ sitosterol, hydroxyl coumarins and glycyrrhetinic acid. Glycyrrhizin, since the ancient times have been employed in treatment of various ailments including bronchitis, gastritis and jaundice. Furthermore, they have been affirmed to have anti-inflammatory and antioxidant potential that induce the formation of interferons in human body. It was observed by [40] that Glycyrrhizin lowers the ability of SARS-Cov agents to attach to the cell particularly in the early stages of viral infestation. Similar, observation of imperative anti-SARS-CoV activity as shown by Glycyrrhizin was made by [41]. More recently, the in-silico experimentation revealed that Glycyrrhizin has similar behavior against COVID-19 disease and acts as a potential inhibitor. 
Baicalin, another significant flavone glucuronide extracted from Scutellaria genus has been reported to have antioxidative and anti-apoptotic activity and it has been employed in treatment of diseases like pulmonary atrial hypertension. The anti-SARS-CoV potential of baicalin was initially observed by,[42] who suggested strong inhibitory effect and considerably lower toxic implications on the plant cell lines in-vitro. The in-silico experimentation with baicalin resulted in stimulation of certain compounds that suppressed the COVID-19 infection as a consequence of ACE2 enzyme activation. A flavanone glycoside isolated from citrus fruits is Hesperidin, which has been reported to work against COVID-19. Hesperidin rich citrus peel from the waste were used in the study which underwent hydrodynamic cavitation-based speedy expansion and act as antiviral agent against COVID-19. Fig. 2 elucidates prospects of augmentation in immuno-modulatory responses against COVID-19 by polyphenols/flavonoids and terpenoids.

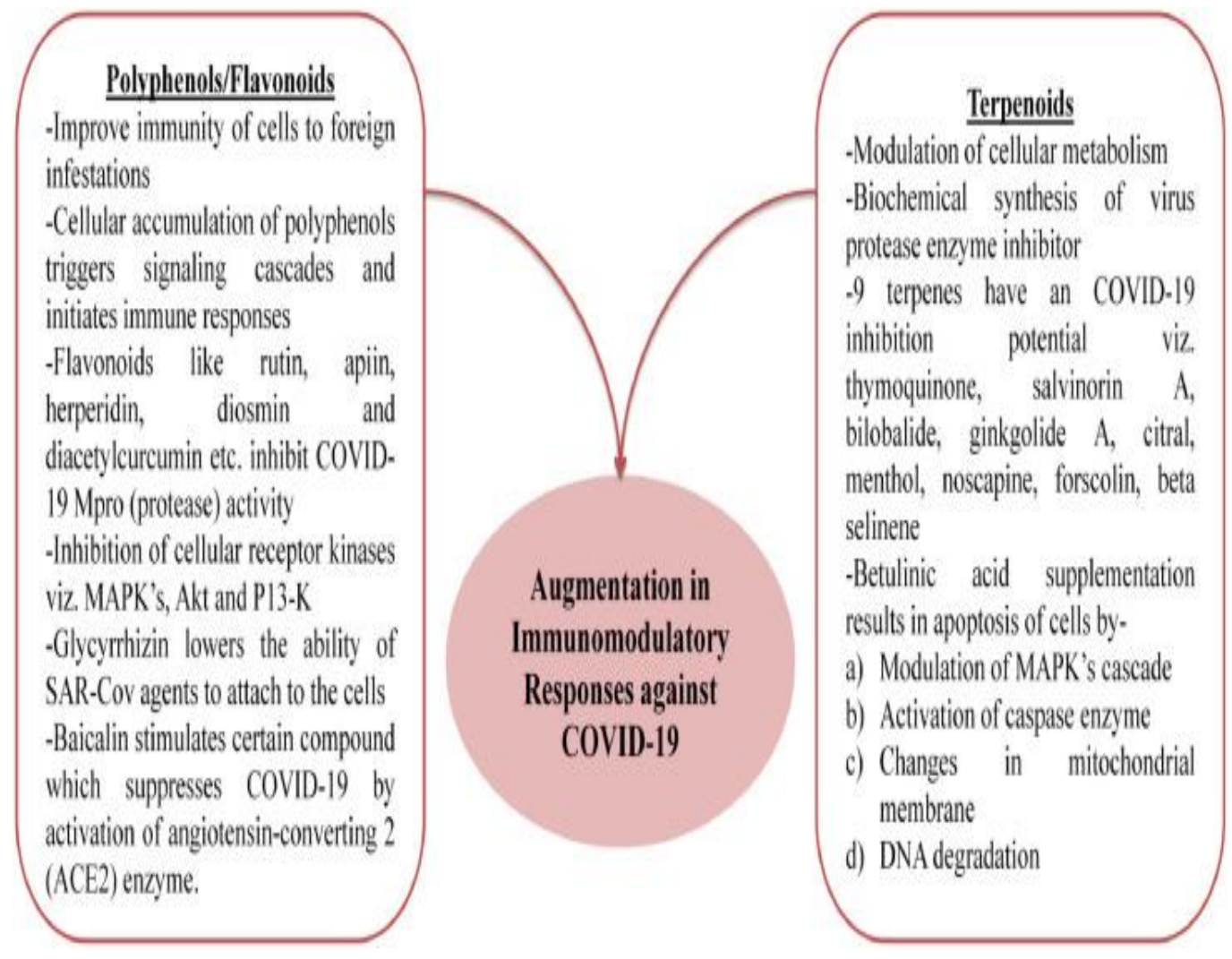

Fig. 2 Prospects of Augmentation in Immuno-Modulatory Responses against COVID-19 by Polyphenols/Flavonoids and Terpenoids.

\section{GROWTH PHASES AND SECONDARY METABOLITES}

The growth of microorganisms is a highly complex and coordinated process, ultimately expressed by increase in cell number or cell mass. The process of growth depends on the availability of requisite nutrients and their transport into the cells, and the environmental factors such as aeration, $\mathrm{O}_{2}$ supply, temperature and $\mathrm{pH}$. 
Doubling time refers to the time period required for doubling the weight of the biomass while generation time represents the period for doubling the cell numbers. Doubling times normally increase with increasing cell size and complicity as given below. In general, when all other conditions are kept ideal, growth of the microorganisms is dependent on the substrate (nutrient) supply. The microorganisms can be grown in batch, fed-batch, semi-continuous or continuous culture systems in a bioreactor [43].

The growth of bacterial culture can be represented by a curve that consist of four stages or phases

- Lag phase - growth and reproduction are just beginning

- Log phase- reproduction is occurring at an exponential rate

- Stationary phase- environmental surroundings and food supply cannot any more exponential growth, therefore growth slows down.

- Death phase- when all of the nutrients have been exhausted, the population die off

The production of secondary metabolites (such as antibiotics) often occurs during the stationary growth phase (or idiophase) of bacterial culture. Secondary metabolites are non - growthgrowth related and seem to play no obvious role in the cell maintenance. The production of secondary metabolites largely concerns the first growth phases of a bacterial culture. This production is considered a two-stage process, with a trophophase (growth phase)- and an idiophase (production phase), which usually occurs when culture growth has slowed or ceased. The major aim for mass production of secondary metabolite is to maximize the biomass in a short trophophase, while optimizing the condition for high, sustained production

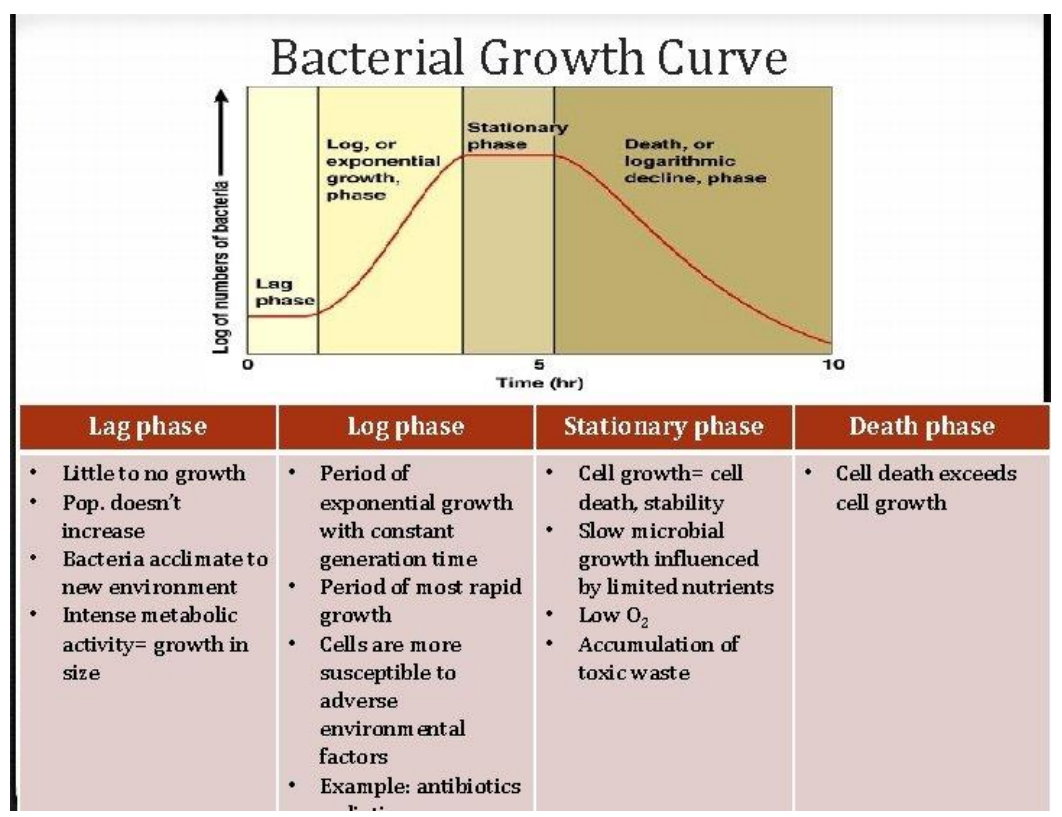

Fig 3 Posts growth phases in bacterial culture growth

\subsection{CULTURE CONDITIONS}


A variety of parameters are important to influence the production of desire secondary metabolites in bio reactor cultures. These includes:

- Substrate

- Slow or fast utilization

- Nitrogen requirements

- Amino acids supplements

- Temperature

- $\mathrm{pH}$

- Oxygen

- Pressure

\section{TYPES OF BIOREACTORS}

Several types of bio reactors enjoy the use in both research and industry. Here are some of the most common

- Stirred Tank- mechanical mixing and air-spared media

- Air lift- uses air sparing to pneumatically mixed the media

- Combinations and variations of stirred tank and airlift reactor

- Membrane- two permeable membranes to deliver nutrients and export waste and products from bacteria in a center tube

Bacteria and plant cultures can be grown in bioreactors using several modes of operation including: batch, semi batch or continuous.[44]

\section{THE ACHIEVEMENT AND MAINTANANCE OF ASEPTIC CONDITION}

It is necessary to be able to sterilize and keep sterile fermenter and its contents throughout the complete growth. The following operations during fermentation are as follows;

(i) Sterilization of the fermenter (ii) sterilization of the air supply (iii) aeration and agitation (iv) the addition of inoculum, nutrients and other supplements(v) sampling (vi) foam control (vii) monitoring and control of various parameters [45]

\section{ASEPTIC OPERATION AND CONTAINMENT}

Containment involves prevention or escape of viable cells from a fermenter or downstream equipment and is much $\mathrm{m}$ more recent in origin. Containment guideline was issue in 1970s (East et al., 1984). Criteria to assess risk was explained by (Collins, 1992) in the following manner; 

a) The known pathogenicity of microorganism
b) The virulence or level of pathogenicity of the microbe are the disease it causes mild chronic
c) The number of organisms require to initiate an infection
d) The route of infection
e) The known incidence of infection in the community and the existence locally of vectors and potential reserve
f) The amount or volume of organism in the fermentation process
g) The technique or process used
h) Ease of prophylaxis and treatment

\section{CRITERIA USED FOR THE SELECTION OF MICROORGANISMS FOR FERMENTATION}

The selection of microorganisms used in fermentation processes and the methods used for the maintenance of these organisms are among the most important decision that have to be made in designing an industrial fermentation process. the microbes must have the following attributes

i) The strain must be genetically stable

ii) The strain should be readily maintained for reasonably long time

iii) The strain must readily produce many vegetative cells, spore cell capsule cells or other structure $\mathrm{s}$

iv) The strain should grow vigorously and rapidly after inoculation into inoculum vessel in the fermentation unit

v) The strain should be in pure culture, free from other microorganisms including bacteriophages

vi) The strains should be amenable to change by the certain mutagens or a group of mutagenic

vii) The strains should be able to protect themselves from contamination [46]

\section{PRODUCTION OF MICROBIAL PRODUCTS}

Wild strains of microorganisms produce low amount of commercially important products; therefore, investigation needs to be made to increase the productivity of selected organisms. To achieve the increase yield optimization, the culture medium and the growth conditions are the major pre-requisites through which the potential productivity of the microorganisms is control or regulated by the its genome. Thus, the genome must be modified so as to enhance the productivity. The modified microorganisms have different nutritional requirements with different culture condition such as temperature, $\mathrm{pH}$, oxygen requirement etc., respectively. 
These factors provide benefits to the process of strain improvement involving genome modification of the microorganisms followed by reappraisals of its cultural requirements [47].

\section{GENOMIC STRAIN IMPROVEMENT OF MICROORGANISM}

\section{Method of genomic strain improvement}

A mutant requiring Oleic acid for neomycin formation by Streptomyces fradiae showed a decrease in the intracellular level of neomycin precursors in mutant. On the other hand, super sensitivity mutants of $\beta$ - lactam antibiotics are another example. Recent approaches towards strain improvement are given below:

a) Role of Plasmid: Plasmid gene are involved in antibiotic production in Streptomyces sp Although plasmid is involved in genetic characteristics in curing experiments involvement of plasmids in biosynthesis of aureothricin and kasugamycin in Streptomyce kasuaensis was demonstrated more than a decade ago by [48]. The genetic study using Streptomyces venezuela ISP 5230. A chloramphenicol (CM) producer, contain most of the structural gene for the CM biosynthetic steps treated between met and ilu on the chromosome. Thus, the plasmid played role in increasing CM production. A linear plasmid like DNA (pSLA2) of 11.2 x106 Dalton molecular weight from Streptomyces sp produced antibiotics.

b) Protoplast fusion: Protoplast Fusion is one of the useful techniques for obtaining hybrids or recombinants of different microorganisms' strains. Various studies have been carried out by using protoplast fusion in Streptomyces, Saccharomyces and fungi. Protoplast formation in Streptomyces sp was first reported by Okanishi and his team in the year 1966. Furthermore, they have worked on formations stabilization and regeneration of protoplast of Streptomyces grieseus and Sreptomyces venezuela. Fusion of yeast protoplasts have been reported with Sacchromyces cerevisiae, technique for protoplast fusion in Brevibacteria flavum has been use for strain improvement.

c) Mutations: Screening after major subjection of a parent strain to physical or chemical mutagen has been greatly increased the probability of finding improve strain

d) major mutations: it involves the selection of mutants with a pronounced change in a biochemical character of practical interest. Such variants are commonly used in genetic studies and are generally 'low mutants' they are isolated routinely from population surviving after prolonged exposure to a mutagen, for example, selection of nonpigmented Penicillium chrysogenum strains with high penicillium production. The initial strain of Streptomyces grisieus (a streptomycin producing organism) synthesized the small amount of streptomycin but its variant was isolated and produced greater amount of streptomycin. For further improvement, it is also necessary to study the biosynthetic pathways which contribute to the identification of precursors as in case of modified tetracycline synthesized by a mutant strain of Streptomyces aureofacies. The molecule got changed at the C-5 position and was almost devoid of antibiotic activity. Another mutant strain S-604 synthesizes 6-dimethl tetracycline, a new antibiotic, not elaborated by the parent strain, proved to have several advantages. Nowadays it has been one of the leading commercial forms of tetracycline. [49] 
e) minor Mutations: it plays dominant role in strains improvement. By definition, such mutation affects only the amount of product synthesized. Such variants are usually phenotypically similar to the parent, with rapid and abundant mycelial and conidial development. A 10 to $15 \%$ increase in conidial population exposed to moderate does of a mutagen, obtained after repeated isolation of minor (positive) variants and using each succeeding strain for further mutation and selection without the introduction of mutagen in this case, the population to be tested must be large and assay for the desire products. Thus, it must also be accurate and specific. This technique fetched importance in improving P.chrysogenum. For example, Wisconsin series were the famous Q-176 culture with significantly improved antibiotic titers, and strains BL3-D10, which does not produce the characteristic and troublesome Chrysogenin pigment. All further mutants' selections over the next decade were derived from Q-176. [50]

\section{MUTATION CONCEPT FOR STRAIN DEVELOPMENT}

Strains selection as obvious variants after exposure to mutagen are usually inferior in their capacity for accumulation of antibiotic. Improvements are extremely few; their selection and evaluation are extremely important. Mutagen dose is quite important and therefore they sought for major mutation rate are best isolated from populations surviving prolonged dose $\mathrm{s}$ of mutagen, whereas variants for increased productivity are generally isolated from population surviving intermediate dose level. Strain with enhanced altered morphology, may be inherently better producers but may require considerable fermentation development. Step wise selection implies small increment in productivity, the productivity increase and the probability of getting hyper producing strains decrease. Variant strains may acquire special propagation and preservation producers and actual production gains depend also on stability and reliability of performance, though strains may prove better in their productivity at laboratory scale, there is no guarantee that enhance productivity will occur in production fermenters. The long-time pilot plant studies are often necessary before any enhanced strain s potential can be realized in actual production [51].

\section{NUTRIENT SUPPLEMENTS}

The most momentous weapon against any kind of viral infection is a strong immune system. There are plethora of studies done in past that suggest an imperative role of trace elements and vitamins in normal performance of the immune system. Furthermore, there are reports of elevated resistant to viral infection in response to their supplementation. Vitamin D and A ingestion increased the humoral immunity in association with influenza vaccine in pediatric patients. Exogenous supplementation of Se has been shown to affirmatively combat influenza infection in alliance with the vaccination. Apart from this, wide range of herbals, nutraceuticals and probiotics have been found to be effective against viral infestations and stimulation of immune responses [52].

\section{Vitamins}

Vitamin A is an essential fat-soluble vitamin which has a major involvement in regulating vision, growth and maturity as well as protection of the mucosal and epithelium integrity of the human body. It has a crucial participation in elevating the immunomodulatory responses and dogmatic functions in humoral as well as cellular responses. The Vitamin A supplements given to the infants with measles and rabies showed impending improvement (2.1 times) in antibiotic 
response in association with the vaccinations. Vitamin D another fat-soluble vitamin and has a vital role in regulating the adaptive and innate immune responses. More recently, a study carried out by,[53] revealed that supplementation with high dose of vitamin D (2000 IU/day) in contrast to a standard dose (400 IU/day) had no significant effect on the viral infection in the upper respiratory track, however the one third of the population was found to have vitamin D levels less than $30 \mathrm{ng} / \mathrm{ml}$. Similarly, another study suggests vitamin D supplementation with influenza vaccine resulted in enhancement in the levels of TGF- $\beta$ in the plasma which further indicated that vitamin $\mathrm{D}$ directs the lymphocytes polarization towards the tolerogenic immune response. Vitamin D has also been affirmed to demonstrate beneficial effect against other viruses including HCV genotype infection and HCV genotype 2-3 [54]. Another report which suggests antiviral capability of Vitamin D was elucidated by.[55] It was further affirmed that Vitamin D was potent in reducing the hazards associated with viral pandemics. The high dose of Vitamin D reduced the hazard of several chronic ailments such as cardiovascular diseases, diabetes mellitus, hypertension, cancers and respiratory tract infection. Grant and co-workers, additional revealed that vitamin D lowers the risk to respiratory tract infection by sustaining tight junction, decline in the synthesis of pro-inflammatory cytokines and killing the envelope of virus via induction of defensins and cathelicidin. Consequently, the risk of cytokine storm is lowered which prevents pneumonia.

Vitamin $\mathrm{E}$ is also a fat soluble vital and has an antioxidative potential and regulates the host's immune responses. The positive effect of vitamin $\mathrm{E}$ against chronic hepatitis was reported by. [56] They suggested appreciable elevation in normalization of liver enzyme activity and HBVDNA negativitization. Another vitamin that acts as an important antioxidant and enzymatic cofactor is Vitamin C. It acts as a co-factor in varied physiological processes such as hormone synthesis, immune potentiation and collagen synthesis. The meta-analysis role of vitamin $\mathrm{C}$ in treatment and preventions of common cold was carried out by.[57] It was concluded in the view of evidences that vitamin $\mathrm{C}$ mega dose showed reduction in the frequency of common cold in the community. A study conducted by [58] was aimed at elucidating the potential of Curcuma sp., Citrus sp., Alpinia galanga, and Caesalpinia sappan as an anti-SARS-CoV-2 agent via its binding to 3 protein receptors. The protein targets identified were Receptor Binding Domain of spike glycol proteins (RBDS), protease domain of Angiotensin Converting Enzyme-2 PD-ACE2 and SARS-CoV-2 protease by employing molecular docking technique. The result of the study revealed that Citrus sp. had the highest inhibitory potential against SARS-CoV-2, followed by galangal, sappan wood and curcuma species and it was further suggested that they might have antiviral potency against COVID-19. Additionally, different plant-based sources of vitamins include, mushrooms, carrots, broccoli, almonds, citrus, guava, amla, avocados etc. Fig. 4 describes the role of Vitamins (A, C, E and D) in combating COVID-19 


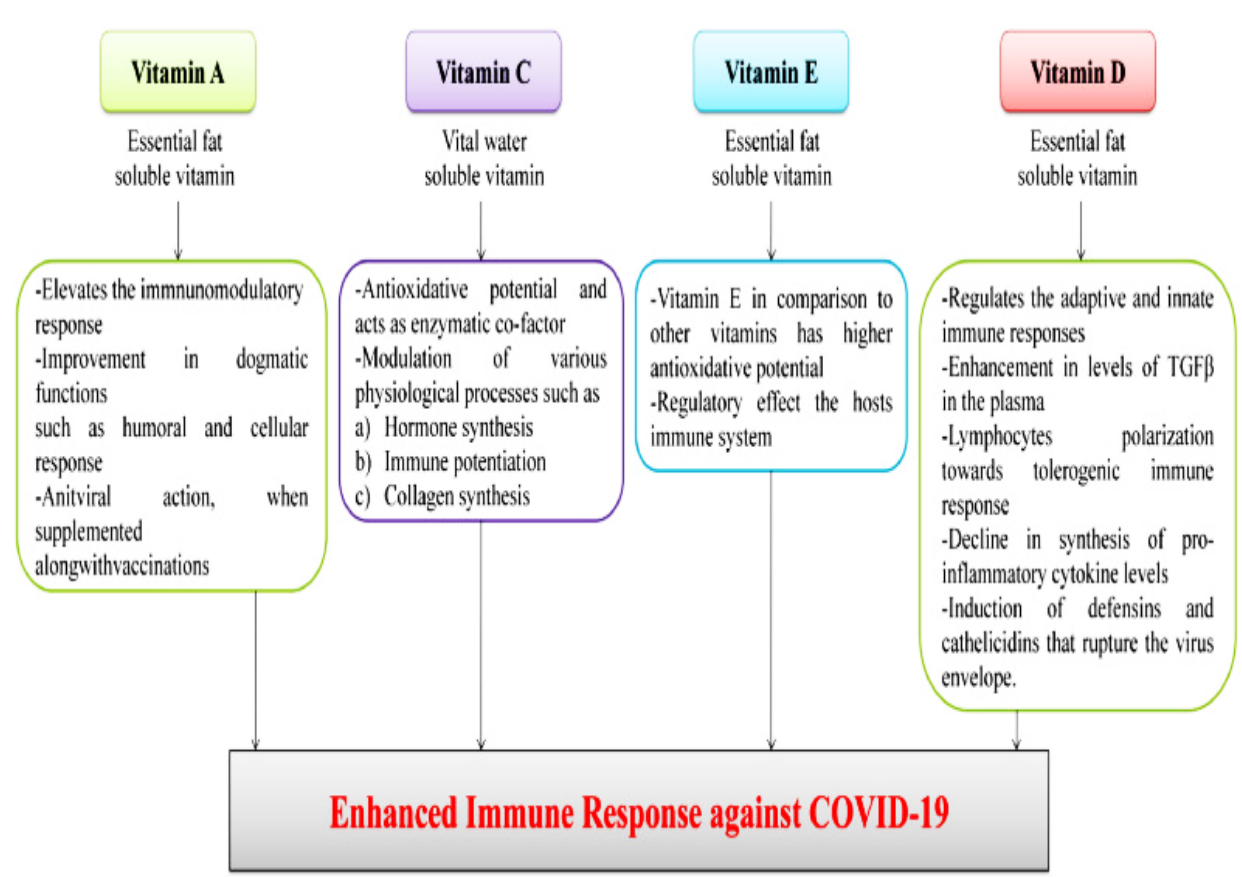

Fig. 4 Role of Vitamins (A, C, E and D) in combating COVID-19.

\section{MATERIALS AND METHOD}

\section{INSTRUMENTS}

Steam pressure cooker (Autoclave), Weighing machine (rove Lectronics) 20 $\mu 1$-micropipette, light microscope (Carzeiss), Hot air oven (kasliwal brothers), Refrigerators (whirlpool GNF 220)

\section{Glass wares, Plastic wares and consumable}

Conical flasks, Beaker, Petri plates, Stirrer, Pipette, Test tube stand, culture tubes, slides, Reagent bottle, cover slips, Forceps Scalpels, Scissors, Wash bottle, Sucker, Gloves, Funnel, Burner tips, Tissue paper, Aluminum foil, filter paper, Test tube, cotton etc., respectively

\section{MEDIA USED}

- Nutrient Agar media(conventional)

- Blood chocolate media (home Base)

- Media for isolation of Bacillus sp, Klebsiella sp, Pseudomonas sp etc. (Home base)

\section{MICROOGANISM ISOLATION AND IDENTIFICATION}

Isolation of bacteria from a mixture of processed cholate blood dry agar medium/ Soya been milk when expose in an ordinary room for three days. samples Serial weakening methods were utilized for the confinement of microscopic organisms. In this procedure test suspension was set up by including the processed blood agar / soya bean milk after blending (1g) was added to 
$10 \mathrm{ml}$ of sterile water (the stock) and shaken overwhelmingly for no less than 1 minute. The weaken was then sedimented for a brief period. Sterile weakening spaces were stamped successively beginning from stock and $10^{-1}$ to $10^{-4}$. One $\mathrm{ml}$ from the stock was exchanged to the 10-1 weakening clear utilizing a crisp sterile pipette. One $\mathrm{ml}$ from the 10-1 weakening was exchanged to the $10^{-2}$ tube for each succeeding stride then from the $10^{-2}$ to the $10^{-3}$, then from the $10^{-3}$ to the $10^{-4}$. From every weakening tube $0.1 \mathrm{ml}$ of weakening liquid was moved into Nutrient Agar society media and hatched at $37{ }^{\circ} \mathrm{C}$ for 24 hours [59]. Ingredient used for the processed of home base medium were as follows: meat extract- $500 \mathrm{ml}$, salt- $10 \mathrm{~g}$, sugar cane molasses- $20 \mathrm{~g}$, soya bean milk and processed blood extract, hydrated organic base $\mathrm{KOH}$ was use for home base $\mathrm{pH}$ adjustment to $\mathrm{pH} 7$ and above. Supplements for conventional media Nutrient agar (NA) society media contained $0.5 \%$ peptone, $0.3 \%$ yeast separate, $0.5 \% \mathrm{NaCl}$, $0.25 \%$ glucose, $1.5 \%$ agar, refined water and $\mathrm{PH}$ was acclimated to 7 at room temperature. After fruitful development of microorganisms as seen in plate 1, 5, 6, 7 and 8 the unadulterated societies of microscopic organisms were sub-refined in NA inclines; hatched at $37{ }^{\circ} \mathrm{C}$ to accomplish enthusiastic development and afterward safeguarded in $20 \%$ glycerol vials at $-80{ }^{\circ} \mathrm{C}$

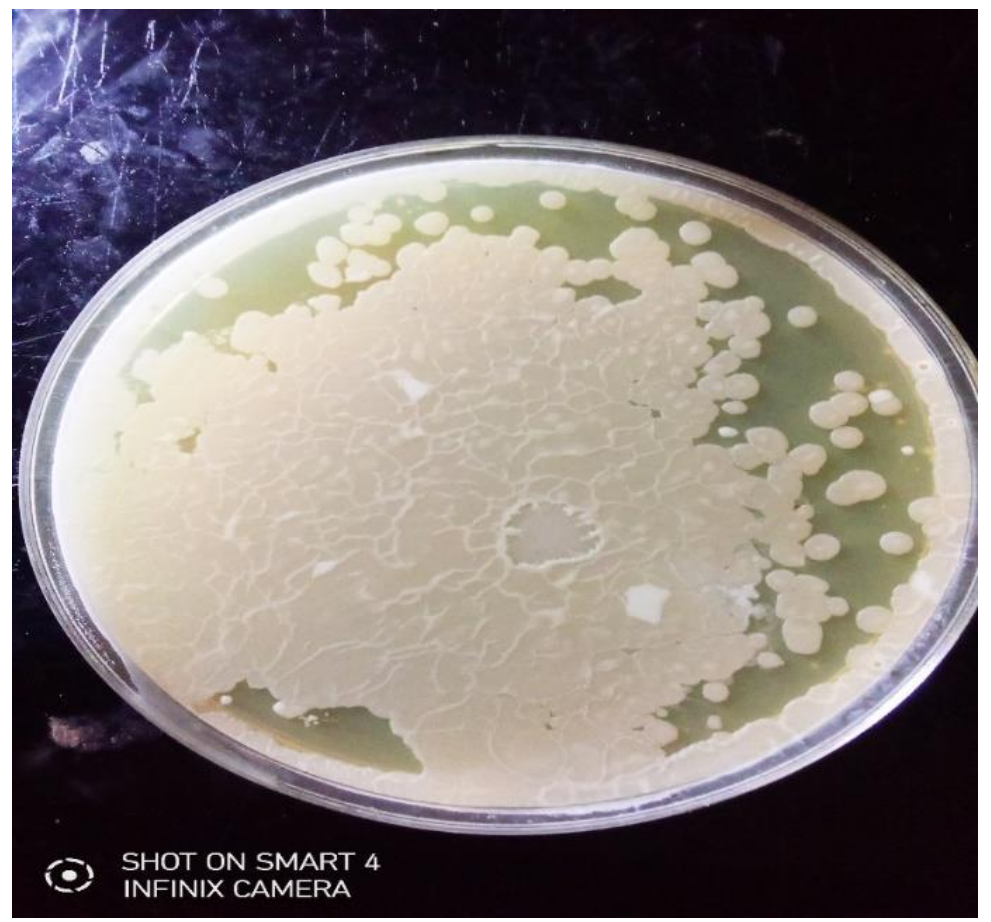

Plate 1. posts mixed culture Bacillus sp and Enterobacter sp

\section{MICROBIOLOGICAL AND BIOCHEMICAL CHARACTERISTIC OF ISOLATED BACTERIA}

Gram stain was performed to watch the cell morphology and gram nature of the microorganisms and biochemical portrayal of the strains were additionally completed. The biochemical tests of Sugar usage; Amino corrosive decarboxylation; Catalase and oxidase creation; Nitrate lessening; Hydrogen sulfide generation; Starch, Casein and Urea hydrolysis; IMVIC tests were performed in-situ [59]. 


\section{MOLECULAR IDENTIFICATION OF PERSISTENT BACTERIA ISOLATES}

\section{DNA isolation Chromosomal DNA}

Available in most bacteria was extracted using DNA isolation kit. Bacteria in liquid broth were grown at a temperature of $37{ }^{\circ} \mathrm{C}$ for $24 \mathrm{~h}$. Bacteria cells were harvested by centrifugation for $10 \mathrm{~min}$ at 6000 Revolution Per Minute (RPM) at room temperature. The supernatant was discarded and the cells re-suspended in $600 \mu$ l buffer $1(50 \mu \mathrm{l}$ Tris $1 \mathrm{M} \mathrm{HCl}(\mathrm{pH} 8.0) 10 \mu \mathrm{l}$ EDTA and $10 \mathrm{~g} / \mathrm{ml}$ RNase). The buffer 1 was transferred to Eppendorf tubes. Six hundred microliters of buffer $2(200 \mu \mathrm{l} 1 \mathrm{M} \mathrm{NaOH} \mathrm{SDS} \mathrm{w/v} \mathrm{pH} \mathrm{8.0)} \mathrm{was} \mathrm{added} \mathrm{to} \mathrm{the} \mathrm{contents} \mathrm{in} \mathrm{the}$ Eppendorf tubes and mixed vigorously ten times in one minute [60]. Chilled buffer 3 placed on ice $(0.5 \mathrm{ml})$ was added and vigorously mixed 10 times at room temperature. The tubes were centrifuged at $6000 \mathrm{rpm}$ for ten minutes. Six hundred and eighty microliter of isopropanol was added to the aspirated supernatant and the mixture incubated at a temperature of $-20{ }^{\circ} \mathrm{C}$ for 20 minutes. Centrifugation was carried out at $6000 \mathrm{rpm}$ for ten minutes and the supernatant discarded to obtain the pellet. The DNA containing pellet was washed with $70 \%(\mathrm{v} / \mathrm{v})$ absolute ethanol and centrifuged at $6000 \mathrm{rpm}$ for ten minutes. The pellet was allowed to dry at room temperature for $20 \mathrm{~min}$ and dissolved in sterile $20 \mu \mathrm{l}$ distilled water. The DNA was stored at a temperature of $-20{ }^{\circ} \mathrm{C}$ for later use [60].

PCR amplification of bacteria DNA Before starting PCR, a $6 \times$ PCR buffer, $2.5 \mu 1$ of dNTP mix, $2.5 \mu 1$ of $25 \mathrm{mM} \mathrm{MgCl}$, primer solutions F27 and $\mathrm{R} 1525$ were thawed at room temperature and placed on ice. A master mix was then prepared as shown in table 2

\section{Restriction Fragment Length Polymorphism (RFLP) analysis}

Restriction enzyme Hae III was used for restriction digestion by premixing $0.5 \mu$ of enzyme with $5.5 \mu \mathrm{l}$ of $10 \times$ buffer. Ten micro liters of mixture were added directly to $30 \mu 1$ of the PCR product and incubated at $30{ }^{\circ} \mathrm{C}$ for $4 \mathrm{~h}$. The digested fragments were resolved in $1.5 \%(\mathrm{v} / \mathrm{v})$ agarose gel in $0.5 \times \mathrm{TBE}$ buffer running at $80 \mathrm{~V}$ for $60 \mathrm{~min}$. Fragment sizes were determined using a $1 \mathrm{~kb}$ sigma and Promega DNA marker. The gel was stained with ethidium bromide and observed with Gel Logic 200 Molecules Imaging System and documented with Kodak Gel Version 4.0 computer software.

\section{MOLECULAR CHARACTERIZATION OF PERSISTENT BACTERIA}

Bacterial DNA quantification and purity determination in objective Five, Bacillus sp, Pseudomonas sp, Klebsiella sp, Shigella sp, and Staphylococcus sp were persistent bacteria after Sodium hypochlorite disinfection. Nucleic acids have an absorption maximum at $260 \mathrm{~nm}$. Most samples contain contaminants such as proteins and single stranded DNA that absorb maximally at $280 \mathrm{~nm}$, the equation A260/A280 is used to calculate DNA in presence of contaminates. Since ratios between 1.7 and 2.0 are acceptable, all the samples examined were considered pure because they were within this range (Table 2). 


\section{SELECTION OF OPTIMAL GROWTH MEDIUM FOR THE SYNTHESIS ALKALINE PROTEINASE FROM BACILLUS SP PSEUDOMONAS SP KLEBSIELLA SP}

\section{Comparative study for fermentation media and culture conditions}

To study the biosynthesis of protein from Bacillus sp Pseudomonas sp and Klebsiella sp two different growth media were used the conventional and home base for alkaline proteinase production were used. The control Medium was used as control while the home base was use as the treated medium. The conventional medium had the following composition $(\mathrm{g} / \mathrm{l})$ : glucose,2.0; Casein, 0.5; peptone, 0.5 yeast extract, $0.5 \operatorname{salt}(\mathrm{v} / \mathrm{v}), 5 \%,\left(\mathrm{MgSO}_{4} .7 \mathrm{H}_{2} \mathrm{O} 5.0\right.$, $\mathrm{KH}_{2} \mathrm{PHO}_{4}$ 5.0, $\mathrm{FeSO}_{4}$. $7 \mathrm{H}_{2} \mathrm{O}$ 0.1) [61]. Home Base Medium (sugar cane molasses, 20g; process soya bean milk $50 \mathrm{ml}$, chocolate blood past $50 \mathrm{ml}$; Sodium Chloride $20 \mathrm{~g}$; processed yeast extract $30 \mathrm{ml}$; meat extract $50 \mathrm{ml}$; processed peptone, as well as all the plants extract/seed contain an appreciable amount of $\mathrm{P}, \mathrm{K}, \mathrm{Mg}, \mathrm{Mn}, \mathrm{Fe} /$ Vitamins). Basal medium containing the synthetic peptone as well as home base peptone alongside with both synthetic yeast extract and home base (each at $1.5 \mathrm{~g} / \mathrm{l}$ level. After autoclaving and cooling the $\mathrm{pH}$ of all the media were adjusted to 7.0 and above by addition of sodium bicarbonate for synthetic basal medium while Hydrated process Organic $\mathrm{KOH} / \mathrm{NaOH}$ for the home base basal medium. Fermentation experiments were set to be carried in 50ml of the above described medium in $250 \mathrm{ml}$ Erlenmeyer flasks. 5\% of an $18 \mathrm{~h}$ old inoculum raised in the basal medium was used to initiate growth. The inoculated flasks were kept on an environmental shaker (New Brunswisk) at 120 $\mathrm{rpm}$ for 12 days at $30^{\circ} \mathrm{C}$. Samples were taken for every $24 \mathrm{~h}$ and was estimated for enzyme activity, soluble protein and growth. All the experiments were carried out in duplicate.

\section{ANTIMICROBIAL ASSAY OF THE CRUDE EXTRACTS:}

The antimicrobial activity was measured by the agar well diffusion method [62]. Sterile nutrient agar was prepared and placed in labelled Petri dishes and allowed to gel. The antibacterial culture was prepared using the test organism on (Nutrient agar/home base nutrient agar). Four wells were bored into the nutrient agar using a $7 \mathrm{~mm}$ sterile corked borer and inoculums containing $10^{5} \mathrm{CFU} / \mathrm{ml}$ of bacteria spread on the solid media with sterile cotton swab moistened with bacterial suspension. Fifty microliters $(50 \mathrm{mg} / \mathrm{ml})$ of essential oils and fractions were dispensed in each well. The dried solvent extracts $(0.2 \mathrm{~g})$ were reconstituted in $2 \mathrm{ml}$ of normal saline and distilled water respectively, to make a stock solution with a 24 concentration of $100 \mathrm{mg} / \mathrm{ml}$. as shown in table 7 plate

\section{SELECTION OF PLANTS AND EXTRACT PREPARATION FOR BIOACTIVITY EVALUATION}

\section{Plant material:}

Twenty-five medicinal plants were employed for the Covid -19 cured but only eight of the plants were used as noted in the research and they are as followed. Radish (Raphanus sativus), Neem leaf ( Azadirachta indica), Moringa leaf( Moringa oleifera), Eucalyptus leaf( Eucalyptus gunnii), Bitter cola( Garcinia Kola), "Bagaruwa" fruit( Acacia nilotica), Tomato(Solnum lycopersicum), Turmeric( Curcuma longa) etc., respectively. Thus, they were collected through purchasing in the market while some were arbitrarily collected from different locations in farm land, Riverine areas as well as bushes free of charge (Kaduna Metropolis) in Kaduna State of Nigeria. 


\section{PREPARATION OF PLANT EXTRACTS;}

Plant parts were collected and wash with water, then dry at room temperature and ground to a fine powder. Aqueous extracts $(1: 10 \mathrm{w} / \mathrm{v})$ were left at room temperature $\left(25-28^{\mathrm{O}} \mathrm{C}\right)$ for $24 \mathrm{~h}$. It was then filtered through 8 layers of muslin cloth and centrifuged at $5000 \mathrm{~g}$ for $10 \mathrm{~min}$. The supernatant was collected. This procedure was repeated twice after which the filtrates were evaporated by a vacuum rotary evaporator to make crude extracts and store at $4^{\circ} \mathrm{C}$ until used.

\section{THE USE OF WATER, ETHANOL, METHANOL, ACETONE}

In phytochemistry Since herbal medicine research aims at identifying bioactive phytocompounds in medicinal plant extracts used by local people to treat diseases based on indigenous knowledge, the solvent chosen must be the same as that used by local communities. Hence, water and ethanol are the commonly used solvents. Water is a universal solvent used to extract plant products with antimicrobial activity and ethanol (at a concentration of 70-96\%) is more effective in isolating bioactive phytocompounds than water. While other solvents were momentarily used so as to ascertain whether they could be tenaciously used for extraction of bioactive compounds as well. Since this study aims at validating indigenous knowledge, water and ethanol extracts were prepared for ethnopharmacological screening. Nearly all identified components from plants active against microorganisms are aromatic and saturated organic compounds, and are most often obtained through ethanol and water extraction [63].

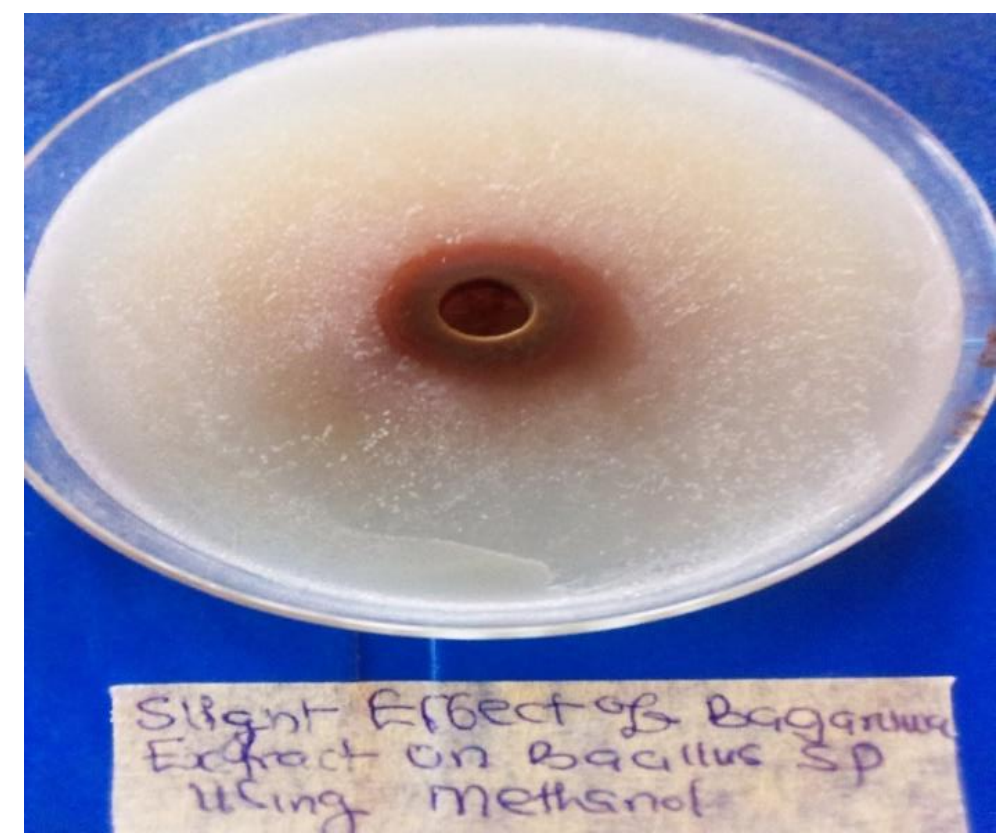

Plate 2: posted the effect of Bagaruwa extract on Bacillus sp using methanol

\section{PHYTOCHEMICAL SCREENING:}

Major phytoconstituents in the test plant extract such as alkaloids, saponins, Tannin, steroids, flavonoids, glycosides, terpenoids anthraquinone etc., qualitative phytochemical analysis The bioactive constituents present in different solvent extracts was qualitatively analyzed following standard procedures as described by Harborne, Treasa and Evans1 and Sofowara[64-. 68] 


\section{Test for Saponin}

Methodology is as reported by [64]. Distilled water $\left(30 \mathrm{~cm}^{3}\right)$ was added to the plants extract samples $(0.30 \mathrm{~g})$ and boiled for 10 minutes in water bath and filtered using Whatman filter paper number $42(125 \mathrm{~mm})$. A mixture of distilled water $\left(5 \mathrm{~cm}^{3}\right)$ and filtrate $\left(10 \mathrm{~cm}^{3}\right)$ was agitated vigorously for a stable persistent froth. The formation of emulsion on addition of three drops of olive oil showed positive result.

\section{Test for Steroid}

Analytical method used is according to [65]. Each sample $(0.30 \mathrm{~g})$ weighed into a beaker was mixed with $20 \mathrm{~cm}^{3}$ of ethanol; the component was extracted for 2 hours. To the ethanolic extract of each sample $\left(5 \mathrm{~cm}^{3}\right)$ was added $2 \mathrm{~cm}^{3}$ acetic anhydride followed with $2 \mathrm{~cm}^{3}$ of concentrated tetra-oxosulphate (VI) acid. A violet to blue or green color change in sample(s) indicates the presence of steroids.

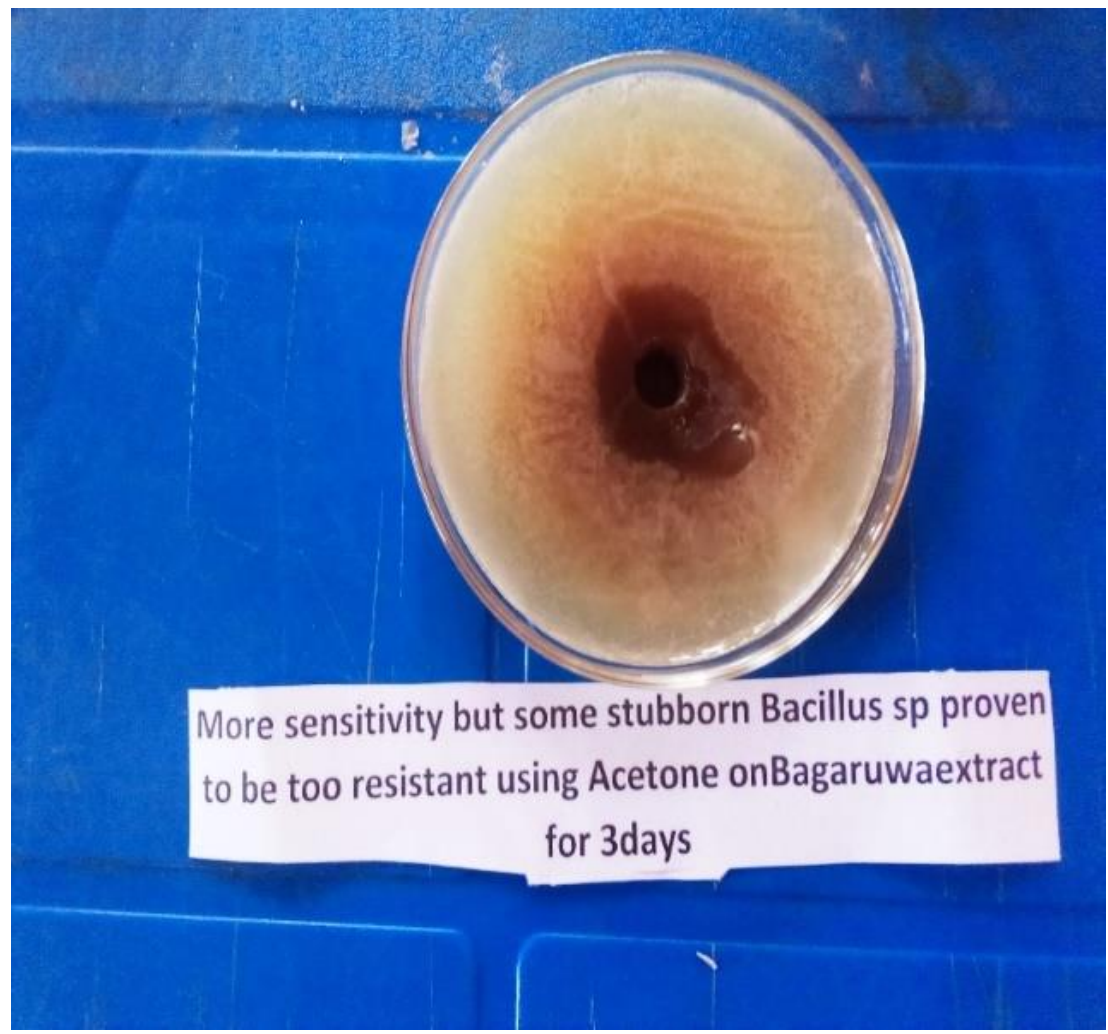

Plate 3 : Post the susceptibility of Bacillus sp on "Bagaruwa" extract using Acetone

\section{Test for Terpenoids}

Methodology is as reported by [65]. Each of the plant extract sample (5ml) was introduce into a beaker and extracted with $30 \mathrm{~cm}^{3}$ and component extracted for 2 hours. A mixture of chloroform $\left(2 \mathrm{~cm}^{3}\right)$ and concentrated tetra-oxosulphate (VI) acid $\left(3 \mathrm{~cm}^{3}\right)$ was added to $5 \mathrm{~cm}^{3}$ of each extract to form a layer. The presence of a reddish-brown coloration at the interface shows positive results for the presence of terpenoids. 


\section{Test for Flavonoids}

The test for flavonoid adopted is as reported by [66]. Each sample $(0.30 \mathrm{~g})$ weighed into a beaker was extracted with $30 \mathrm{~cm}^{3}$ of distilled water for 2 hours and filtered with Whatman filter paper number $42(125 \mathrm{~mm})$. To $10 \mathrm{~cm}^{3}$ of the aqueous filtrate of each wood extract was added $5 \mathrm{~cm}^{3}$ of $1.0 \mathrm{M}$ dilute ammonia solution followed by the addition of $5 \mathrm{~cm}^{3}$ of concentrated tetraoxosulphate (VI) acid. Appearance of yellow coloration which disappeared on standing shows the presence of flavonoids.

\section{Test for Alkaloids}

Test for alkaloids: A total of $0.5 \mathrm{~g}$ each of the shoot and root powder of plants was mixed with methanol containing $1 \% \mathrm{HCl}$, and then boiled and filtered. A total of $2 \mathrm{ml}$ of $10 \%$ ammonia and $5 \mathrm{ml}$ of chloroform was added to $5 \mathrm{ml}$ of the filtrates and shaken gently to extract the alkaloidal base. The chloroform layer was extracted with $2 \mathrm{ml}$ of acetic acid, and Mayer's reagent was added. The formation of cream (with Mayer's reagent) or presence of turbidity was regarded as the presence of alkaloids. [ 65]

\section{Test for Glycoside}

Glycoside test was conducted according to the method reported by [66]. To $2.00 \mathrm{~g}$ of each sample was added $20 \mathrm{~cm}^{3}$ of water, heated for 5 minutes on a water bath and filtered through Gem filter paper $(12.5 \mathrm{~cm})$. The following tests were carried out with the filtrate:(a) $0.2 \mathrm{~cm}^{3}$ of Fehling's solutions A and B was mixed with $5 \mathrm{~cm}^{3}$ of the filtrate until it became alkaline (tested with litmus paper). A brick-red coloration on heating showed a positive result. (b)Instead of water, $15 \mathrm{~cm}^{3}$ of $1.0 \mathrm{M}$ sulphuric acid was used to repeat the above test and the quantity of precipitate obtained compared with that of (a) above. High precipitate content indicates the presence of glycoside while low content shows the absence of glycoside.

\section{Test for anthraquinone}

About $0.5 \mathrm{~g}$ of the shoot extract was taken into a dry test tube and $5 \mathrm{ml}$ of chloroform was added and shaken for $5 \mathrm{~min}$. The extract was filtered and the filtrate was shaken with an equal volume of $10 \%$ ammonia solution. A pink violet or red color in the ammonia layer was observed which indicative the presence of anthraquinones [67].

\section{Test for Tannins:}

Water extracts of plant shoots were treated with $15 \%$ ferric chloride test solution. A blue color in the mixtures signified the presence of hydrolysable tannin. For confirmation, $0.5 \mathrm{~g}$ of the extracts were added to $10 \mathrm{~mL}$ of freshly prepared potassium hydroxide $(\mathrm{KOH})$ in a beaker, and shaken to dissolve. A dirty precipitate was indicative the presence of tannin 12[68]

\section{QUANTITATIVE ESTIMATION OF SECONDARY METABOLITES}

The presence of secondary metabolites from the leaves, roots and stem bark of the test plants were quantitatively determined by adopting standard protocols 


\section{Determination of alkaloids}

Quantitative determination of alkaloid was according to the methodology by [69]. Exactly $200 \mathrm{~cm}^{3}$ of $10 \%$ acetic acid in ethanol was added to each wood powder sample $(2.50 \mathrm{~g})$ in a $250 \mathrm{~cm}^{3}$ beaker and allowed to stand for 4 hours. The extract was concentrated on a water bath to one-quarter of the original volume followed by addition of 15 drops of concentrated ammonium hydroxide dropwise to the extract until the precipitation was complete immediately after filtration. After 3 hours of mixture sedimentation, the supernatant was discarded and the precipitates were washed with $20 \mathrm{~cm}^{3}$ of $0.1 \mathrm{M}$ of ammonium hydroxide and then filtered using Gem filter paper $(12.5 \mathrm{~cm})$. Using electronic weighing balance Model B-218, the residue was dried in an oven and the percentage of alkaloid is expressed mathematically as

\section{\%Alkaloid $=\underline{\text { Weight of Alkaloids } \quad X \quad 100}$}

\section{Weight of the sample}

\section{Determination of flavonoid}

Flavonoid determination was by the method reported by [70]. Exactly $50 \mathrm{~cm}^{3}$ of $80 \%$ aqueous methanol added was added to $2.50 \mathrm{~g}$ of sample in a $250 \mathrm{~cm}^{3}$ beaker, covered, and allowed to stand for 24 hours at room temperature. After discarding the supernatant, the residue was reextracted (three times) with the same volume of ethanol. Whatman filter paper number 42 $(125 \mathrm{~mm})$ was used to filter whole solution of each wood sample. Each wood sample filtrate was later transferred into a crucible and evaporated to dryness over a water bath. The content in the crucible was cooled in a desiccator and weighed until constant weight was obtained. The percentage of flavonoid was calculated as

\section{\% Flavonoid $=\underline{\text { Weight of Alkaloids } X \mathbf{1 0 0}}$}

\section{Weight of the sample}

\section{Determination of saponin}

Saponin quantitative determination was carried out using the method reported by [70]. Exactly $100 \mathrm{~cm}^{3}$ of $20 \%$ aqueous ethanol was added to 5 grams of each wood powder sample in a $250 \mathrm{~cm}^{3}$ conical flask. The mixture was heated over a hot water bath for 4 hours with continuous stirring at a temperature of $55^{\circ} \mathrm{C}$. The residue of the mixture was reextracted with another $100 \mathrm{~cm}^{3}$ of $20 \%$ aqueous ethanol after filtration and heated for 4 hours at a constant temperature of $55^{\circ} \mathrm{C}$ with constant stirring. The combined extract was evaporated to $40 \mathrm{~cm}^{3}$ over water bath at $90^{\circ} \mathrm{C} .20 \mathrm{~cm}^{3}$ of diethyl ether was added to the concentrate in a $250 \mathrm{~cm}^{3}$ separator funnel and vigorously agitated from which the aqueous layer was recovered while the ether layer was discarded. This purification process was repeated twice. $60 \mathrm{~cm}^{3}$ of nbutanol was added and extracted twice with $10 \mathrm{~cm}^{3}$ of $5 \%$ sodium chloride. After discarding the sodium chloride layer, the remaining solution was heated in a water bath for 30 minutes, after which the solution was transferred into a crucible and was dried in an oven to a constant weight. The saponin content was calculated as a percentage: 
\%Flavonoid $=\underline{\text { Weight of Alkaloids } \quad X \quad 100}$

\section{Weight of the sample}

\section{Determination of tannins}

Analytical method for quantitative determination of tannin was according to [71]. By dissolving $50 \mathrm{~g}$ of sodium tungstate $\left(\mathrm{Na}_{2} \mathrm{WO}_{4}\right)$ in $37 \mathrm{~cm}^{3}$ of distilled water, Folin-Denis's reagent was made. To the reagent prepared above, $10 \mathrm{~g}$ of phosphomolybdic acid $\left(\mathrm{H}_{3} \mathrm{PMo}_{12} \mathrm{O}_{40}\right)$ and $25 \mathrm{~cm}^{3}$ of orthophosphoric acid $\left(\mathrm{H}_{3} \mathrm{PO}_{4}\right)$ were added. Two-hour reflux of the mixture was carried out, cooled, and diluted to $500 \mathrm{~cm}^{3}$ with distilled water. One gram of each wood powder (sample) in a conical flask was added to $100 \mathrm{~cm}^{3}$ of distilled water. This was boiled gently for 1 hour on an electric hot plate and filtered using number $42(125 \mathrm{~mm})$ Whatman filter paper in a $100 \mathrm{~cm}^{3}$ volumetric flask. Addition of $5.0 \mathrm{~cm}^{3}$ Folin-Denis reagent and $10 \mathrm{~cm}^{3}$ of saturated $\mathrm{Na}_{2} \mathrm{CO}_{3}$ solution into $50 \mathrm{~cm}^{3}$ of distilled water and $10 \mathrm{~cm}^{3}$ of diluted extract (aliquot volume) was carried out after being pipetted into a $100 \mathrm{~cm}^{3}$ conical flask for colour development. The solution was allowed to stand for 30 minutes in a water bath at a temperature of $25^{\circ} \mathrm{C}$ after thorough agitation. With the aid of a Spectrum Lab 23A spectrophotometer optical density was measured at $700 \mathrm{~nm}$ and compared on a standard tannic acid curve. Dissolution of $0.20 \mathrm{~g}$ of tannic acid in distilled water and dilution to $200 \mathrm{~cm}^{3}$ mark $\left(1 \mathrm{mg} / \mathrm{cm}^{3}\right)$ were used to obtain tannic standard curve. Varying concentrations $(0.2-$ $1.0 \mathrm{mg} / \mathrm{cm}^{3}$ ) of the standard tannic acid solution were pipetted into five different test tubes to which Folin-Denis's reagent $\left(5 \mathrm{~cm}^{3}\right)$ and saturated $\mathrm{Na}_{2} \mathrm{CO}_{3}\left(10 \mathrm{~cm}^{3}\right)$ solution were added and made up to the $100 \mathrm{~cm}^{3}$ mark with distilled water. The solution was left to stand for 30 minutes in a water bath at $25^{\circ} \mathrm{C}$. Optical density was ascertained at $700 \mathrm{~nm}$ with the aid of a Spectrum Lab 23A spectrophotometer. Optical density (absorbance) versus tannic acid concentration was plotted.

The following formula was used in the calculation:

\section{Tannic acid ( $\underline{\mathrm{mg}}) \quad=\underline{\mathrm{C} \times \text { Volume } \mathrm{x} 100}$}

100 Aliquot Volume $x$ weight of sample

\section{Test for Terpenoids}

Dried plant extract 10 gram (Wi) was taken and soaked in $90 \mathrm{ml}$ of ethanol). The extract after filtration was mixed with $10 \mathrm{ml}$ of petroleum ether and again filtrated using separating funnel. The extract was waited for its complete drying and measurement is taken (Wf). The yield (\%) of total terpenoids contents was measured by the formula:

$$
\text { Total terpenoids }=\underline{W i-W f} \times 100
$$


Where, $\mathrm{Wi}=$ dried plant extracts,

$\mathrm{Wf}=$ extracts after drying

\section{Glycoside:}

Determination of Cardiac glycosides: Cardiac glycoside content in the sample was evaluated using Buljet's reagent as described by [72] $.1 \mathrm{~g} / 50 \mathrm{ml}$ of the fine powder/ filtrate of Senecio biafrae leaves was soaked in $10 \mathrm{ml}$ of $70 \%$ alcohol for $2 \mathrm{hrs}$. and then filtered. The extract obtained was then purified using lead acetate and Na2HPO4 solution before the addition of freshly prepared Buljet's reagent (containing $95 \mathrm{ml}$ aqueous picric acid $+5 \mathrm{ml} 10 \%$ aqueous $\mathrm{NaOH}$ ). The difference between the intensity of colors of the experimental and blank (distilled water and Buljet's reagent) samples gives the absorbance and is proportional to the concentration of the glycosides.

The following formular was used in the calculation

$\%$ Inhibition $=(\underline{\text { abs of the test control }- \text { Abs of the test solution } X 100)}$

\section{Abs of control}

\section{Total anthraquinone glycosides}

Quantitative Analysis of Total Anthraquinone Glycosides 12; the extract (1.00 g) was accurately weighed and distilled water $(30 \mathrm{ml})$ was added. The mixture was mixed, weighed and refluxed on a water bath for 15 minutes. The flask was allowed to cool, weighed, adjusted to the original weight with water and the mixture was centrifuged at $4000 \mathrm{rpm}$ for 10 minutes. Twenty milliliter of the supernatant liquid was transferred to a separatory funnel and acidified with $2 \mathrm{M}$ hydrochloric acid. Fifteen milliliter of chloroform was added, the mixture was extracted and the chloroform layer was discarded. The extraction was done triplicate. The aqueous layer was separated and $0.10 \mathrm{~g}$ of sodium bicarbonate was added. The mixture was then shaken for 3 minutes and centrifuged at $4000 \mathrm{rpm}$ for another 10 minutes. Ten milliliter of the supernatant liquid was transferred to a $100 \mathrm{ml}$ flask. The solution of $10.5 \% \mathrm{w} / \mathrm{v}$ ferric chloride hexahydrate $(20 \mathrm{ml})$ was added and mixed. The mixture was refluxed on a boiling water bath for 20 minutes. Concentrated hydrochloric acid $(1 \mathrm{ml})$ was added and the mixture was heated for 20 minutes, with frequently shaking to dissolve the precipitate. The mixture was cooled, transferred to a separatory funnel and shaken with $25 \mathrm{ml}$ diethyl ether. The partition was repeated until anthraquinones were exhaustively extracted, tested by the Borntrager's reaction. The diethyl ether extracts were combined and washed with $15 \mathrm{ml}$ distilled water twice. The combined diethyl ether was then transferred to a $100 \mathrm{ml}$ volumetric flask and adjusted to volume. Twenty-five milliliter of the solution was evaporated to dryness. The residue was dissolved with $10 \mathrm{ml}$ of $0.5 \% \mathrm{w} / \mathrm{v}$ magnesium acetate in methanol yielding a red solution. The UV absorbance was measured at $515 \mathrm{~nm}$.[73]

The following formular was used in the calculation

\section{\% Inhibition $=(\underline{\text { abs of the test control }- \text { Abs of the test solution } X 100)}$}

Abs of control 


\section{DETERMINATION OF FERMENTED PROPERTIES OF SECONDARY METABOLITES}

\section{Theory.}

$\mathrm{pH}$ is defined as the negative logarithm to the base 10 of $\mathrm{H}^{+}$ion activity or concentration $\mathrm{pH}=-\log 10 \mathrm{H}^{+}=\log 101 / \mathrm{H}^{+}$(Activity) fermented secondary metabolite's reaction or $\mathrm{pH}$ is meant to express the acidity or alkalinity of the fermented microbial extract. It is very important property of the fermented secondary metabolites because it determines the capacity for the microbial growth absorbility of nutrient, bacterial activity and the physical condition of the fermented secondary metabolite growth

\section{pH}

Twenty-five $\mathrm{ml}$ of the fermented secondary metabolites was pipetted into $50 \mathrm{ml}$ of a beaker, and $20 \mathrm{ml}$ of reagent water was added after which it was then covered, and the suspended solution was continuously stirred for 5 minutes. This was then allowed to stand for about one hour so that the suspended clag or filter/centrifuged of the aqueous phase $\mathrm{pH}$ was measured. The electrode in the clamps of the electrode's holder was adjusted down into the beaker. The glass electrode was immersed just deep enough into the clear supernatant solution to establish a good electrical contact through the ground glass and was read on the $\mathrm{pH}$ meter [74].

\section{Acidity}

One hundred $\mathrm{ml}$ of the sample was introduced in an Erlenmeyer flask with three drops of phenolphthalein indicator. The solution was then titrated with $0.024 \mathrm{NaOH}$ from a burette until the first permanent pink colour appeared and the 00 of sodium hydroxide used was recorded

\section{Calculation}

\section{Millilitre of $0.02 \mathrm{~N} \mathrm{NaOH} \times 10=\mathrm{mg} / \mathrm{L}$ total acidity expressed as $\mathrm{CaCO}_{3}$ [75]. Alkalinity}

One hundred $\mathrm{ml}$ of the sample was introduced into a 25000 Erlenmeyer flask followed by addition of three drops of phenolphthalein indicator to it. Upon the development of a pink color $0.02 \mathrm{~N}$ sulphuric acid from a burette was added until the pink color just disappears and the amount of acid used (00) was recorded. Three drops of methyl orange indicator was then added to the flask. If the sample became yellow, then $0.02 \mathrm{~N}$ Sulphuric acid was added until the difference in color was noted when compared with the distilled water. The alkalinity was calculated using:

Total alkalinity as $\mathrm{CaCO}_{3}(\mathrm{mg} / \mathrm{L})=$ Total $\mathrm{ml}$ acid $\mathrm{x} 10$ [76].

\section{Total Nitrogen}

$50 \mathrm{ml}$ of the fermented sample was poured into $300 \mathrm{ml}$ kjeldahl flask along with $25 \mathrm{ml}$ of conc. $\mathrm{H}_{2} \mathrm{SO}_{4}$ and $3 \mathrm{~g}$ mixed catalyst. The sample was digested using Kjeldahl digestion apparatus until a clear green or whitish color was obtained. The digested solution was then diluted to 100 $\mathrm{ml}$ with distilled water. Distillation was done by adding $20 \mathrm{ml}$ of diluted digest into $500 \mathrm{ml}$ kjeldahl flask containing anti-bumping chips and $40 \mathrm{ml}$ of $40 \% \mathrm{NaOH}$ was slowly added by 
the side of the flask. A conical flask $250 \mathrm{ml}$ ) containing a mixture of $50 \mathrm{ml}$ of $2 \%$ boric acid and 4 drops of mixed indicator (cresol/bromothymol) was used to trap the liberated ammonia. The distillate was then titrated with 0.IM Hel. The total nitrogen content was then calculated using

\section{Calculation}

$\% \mathrm{~N}_{2}=\underline{14 \times \mathrm{M} \times \mathrm{Vt} \times \mathrm{V}} \times 100$

Weight of Sample (mg) x Vs

Where $\mathrm{M}=$ actual molarity of acid

$\mathrm{V}=$ titre volume of $\mathrm{HCI}$ used

$\mathrm{V} \mathrm{t}=$ total volume of diluted digest

Vs = aliquot volume distilled [77].

\section{Phosphorus}

Fifty $\mathrm{ml}$ of the fermented plant extract sample was filtered through a nylon cloth into a glass beaker. Twenty-five $\mathrm{ml}$ of the filtrate was heated for 25 minutes with $\mathrm{HN} 03 / \mathrm{HCI}$ in a ratio of 3: 1 (digestion). The mixture was diluted to the $100 \mathrm{ml}$ mark with distilled water. Fifteen $\mathrm{ml}$ of the diluted solution was then pipetted into a cuvette and I $\mathrm{ml}$ of the phosphate reagent was added to it and the mixture was shaken vigorously and the reading taken using the phosphate meter [78].

\section{QUANTITATIVE ANALYSES OF MINERALS PRESENCE IN FERMENTED COVID -19 THERAPY}

\section{Potassium}

To determine the potassium content of the mixed extract sample, $100 \mathrm{ml}$ of the mixture was introduced in $50 \mathrm{ml}$ of distilled water and filtered using nylon cloth. The filtrate $(25 \mathrm{ml})$ was mixed with $\mathrm{HNO}: \mathrm{HCIO}_{4}$ in a 2: I ratio. The beaker containing the mixture was then placed on a hot plate and boiled until the solution became clear. This was then filtered using Whatman filter paper No. I in a volumetric flask and the volume of the filtrate was made up to $100 \mathrm{ml}$ by the addition of deionized water. Digested sample was stored in a sterile polyethylene bottle at room temperature for further analysis of the metal using atomic absorption Spectrophotometer

Obtained from NARICT,2006.

\section{Calculation}

$\%$ Potassium $=R \times 0.005$

Where $\mathrm{R}=$ Potassium concentration $(\mathrm{ppm})$ in the aliquot 


\section{ZINC, CUPPER, MANGANASE AND IRON}

\section{THEORY}

The chelating agents combine with free metal atom in solution to form complexes. DTPA (Diethlene trianminepenta acetic acid) offers the most favorable combination of stability constants for the simultaneous complexing of $\mathrm{Zn}, \mathrm{Cu}, \mathrm{Mn}$, and $\mathrm{Fe}$

Materials required

(i) DTPA 0.05M

(ii) $\mathrm{CaCl} 2,2 \mathrm{H} 2 \mathrm{O} 0.01$

(iii) TEA o.1 (Triethanol amine)

Extracting Solution. $13.1 \mathrm{ml}$ reagent grade TEA, $1.967 \mathrm{~g}$ DTPA (AR Grade) and $0.5 \mathrm{~g}$ of $\mathrm{CaCl} 2$ were Dissolved in $100 \mathrm{ml}$ of distilled water. The solution was allowed to settle for some time so as the DTPA could be allow to dissolved and dilute to approximately $900 \mathrm{ml}$. The $\mathrm{pH}$ was adjusted to 7.3 with 1:1 HCL while stirring and dilute it to 1 liter.

Standard Solution. Zinc standard solution: $0.439 \mathrm{~g}$ AR grade $\mathrm{ZnSO} 4.7 \mathrm{H} 2 \mathrm{O}$ was dissolved in $200 \mathrm{ml}$ distilled water in a beaker. $5 \mathrm{ml}$ of $1 \mathrm{NH} 2 \mathrm{SO} 4$ was as well added in the solution and was transferred to a liter- measuring flask. Thus, the volume was then marked by distilled water for a standard solution of 100ppm in-situ. $10 \mathrm{ml}$ of this standard solution was dully Transferred to $100 \mathrm{ml}$ volumetric flask which was then diluted to the mark with DTPA extracting solution for a stock solution of $100 \mathrm{ppm}$. For the preparation of working standards solution and, transfer $1,2,4$ and $6 \mathrm{ml}$ of stock solution (10ppm).

$\begin{array}{lllllll}\text { Volume of stock Zn solution taken: } & 0 & 1 & 2 & 4 & 6 & \mathrm{ml}\end{array}$

Conc. Of Zn now in solution: $\quad \begin{array}{llllll}0 & 0.1 & 0.2 & 0.4 & 0.6(\mathrm{ppm})\end{array}$

Iron Standard Solution: $\quad 0.702 \mathrm{~g}$ of AR grade ammonium ferrous sulphate was poured in $300 \mathrm{ml}$ distilled water in a beaker after which $5 \mathrm{ml} \mathrm{1:} 5 \mathrm{H} 2 \mathrm{SO} 4$ was added to the solution. the solution was later transferred to a flask of 1 liter capacity and make volume to the mark. This made a standard solution of $100 \mathrm{ppm}$ in-situ. A working standard was prepared and transferred $1,2,4$ and $6 \mathrm{ml}$ of stock solution and dilute each to the mark with DTPA extracting solution volume of stock Fe solution

$\begin{array}{lllllll}\text { Volume of stock Fe solution taken: } & 0 & 1 & 2 & 4 & 6 & \mathrm{ml}\end{array}$

$\begin{array}{lllllll}\text { Conc. Of Fe now in solution: } & 0 & 0.1 & 0.2 & 0.4 & 0.6 & (\mathrm{ppm})\end{array}$

[80] 
Manganese Standard Solution: $0.288 \mathrm{~g}$ potassium permanganate was introduced in $300 \mathrm{ml}$ distilled water in a beaker after which $20 \mathrm{ml}$ conc. $\mathrm{H} 2 \mathrm{SO} 4$ was then allowed to warm in water bath to about $60^{\circ} \mathrm{C}$. Thus, oxalic acid solution was subsequently added drop wise to make the solution colorless. The Cooling solution was then transferred to a 1-liter flask and make volume to work. This made an equivalent of $100 \mathrm{ppm} \mathrm{Mn} \mathrm{solution.} \mathrm{A} \mathrm{working} \mathrm{standard}$ solution was circumspectly allowed by, transferring 1,2, 4, 6 and $8 \mathrm{ml}$ of the standard solution to series of $100 \mathrm{ml}$ volumetric flask and dilute each to the mark with DTPA extracting solution.

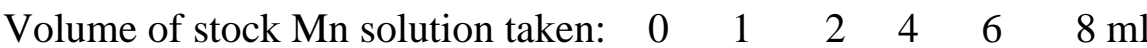

Conc. Of Mn now in solution: $\quad \begin{array}{llllll}0 & 0.1 & 0.2 & 0.4 & 0.6 & 8(\mathrm{ppm})\end{array}$

\section{Copper Standard Solution:}

$0.392 \mathrm{~g}$ copper sulphate in $400 \mathrm{ml}$ distilled water in a beaker was transfer to a little flask, and make volume to mark with distilled water. This standard solution containing $100 \mathrm{ppm} \mathrm{Cu}$ insitu. A working standard solution was transfer 1, 2, 4 and $6 \mathrm{ml}$ of stock solution to a series of clean $100 \mathrm{ml}$ volumetric flasks and dilute each to the mark with DTPA extracting solution.

$\begin{array}{lcccccc}\text { Volume of stock } \mathrm{Cu} \text { solution taken: } & 0 & 1 & 2 & 4 & 6 & \mathrm{ml} \\ \text { Conc. Of } \mathrm{Cu} \text { now in solution: } & 0 & 0.1 & 0.2 & 0.4 & 0.6 & (\mathrm{ppm})\end{array}$

\section{Procedure}

At least 3-4 standards and a blank of each micronutrient cation are used for drawing a calibration curve. The blank solution $0(\mathrm{ppm})$ is used to zero the atomic absorption spectrometer. The standards are then analyzed with the lowest concentration first, and the blank run between standards to ensure that the line (Zero point) has not changed. A graph of absorbance vs. Concentration of standard solution was plotted on a graph paper. After setting the instrument aspirate the sample, was read by absorbance, thus the concentration against absorbance from the curve was accentuated. $100 \mathrm{ml}$ of the fermented secondary metabolites extract was assiduously introduced into $250 \mathrm{ml}$ Erlenmeyer conical flask, after which $20 \mathrm{ml}$ of DTPA extracting solution follows in-situ. The solution in the flask was tightly corked and shook for 2 hours with speed of 120cycles per minute. Further Filtrates in polypropylene bottle were then analyzed for the respective micronutrients in their sequence ( $\mathrm{Zn}, \mathrm{Cu}, \mathrm{Mn}, \mathrm{Fe}$,) using atomic absorption spectrophotometer. [80]

\section{QUALITATIVE ANALYSIS OF VITAMINS PRESENT IN FERMENTED COVID- 19 THERAPY}

Test for Vitamin - A In $5 \mathrm{ml}$ of chloroform, 250mg of the powdered sample was dissolved and filtered in-situ. On to the filtrate, $5 \mathrm{ml}$ of antimony trichloride solution is added. The appearance of transient blue color indicates presence of vitamin- A [81]

A Test for vitamin - C In $5 \mathrm{ml}$ of distilled water, $1 \mathrm{ml}$ of the sample was diluted and a drop of $5 \%$ sodium nitroprusside and $2 \mathrm{ml}$ of $\mathrm{NaOH}$ was added. Few drops of $\mathrm{HCl}$ were likewise added dropwise, the yellow color turns blue. This indicates the presence of vitamin- C 
Test for vitamin - D In $10 \mathrm{ml}$ of chloroform, $50 \mathrm{mg} / 50 \mathrm{ml}$ of powdered/liquid extract was carefully dissolved and filtered as usual. $10 \mathrm{ml}$ of antimony trichloride was then added, the appearance of pinkish-red color indicates the presence of vitamin - D

Test for vitamin $-\mathbf{E}$ the extract of the sample was made and filtered (500mg in $10 \mathrm{ml})$, few drops of $0.1 \%$ ferric chloride were added and $1 \mathrm{ml}$ of $0.25 \%$ of 2 ' - 2 'dipyridyl was added to $1 \mathrm{ml}$ of the filtrate. Bright-red color was formed with a white background.

\section{CELL BIOMASS DETERMINATION (DRY WEIGHT)}

Following the methods used by [82] after completion of fermentation, the fermentation broth in each was filtered, the suspension in each flask were centrifuged at $5000 \mathrm{rpm}$ for 10 minutes several times with intermittent washing with cold distilled water. Each biomass was dried in an oven at $60^{\circ} \mathrm{C}$ to constant weight. Dry weight of biomass cell was measured using Methler balance (Scaltee).

\section{RESULTS AND DISCUSSIONS}

\section{ISOLATION AND SELECTION OF PROTEASE DEGRADING ANTIOXIDANT (PLANTS EXTRACT) PRODUCING STRAINS}

The purpose of isolation protease degrading antioxidant microorganisms in this study was to evacuate and identify the performance of various bacteria with the highest capacity to producing drugs recovery like those of, HIV/AIDS, covid 19, Cancer, diabetes etc., respectively through both submerge and solid-state fermentation. In quantum mannerism, most of these antioxidant's presence (From different plants extract) degrading bacteria usually contributed immensely to producing high amounts of fermented products which are invariably synthesized by microorganisms in-situ. Prior to the stage of this research, isolation and selection of antioxidant degrading microbes from different plants extract have been a welcoming idea and well documented for alkalophilic( $\mathrm{pH} 7-8)$ adaptation for high growth in well enrich medium. During this study, isolation and identification of microorganisms that have been exposed to 3 days protease degraders in milk and blood paste have there been a normal routine for degrading microbial growth in solid and liquid medium. Thus, these degrading microbes have played a significant role in degrading highly toxic plant extract properties to minimal range for drugs recovery with respect to antiviral lethal properties in human system for safety (biosafety) 


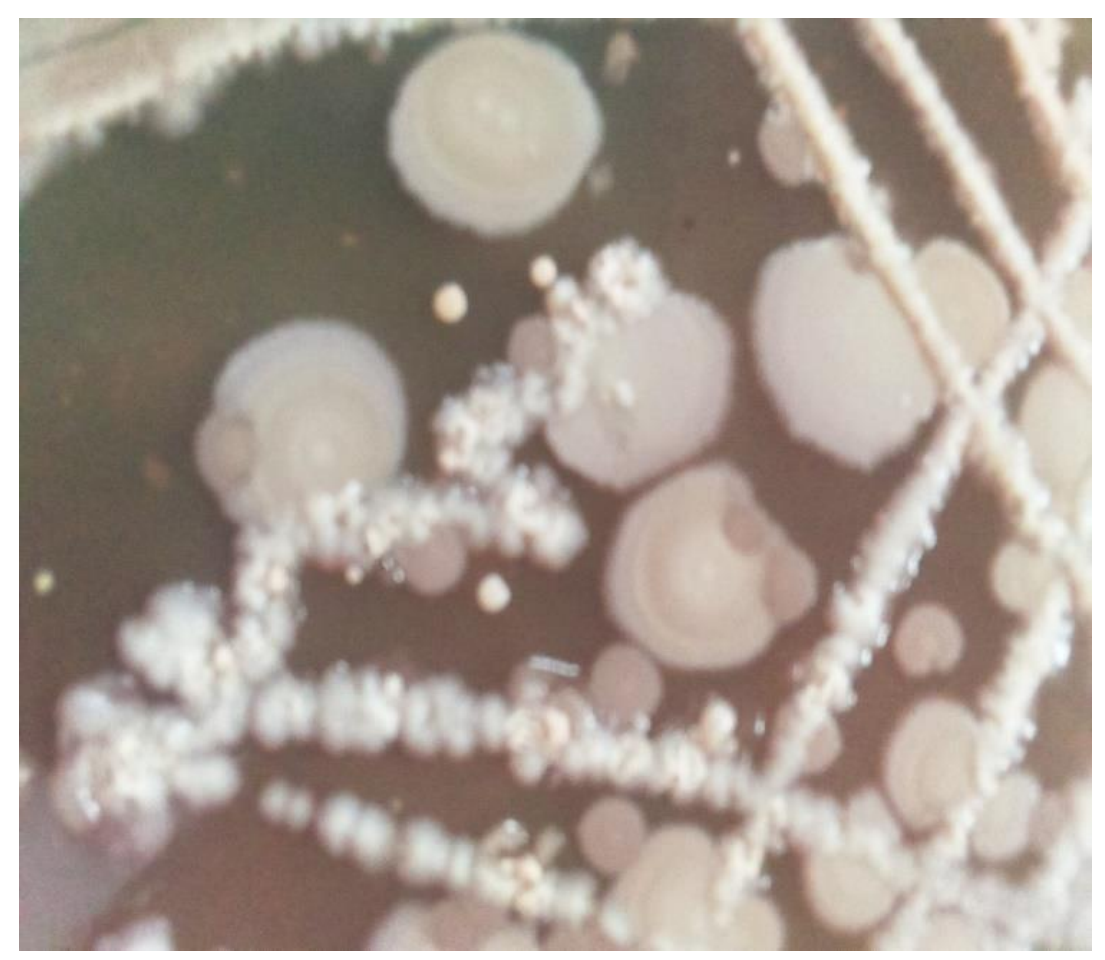

Plate5: posts mixed culture of Bacillus sp

The following organisms were isolated from milk and blood paste viz; Bacillus sp, Pseudomonas sp Enterobacter sp Klebsiella sp, Shigella sp as well as Staphylococcus. Sp. More often a suitable natural enrich medium for both nutrient broth culture as well as home base broth culture were set up for the production of both primary and secondary metabolites in-situ. Thus, Similar events were also conducted for microbial growth in solid agar medium as usual. These respective bacteria were screen and characterized owing to the nature of their survival at $\mathrm{pH} 7-8$, mode of carbon, nitrogen assimilation and morphology [83] as seen table 1, Further investigations were circumspectly accentuated regarding to phytochemical/ antioxidants microbial degraders for both primary and secondary metabolite production for pharmaceutical and industrial purposes. In view of the study on their morphological and pictorial view, they present special features regarding to their shapes, gram reaction, capsule formation and spore formation as seen in table 1: Four species (Bacillus sp, Pseudomonas sp Enterobacter sp and Klebsiella sp were found to be Rod (+) followed by Shigella sp Rod (-) and the least was Staphylococcus sp Cocci (+). Bacillus sp, are spore formers and Klebsiella sp are capsule formers while others failed to complied to their called of nature in like manner. (Enterobacter sp, Shigella sp, Staphylococcus sp). These respective results were found to have fallen in line with [83] study. Furthermore, due to their special features obtained in them; they could with stand the high test of resistant for survival at high alkaline $\mathrm{pH}$ under both aerobic and facultative condition for their survival in comparison to the others. Likewise, those of Enterobacter sp Pseudomonas sp could as well strive for carbon and nitrogen assimilation at $\mathrm{pH}$ 7-8 just to meet up their demand for survival and life continue for drugs recovery without qualm. Shigella sp, and Staphylococcus sp have little or no formation to write home about at $\mathrm{pH}$ 7-8. As seen Table 1 Plate...... and figure 1, 2, 3 and 4 


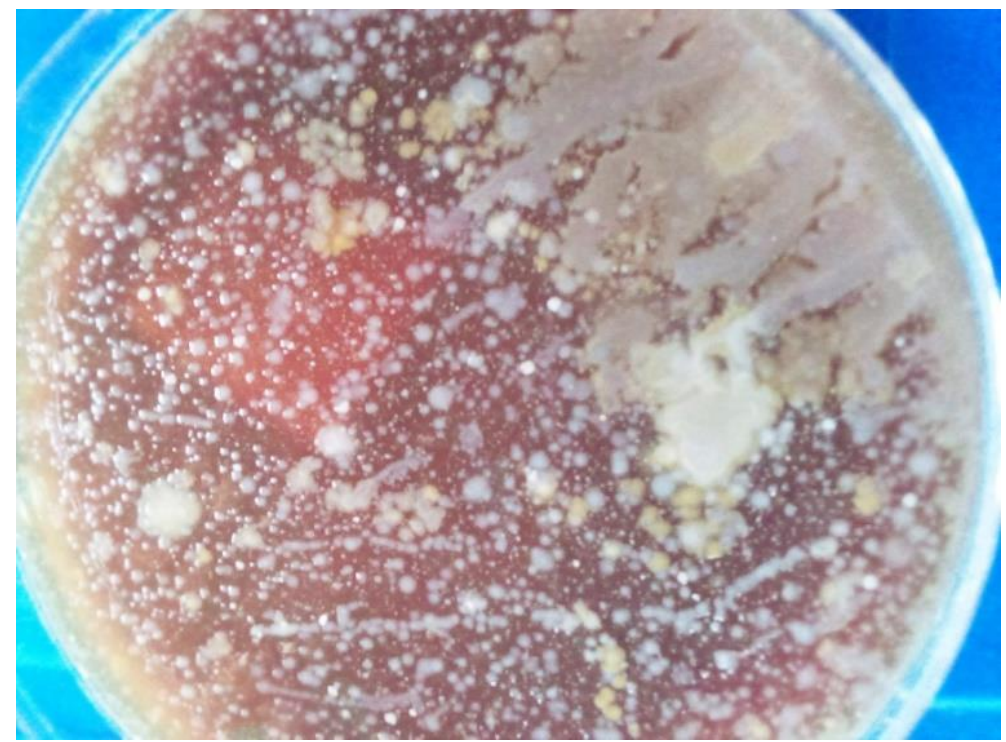

Plate 6: posts mixed culture of Bacillus sp with their motile activities

\section{MOLECULAR CHARACTERIZATIONS OF PERSISTENT BACTERIA}

Bacterial DNA quantification and purity determination In objective four, Bacillus sp, Pseudomonas sp, Klebsiella sp and Enterobacter sp were so persistent bacteria after Sodium hypochlorite disinfection. Nucleic acids have an absorption maximum at $260 \mathrm{~nm}$. Most samples contain contaminants such as proteins and single stranded DNA that absorb maximally at 280 $\mathrm{nm}$, the equation A260/A280 is used to calculate DNA in presence of contaminates. While Shigella and Staphylococcus sp were among that seem to not to be persisted during the analysis. However, Since the ratios within the acceptable limit of 1.7 and 2.0. To this effect, all the samples examined were considered pure because they were within this range as seen in (Table 2).

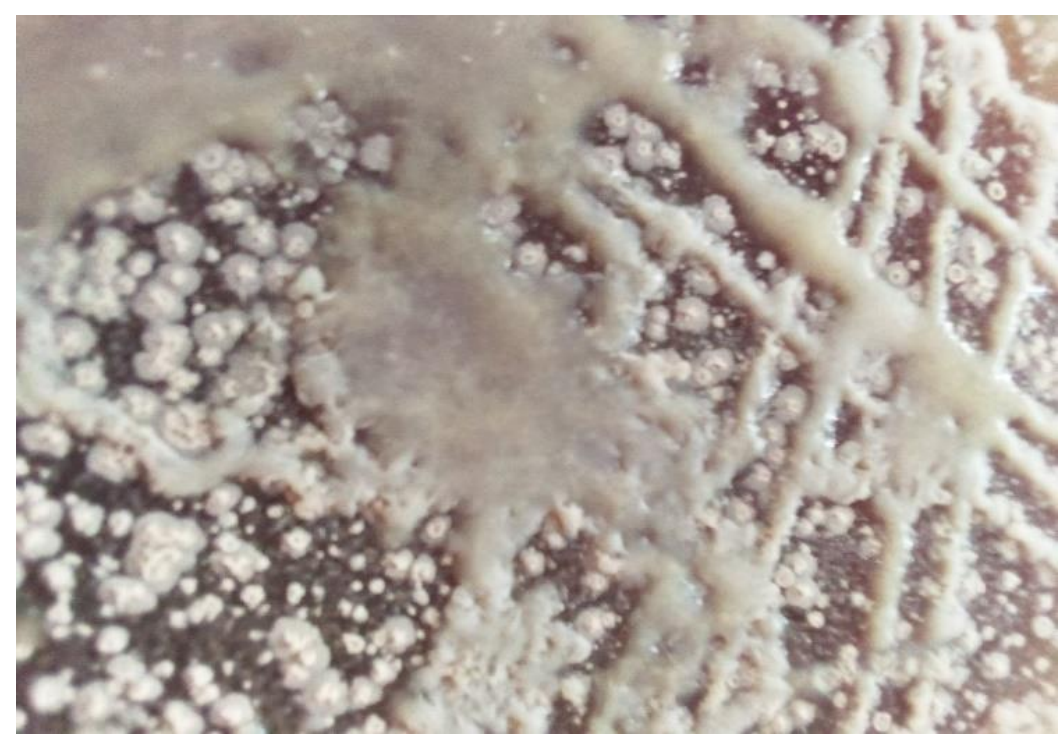

Plate 7: posts mixed culture of Klebsiella sp 


\section{GEL ELECTROPHORORESIS OF BACTERIA PERSISTEENT TO HYPOCHLORITE DISINFECTANT}

Each band represents the extracted DNA from six bacterial samples (plate1). The six samples were resistant to hypochlorite disinfection. Six bands of lane 1 Bacillus sp lane 2 Pseudomonas sp, lane 3, Enterobacter sp lane 4, shigella sp and lanes5 Klebsiella and line 6, staphylococcus sp were obtained.

Universal PCR primers selected annealed the 16S rRNA sequences. After digestion with $H A E$ III restriction enzyme, the sizes of the terminal fragments amplified with the PCR primer. The combination of PCR primer and enzyme gave the largest number of fragments with unique sizes. This analysis indicated that the universal primer pair could theoretically anneal to the largest fraction of the 16S rRNA sequences of any bacteria. However, the resulting PCR product was relatively short, and there were too few unique fragments produced upon digestion of the product with the enzymes. PCR products generated the expected fragments as shown in plate 14

\section{POLYMERASE CHAIN REACTION MASTER MIX}

Universal bacteria Primer sets 27F 5'-AGAGTTTGATCMTGGCTCAG-3' and R1525 5'AAGGAGGTGWTCCARCC -3' specific for amplifying fragment length of $996 \mathrm{bp}$, were used to amplify template DNA (Ewing and Green, 2009). The PCR program was modified slightly after initial $10 \mathrm{~min}$ denaturation at $94{ }^{\circ} \mathrm{C}$ : 30 cycles (denaturation at $94{ }^{\circ} \mathrm{C}$ for $1 \mathrm{~min}$, annealing at $54{ }^{\circ} \mathrm{C}$ for $1 \mathrm{~min}$ and extension at $72{ }^{\circ} \mathrm{C}$ for $2 \mathrm{~min}$ and final extension step at $72{ }^{\circ} \mathrm{C}$ for 10 min. The PCR products were visualized using electrophoresis in a $1 \%(\mathrm{w} / \mathrm{v})$ agarose gel electrophoresis running for $30 \mathrm{~min}$ at $80 \mathrm{~V}$ with ethidium bromide added directly to the gel at a final concentration of $0.5 \mu \mathrm{g} / \mathrm{ml}$ as seen in table 3

\section{PHYTOCHEMICAL ANTIOXIDANTS FOR HEALTH AND MEDICINE - A MOVE TOWARDS NATURE}

Phytochemicals are the chemicals extracted from plants leaves and seed like those of Bagaruwa, Tomato, neem (Azedarach), Moringa leaves, Turmeric (Curcma longa) etc., respectively. These organic plants are classified as primary or secondary constituents, depending on their role in plant metabolism. Primary constituents include the common sugars, amino acids, proteins, purines, Vitamins and pyrimidines of nucleic acids, chlorophyll's etc. Secondary constituents are the remaining plant chemicals such as alkaloids (derived from amino acids), terpenes (a group of lipids) and phenolics (derived from carbohydrates), anthraquinone flavonoids, tannins, etc., respectively as shown in table 4. These findings are in agreement with those of (Walton et al., 1999[8). However, it's possible that antioxidants which are known to be secondary constituents or metabolites found naturally in the body and in plants such as fruits and vegetables could as well play a significant role in human health system. An antioxidant can be defined in simple terms as anything that inhibits or prevents oxidation of a susceptible substrate. Plants produce a very impressive array of antioxidant compounds that includes carotenoids, flavonoids, hydroxy coumarin, quercetin, Benzophenoids, lycopene cinnamic acids, benzoic acids, folic acid, ascorbic acid, tocopherols, tocotrienols etc., respectively prevent oxidation of the susceptible substrate. Common antioxidants include vitamin $\mathrm{A}$, vitamin $\mathrm{C}$, vitamin $\mathrm{E}$, and certain compounds called carotenoids (like lutein and beta-carotene). These plant-based dietary antioxidants are believed to have an 2098 
Biotechnol. Mol. Biol. Rev. important role in the maintenance of human health because our endogenous antioxidants provide sufficient protection against the constant and unavoidable challenge of reactive oxygen species (ROS; oxidants)

Generation of free radicals or reactive oxygen species (ROS) during metabolism and other activities beyond the antioxidant capacity of a biological system gives rise to oxidative stress. Oxidative stress plays a role in heart diseases, malaria, neurodegenerative diseases, AIDS, cancer and in the aging process as seen in table 4. This concept is supported by increasing evidence that oxidative damage plays a role in the development of chronic, age-related degenerative diseases, and that dietary antioxidants oppose this and lower risk of disease and thus there arises a necessity to extract these antioxidants from the plant matrices. In a recent study different extraction technique, such as dispersed-solids, percolation, Soxhlet, microwave assisted extraction and supercritical fluid extraction have been used to isolate antioxidants from the plants. Supercritical fluid extraction (SFE) is found to be the feasible and sophisticated technology for the extraction of the antioxidants. The methodology of solid phase extraction (SPE) with super critical fluids such as $\mathrm{CO} 2$ is found to yield higher purity antioxidants. In view of the current investigation the effect of oxidants on human health and their neutralization by antioxidants. Different types of antioxidants, their properties and their extraction processes from plant matrices have been dealt in detail. Recent advances in supercritical extraction of anti-oxidants are presented.

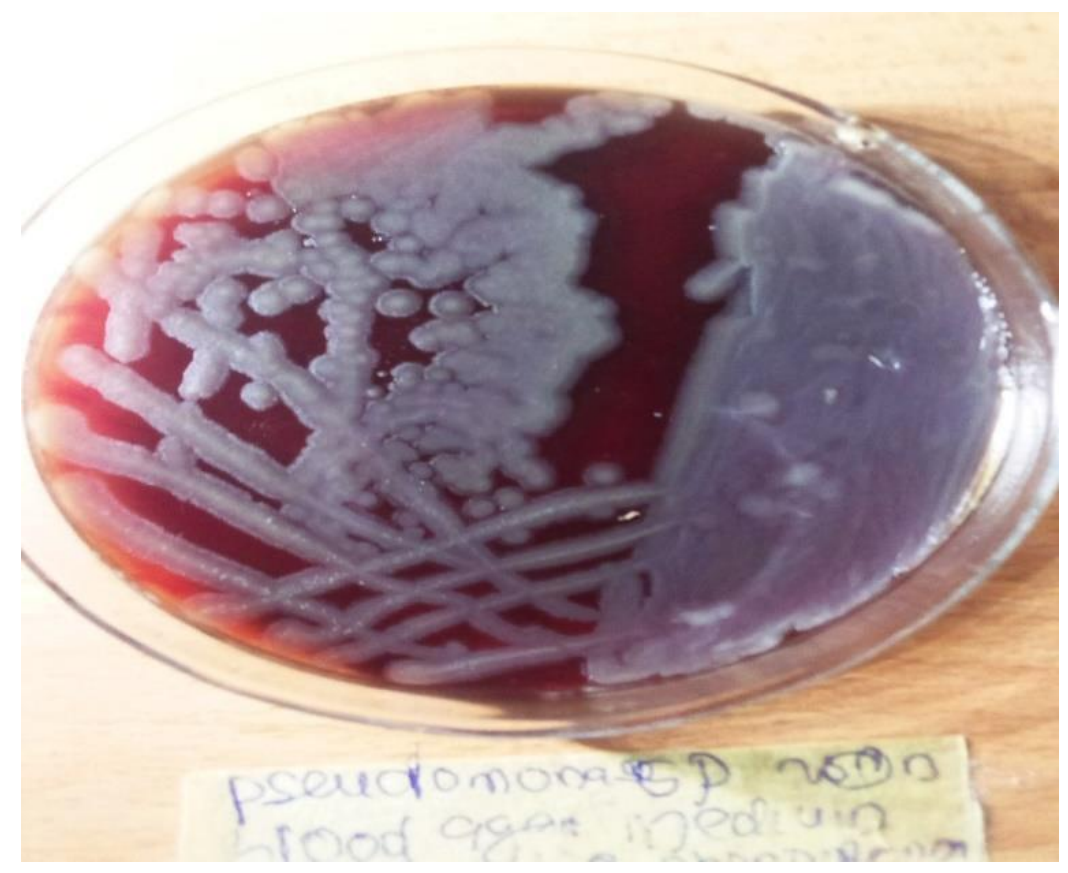

Plate 8: posted Pseudomonas sp

Antioxidants can also be manufactured synthetically. These belong to the class of synthetic antioxidants. The main disadvantage with these antioxidants is their side effect when taken in vivo [84]. Most of the natural antioxidants are found to have higher antioxidant activity when compared with that of the synthetic ones. Several arguments suggest that the antioxidant components of fruits and vegetables contribute in the defense effect. Epidemiological studies 
and intervention trials on prevention of diseases such as cancer, virus diseases (HIV/Covid 19) as well as cardiovascular disease in people have shown the negative effects of taking antioxidant supplements Carotenoids, flavonoids, cinnamic acids, benzoic acids, folic acid, ascorbic acid, tocopherols and tocotrienols are some of the antioxidants produced by the plant for their sustenance. Some of the widely known antioxidants are beta-carotene, ascorbic acid and alpha tocopherol. Beta-carotene is known as a precursor to vitamin A; it is converted to vitamin $\mathrm{A}$ in the liver and the mucous membranes of the small intestine. Beta-carotene is found to be safer as it can be ingested in almost unlimited quantities without toxic effect to the body. Ascorbic acid has multi-functional properties. Based on conditions ascorbic acid can act as an antioxidant, pro-oxidant, a metal chelator, a reducing agent or an oxygen scavenger. Ascorbic acid can act as a pro-oxidant in aqueous systems containing metals, by reducing them, which become more active catalysts of oxidation in their lower valence state. In the absence of added metals, ascorbic acid is an effective antioxidant at high concentrations [85]. Vitamin $\mathrm{E}$ is a group of compounds with well-known antioxidant functions. Among vitamin E compounds, tocopherol and especially alp tocopherol possesses the strongest biological activity. Tocopherol is prevalently found in mammalian tissue. Selenium is a naturally occurring antioxidant that preserves tissue elasticity by delaying oxidation of polyunsaturated fatty acids. $\mathrm{Se}$ is an essential component of glutathione peroxidase. Selenium deficiency has been implicated as contributing factor to the development of cardiovascular disease (congestive cardiomyopathy), accelerated atherosclerosis, skeletal muscle myopathy, increased cancer risk, aging, cataract and deranged immune function. Small molecule dietary antioxidants such as vitamin C (ascorbate), vitamin E (tocopherol), and carotenoids have generated particular interest as anticarcinogens and as defenses against degenerative diseases [86]

\section{MEDICINAL PLANTS OF AFRICAN WITH ANTIVIRAL ACTIVITIES}

Diverse plants, with their isolated products and derivatives with antiviral properties including alkaloids, flavonoids, phenolic compounds, terpenes, polysaccharides, anthraquinone, glycoside, polypeptides etc., respectively as shown in table 4 . Thus, these findings agreed with report of [87]. This could be attributed to hundreds and thousands of bioactive metabolites like those of hydroxycoumarin, quercetin, oleic acid, lactic acid, benzophenoids, lycopene beta carotenoid etc., respectively. However African medicinal plants with abundant accumulated phytochemical markers and defense compounds of chemotaxonomic have significantly played a greater role within different plant families in-situ. These variations in bioactive chemical markers in different plants has facilitated and justified the use of some plants in some families more often than others following their superior efficacy for many conditions they are meant to treat in Traditional African Medicine (TAM) including viral outbreaks. Furthermore, most bioactive compounds which are naturally designed by God, have truckload of accumulated antiviral classes of compounds that have been used scientifically viz traditional African medicine partitional; so as to ease the perpetual or lingering covid-19 pandemic affected patients within the Africa's continent area of jurisdiction as well as global. In quantum mannerism once again as seen in table 4 the bioactive/ phytochemical compounds which are invariably known to have played a significant role for antiviral properties and immunomodulatory activities could as well be served as antidot for cure or irradiation of COVID19 pandemic outbreak. in view of the current investigation, the use of traditional medicine practices has proven to be very effective, safe, affordable and accessible treatment options in comparison to the conventional/ artificial vaccine or drug. The efficacy of some plants and derived phytochemicals of African origin have been established following their potential to 
interfere with the replication and transcription machinery of some causative agents of viral infections. Documented antiviral potency of these medicinal plant extracts justifies their selection for further studies as potential agents for prophylactic administration or potential therapeutic intervention against COVID-19. However, an in-depth and rigorous analysis of their efficacy and safety using internationally acceptable protocols is germane during clinical trials prior to healthcare utilization.

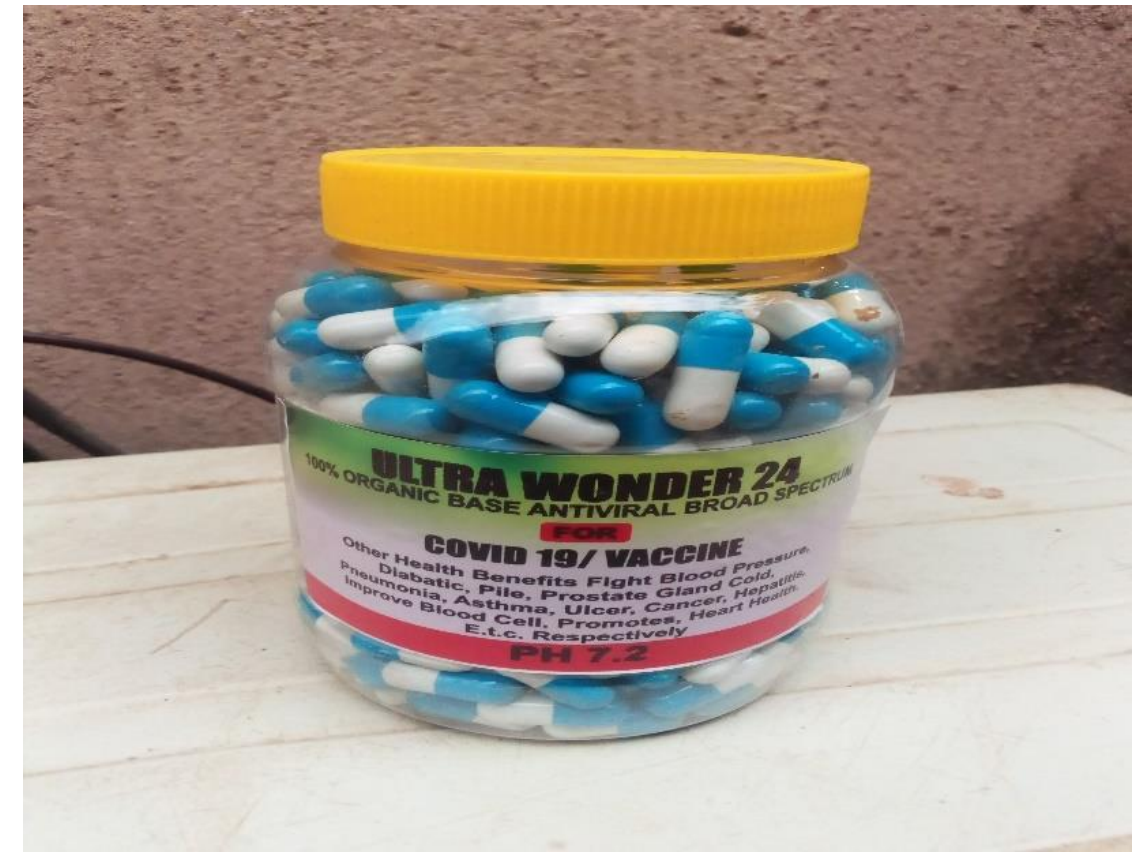

Plate 9: Posts divine fermented covid -19 vaccine/drug

\section{AFRICAN PLANT-DERIVED ANTIVIRAL METABOLITES, IMMUNOMODULATION AND MOLECULAR TARGETS}

Further investigations were made as seen in table 4 and agreed with [88] reports, of the truth Phytomedicines have shown potentials as immunoadjuvants for their ability to increase the effectiveness of vaccines while plant-derived chemical compounds including ellagic acid, curcumin, flavonoids and quercetin possess anti-infective properties that work either by directly attacking the pathogen or indirectly by stimulating innate and acquired defense mechanisms of the host. Thus, chemically diverse antiviral compounds including fermented primary enrich plants extracts (microbial metabolites/ secondary metabolites) such as polysaccharides, proteins, lectins, protein hydrolysates, aminoglycans flavonoids, lignans, coumarins, glycosides, steroids, terpenes, polypeptides, antimicrobial peptides, defensins, cyclotides etc., respectively. Many other plant-derived cystine-knot peptides have been detected and isolated from African medicinal plants. The role of these antiviral compounds and their main molecular target have been presented in Table 4 while plant families native to Africa which abundantly express and accumulate these phytocompounds that have found uses as antiinfective agents

More often Phytomedicines with a long history of use in traditional medicines and bioactive compounds obtained from them have been shown to exert antiviral, anti-inflammatory and 
immunomodulatory effects and these bioactivities have been proposed to be linked [89], following their ability to modulate the immune response and in parallel reduce viral or parasite load. These desirable dual antiviral effects have been demonstrated in indigenous plants used in TAM for the treatment of various viral diseases. For instance, "Bagaruwa" . is one of the main constituents of an indigenous Nigerian antiviral phytomedicine called "Seven Keys to Power" used in the traditional management of smallpox, chicken pox, measles and HIV/AID [90]. Turmeric (curcuma longa/ Moringa leaves, Raphanus sativus have been used by herbalists in the northern part of Nigeria for the treatment of chickenpox, smallpox, hepatitis, as well as several viral diseases. However, rigorous, robust and well validated scientific investigations are needed to turn these potential antiviral remedies to clinical use.

Bioactive protein hydrolysates and cysteine-rich polypeptides target viral membrane and proteins, alkaloids and glycosides target viral proteins and RNA, terpenes target viral membrane while steroids and flavonoids target viral RNA synthesis (as seen in table 4). For instance, the interaction between the spike glycoproteins of SARS COV-2 and the host cell angiotensin converting enzyme 2 (ACE2) receptors which leads to viral attachment and entry, culminating in COVID-19 could be prevented or blocked effectively by antiadhesive phytocompounds such as phenolics, tannins and polysaccharides, anthraquinone, steroid, glycoside etc., respectively. This report is in accordance with_[91], thus some African antiviral plants including" Bagaruwa", Tomato, Neem (Azedarachita indica), Moringa leaves(Moringa oleifera), Turmeric (Curcma longa) etc., respectively as Seen in table (4). These antiviral metabolites accumulate in high amounts in several plant families used in TAM.

\section{PHYTOCHEMICAL SCREENING OF PLANT METERIALS}

The phytochemical screening of aqueous extract (universal solvent), methanol, Ethanol and acetone extracts fromRadish (Raphanus) Neem (Azadirachta indica), Moringa leaf (Moringa oleifera), Bitter cola (Gacinia cola), Tomato (Salmum-lycoperscum), Turmeric (Curcuma longa), Bagaruwa Seed (Acacia nilotica) of all the following pharmacological importance of secondary metabolites namely Alkaloid, Saponin, Tannins, Steroids, Flavonoid, Glycoside, Terpenoid and Anthraquinones, Universal solvent $\left(\mathrm{H}_{2} \mathrm{O}\right)$ seem to have the highest dense positive, followed by Methanol/ethanol with scanty positive and the least of all was acetone with mostly negative. This study is in line with the report of [92]; hence, the curative properties of medicinal plants perhaps due the presence of above mentioning highlighted secondary metabolites. The successful extraction of various plant extract using Water, methanol, ethanol with positive results reveals the presence of Alkaloid, Saponin, Tannins, Steroids, Flavonoid, Glycoside, Terpenoid and Anthraquinones etc., respectively as shown in table: 5 . Thus, the qualitative preliminary screening test might be useful in the detection of bioactive principles and subsequently might led to drug discovery and development. Furthermore, the extract was subjected to further analytical tests for quantification of phytochemical compounds

\section{OUANTITAVE PHYTOCHEMICAL ANALYSIS}

In quantitative analysis of aqueous, methanol and ethanol extracts of from Radish (Raphanus) Neem (Azadirachta indica), Moringa leaf (Moringa oleifera), Bitter cola (Gacinia cola), Tomato (Salmum-lycoperscum), Turmeric (Curcuma longa), Bagaruwa Seed (Acacia nilotica which is mostly contained different values in their percentage exhibited for eight phytochemical tests as shown in (Table 6). Phytochemical compounds such as alkaloids, 
saponin, tannin, anthraquinones, flavonoids, glycosides, steroids, terpenes, flavonoid and were screened and quantified in their values for their bioactive principles and for drugs discovery in their extract. Although, among these compounds namely: alkaloids, saponin, tannin, anthraquinones, flavonoids, glycosides, steroids, terpenes, flavonoid are important secondary metabolites and are responsible principles for medicinal value of respective plant. In addition, the extracts were subjected to further analytical tests for quantification of phytochemical compounds. Thus the results or values obtained from various plants under alkaloid the highest value was found in tomato with $20.2 \%$, followed by moringa with $15.2 \%$ others or equivalent values Eucalyptus leaves/ Turmeric were found to be $10.20 \% / 10.30 \%$ and the least was found in "Agarwal" with $4.5 \%$. these varying degree of secondary metabolites values of different plant extracts are in agreement with the findings of Zhang and wang 2001). On the contrary Salas et al.,2002 reported less values with $9.2 \%-2.4 \%$ while wang and jiano(200) had $12 . .2 \%$ $3.4 \%$. The differences in values might be possible due to the present bioactive compound accumulated. Thus, high values content than expected in the plant could have been given birth to the hazardous nature of the plant, the microbes too during fermentation and well as human health wise as seen in table 7, plate 12 . These maximum values found in each respected plant extract has been designed by God so as to keeping the plants lively as well as the microorganisms for synergy relationship. No wonder at the onset of the reach project when the $\mathrm{pH}$ was Adjusted to 7-8 some beneficial microbes for pharmaceutical and industrial usage were always found growing in aerobic condition. But for one's information that does not grantee one safety (take note). In as much as alkaloid is considered very important in medicinal and constitute most of the values drugs discovery, it has been documented by [93] to have antioxidant activities as well as much health promoting effect such as antiviral anticancer, antiallergies anti-inflammatory.

Furthermore, the results obtained from Table 6 regarding to tannin and flavonoid plants samples show a significant difference in their respective phytochemical activities. For the tannin, moringa had the highest tannin compounds with $16.5 \%$ as well as for Flavonoid wit $15.5 \%$ found in tomato with $14.3 \%$ as well as $12.4 \%$ in moringa. Others with close values $10.5 \%$ and $9.8 \%$ tannin in both Neem and Turmeric. Similarly for close relation values in flavonoid were $10.3 \%$ and $10.2 \%$ in both Radish salvinus and Turmeric. The least values were observed in tannin with $5.6 \%$ and $6.7 \%$ from radish salvinus and Bagaruwa as well as for flavonoid were $9.2 \%$ and $5.2 \%$ from Neem and "Bagaruwa". However, the pictorial view of most values obtained from both Tannin and Flavonoid are in confirmation with the results of (Okowu, 2003). Thus, devoid of their lapses with the standard yet they still stand the chances of counteracting the oxidative damage induce by viral Covid-19 pandemic to negativism insitu. This might be one of the (mode of action) in Divine fermented covid-19 vaccine / drugs. In addition, the study suggests that both phytochemical like those of Flavonoid and Tannins possess antioxidant activities which would have mitigated truck load of viral replicates in human genomic system to nothingness. More-so Flavonoid and Tannins are phenolic compounds and plants phenolic are the major group of compounds that act as primary antioxidant of free radical scavenger.

\section{NUTRIENT SUPPLEMENT}

The most momentous weapon against any kind of viral infection is a strong immune system. There are plethora of studies done in past that suggest an imperative role of trace elements and vitamins in normal performance of the immune system. 


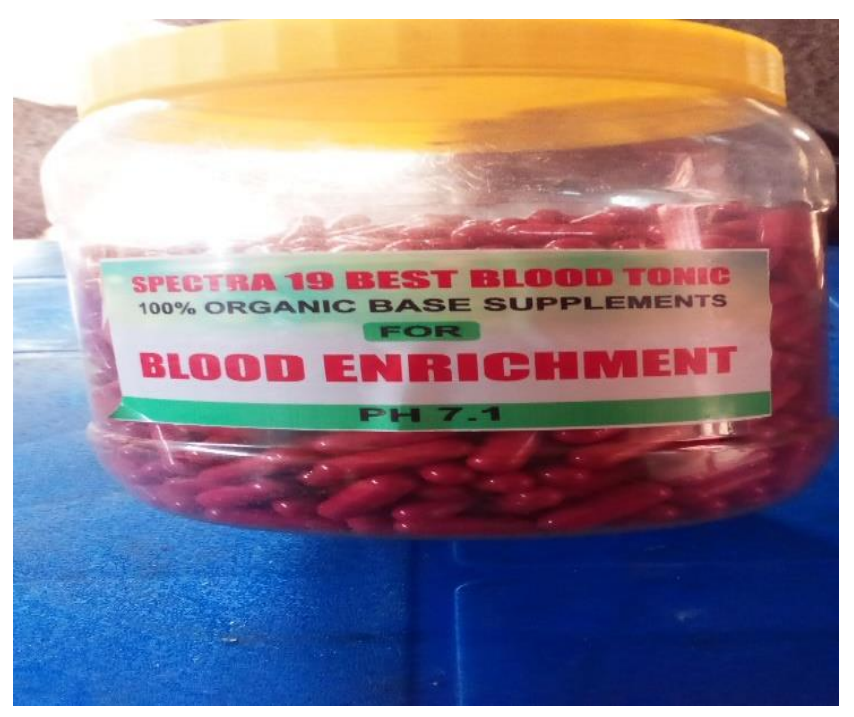

Plate 10: Posts highly enrich fermented blood tonic

Furthermore, there are reports of elevated resistant to viral infection in response to their supplementation. Vitamin D and A ingestion increased the humoral immunity in association with influenza vaccine in pediatric patients. Exogenous supplementation of Selenium has been shown to affirmatively combat influenza infection in alliance with the vaccination [94]. Apart from this, wide range of herbals, nutraceuticals and probiotics (action of fermented microbial metabolites) have been found to be effective against viral infestations and stimulation of immune responses

\section{Vitamins}

Vitamin $\mathrm{A}$ is an essential fat-soluble vitamin which has a major involvement in regulating vision, growth and maturity as well as protection of the mucosal and epithelium integrity of the human body. It has a crucial participation in elevating the immunomodulatory responses and dogmatic functions in humoral as well as cellular responses. The Vitamin A supplements given to the infants with measles and rabies showed impending improvement (2.1 times) in antibiotic response in association with the vaccinations. Vitamin D another fat-soluble vitamin and has a vital role in regulating the adaptive and innate immune responses. More recently, a study carried out by team of scientist, revealed that supplementation with high dose of vitamin $D$ (2000 IU/day) in contrast to a standard dose (400 IU/day) had no significant effect on the viral infection in the upper respiratory track, however the one third of the population was found to have vitamin D levels less than $30 \mathrm{ng} / \mathrm{ml}$. Similarly, another study suggests vitamin D supplementation with influenza vaccine resulted in enhancement in the levels of TGF- $\beta$ in the plasma which further indicated that vitamin $\mathrm{D}$ directs the lymphocytes polarization towards the tolerogenic immune response Vitamin $\mathrm{D}$ has also been affirmed to demonstrate beneficial effect against other viruses including HCV genotype infection and HCV genotype 2-3 [95]. Another report which suggests antiviral capability of Vitamin D was elucidated by [96]. It was further affirmed that Vitamin D was potent in reducing the hazards associated with viral pandemics. The high dose of Vitamin D reduced the hazard of several chronic ailments such as cardiovascular diseases, diabetes mellitus, hypertension, cancers and respiratory tract infection. Grant and co-workers, additional revealed that vitamin D lowers the risk to 
respiratory tract infection by sustaining tight junction, decline in the synthesis of proinflammatory cytokines and killing the envelope of virus via induction of defensins and cathelicidin. Consequently, the risk of cytokine storm is lowered which prevents pneumonia.

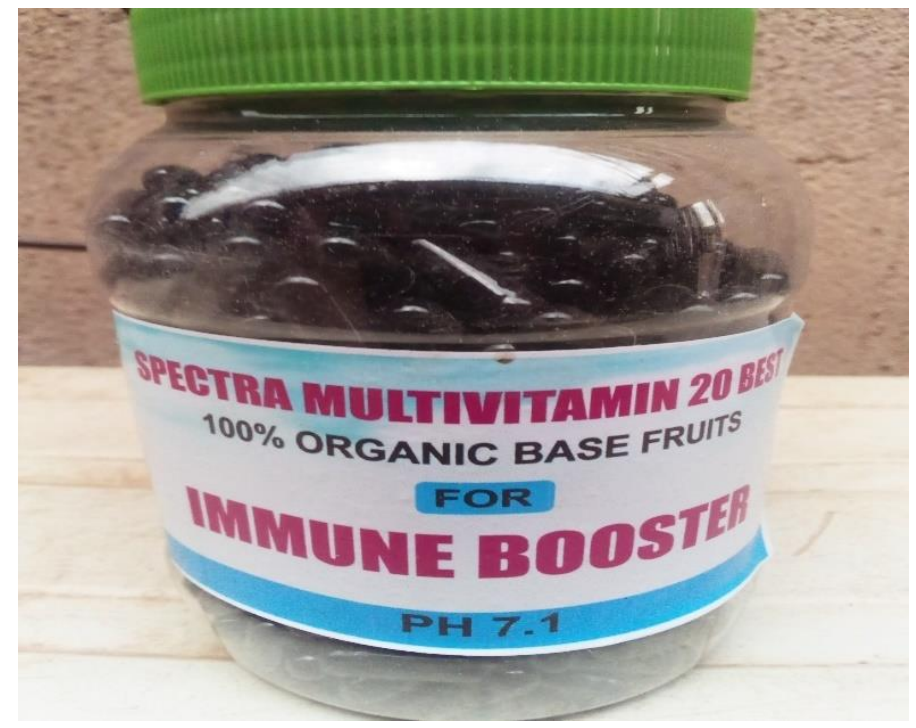

Plate 11: Posts highly enrich fermented multivitamins

Vitamin E is also a fat soluble vital and has an antioxidative potential and regulates the host's immune responses. The positive effect of vitamin $\mathrm{E}$ against chronic hepatitis. In addition, there had been an appreciable elevation in normalization of liver enzyme activity and HBVDNA negativitization. Another vitamin that acts as an important antioxidant and enzymatic cofactor is Vitamin C. It acts as a co-factor in varied physiological processes such as hormone synthesis, immune potentiation and collagen synthesis. The meta-analysis role of vitamin $\mathrm{C}$ in treatment and preventions of common cold was carried out by another team of scientist. It was concluded in the view of evidences that vitamin $\mathrm{C}$ mega dose showed reduction in the frequency of common cold in the community. A study conducted by [97] was aimed at elucidating the potential of Curcuma sp., Citrus sp., Alpinia galanga, and Caesalpinia sappan as an anti-SARS-CoV-2 agent via its binding to 3 protein receptors. The protein targets identified were Receptor Binding Domain of spike glycol proteins (RBDS), protease domain of Angiotensin Converting Enzyme-2 PD-ACE2 and SARS-CoV-2 protease by employing molecular docking technique. The result of the study revealed that Citrus sp. had the highest inhibitory potential against SARS-CoV-2, followed by galangal, sappan wood and curcuma species and it was further suggested that they might have antiviral potency against COVID-19. Additionally, different plant-based sources of vitamins include, mushrooms, carrots, broccoli, almonds, citrus, guava, amla, avocados etc., respectively. describes the role of Vitamins (A, $\mathrm{C}, \mathrm{E}$ and $\mathrm{D}$ ) in combating COVID-19 as seen in table 7 plate 10 and 11.

\section{NUTRACEUTICALS SUPPLEMENTS AND PROBIOTICS}

Nutraceuticals are the products which are argued to provide physiological assistance and protection against varied persistent diseases. Wide range of nutraceutical products have been isolated herbal products, dietary supplements, isolated nutrients, genetically engineered foods and processed cereals, beverages and soups. Certain nutraceuticals have been shown earlier to 
enhance the immune function. [98] elucidated that, a few nutraceuticals were able to lower the degree of symptoms and provide respite to the patients infected from coronavirus and influenza. Another significant product is probiotic, they are defined as live micro-organisms which bestow varied health benefits such as improvement in gastrointestinal activity. They also induce certain specific immune responses by augmenting antibody synthesis. A report by [99] suggested the role of probiotics in the improvement in immune response to vaccination in the elderly people. Antibody production against influenza B was elevated significantly against influenza and there was no effect of probiotics on IL-4 and INF secretion by cultured monocytes. Moreover, an observation made by team of scientists revealed positive effects of supplementation with Bifidobacterium longum on the immunomodulatory responses and intestinal microbiota in elderly people. A significant augmentation in the number of bifidobacteria was recorded in the faecal matter. Furthermore, it was suggested that there was an increase in serum IgA levels. An investigation was carried out to elucidate whether consumption of probiotics such as lactobacilli has an effect on acquired cold symptoms. Reduction in pharyngeal symptoms was significant was observed.

\section{POTENTIAL STRAIN CAPABLE OF SOLVENT / ANTIOXIDANT RESISTANT CAPACITY}

Six different types of bacteria strains were isolated from expose samples of milk and blood paste. After screening for potential strains capable of offering a resistant and sensitivity were used for the study four out of six potential strains were selected after secondary screening were identified base on their morphological and biochemical characteristic in Table 1 and 7. The strains were tentatively authenticated as Bacillus sp, Pseudomonas sp, Enterobacter sp, Klebsiella sp, Shigella sp and Staphylococcus sp. Taking a quantum survey of the results obtain from different bacteria namely : Bacillus sp, Enterobacter sp, Klebsiella sp, Shigella sp and Staphylococcus sp right from the top to the bottom, it appears that aqueous solvent and methanol solvent have each resistant $(\mathrm{R})$ with 10 frequent resistivity as well as methanol both of them being the highest followed by ethanol with 5 frequent Resistivity and the lest was found in acetone with 3 Frequent resistivity. Thus, others were found to be partial sensitivity (PS) as well as sensitivity(S). The study was simultaneously and vividly checkmated to be in line with report of [100]. Generally speaking, the resistivity of some certain particular strain of bacteria in water mostly have indicated that water is a universal solvent through which it exhibits some certain particular characteristics for frequent growth of Bacteria in a well enrich suitable medium or solid agar. In addition, water molecule has a polar arrangement of oxygen and hydrogen atoms one side of hydrogen has positive $(\mathrm{H}+)$ electrical charges and other of oxygen has a negative 0 - charges which allowed the water molecules to become so attracted to many other different types of molecules. When water dissociated in solution it gives $\mathrm{H}++\mathrm{OH}$ - this gives water the upper hands to react with some bacterial whose cell wall are (-) or positive $(\mathrm{H}+)$ charge. Thus that makes them (bacteria cell wall [+]or [-] charges $+\mathrm{OH}$ - or $\mathrm{H}+$ alongside with some microelement / macroelements like those of $\mathrm{Mg}+$, $\mathrm{Zn}+\mathrm{Fe}+$ so unique for certain reaction to take place in comparison to highly flammable solvent like those of Methanol, ethanol, acetone respectively with their relatives masses increase stepwise. The higher the increase of $\mathrm{CH}_{2}$ in their carbon the more sensitive the microorganisms strive to survived as seen in table 7 plates2, and 3. Furthermore, Bacillus sp and Klebsiella sp are both found to be spore former as well as capsule former that makes them to be too resistant to water molecules at $\mathrm{pH} 7-8$ while other strive to attain the degree of nature's called for survival of the fittest. Methanol, ethanol and acetone solvent tend to inhibit 
the growth of some certain bacteria to sensitivity during solvent diffusion in solid agar medium as seen table 7 plate 2 and 3. The essence of this test was to ascertain the best solvent that could use in producing an excellent result during fermentation for the production of primary and secondary metabolite products. No industry that has ever employed the use of methanol, ethanol and acetone for fermentation processes otherwise explosion will be the order of the day.

\section{PH, DRY MATTER, PROTEINS CONTENT OF MIXCULTURE OF DIFFERENT PLANT EXTRACT CONTAINING ANTIOXIDANT FOR THE PRODUCTION OF FERMENTED DRUGS AT DIFFERENT TIME INTERVAL (protease/pH7-8.}

The performance of the different plant extracts medium supplement during fermentation as an excellent source for the growth of microorganisms. In view of the significant or sufficient information in some of the primary metabolites like those of Vitamins, Proteins (Amino acid), ethanol, etc., respectively. the results in table 8 plate 12 Figure 5,6,7 and 8 has shown that there was significant decrease in $\mathrm{pH}$ as the fermentation was going on a suitable enrich medium made of different plants extracts. The proteins $\%$ of the dry matter was found to have gradually increase up to $11^{\text {th }}$ days or so, but after that there was a decrease in protein content. So, the optimum incubation period was 11 th day of fermentation as seen in table 8 fig 5 and 6 [101]. The result could be best explained by the fact that there is constant utilization of nutritional materials by the bacteria and also probably as a result of losses of organic material in gaseous form during the fermentation. $\mathrm{pH}$ values too or content during the formation period was found declining as the fermentation days increases $\mathrm{pH}, 02$ and temperature are the physical parameters that determine the growth activities of organism in a given habitat. The probably results with respect to the growth of bacteria is shown in Table 8, Plate 12 figure 8 reveal that the respective Bacteria growth strived at 7-8. According to [102] have propose that slight variation in $\mathrm{pH}$ of the medium might have an enormous effect on the growth of bacterial. Shigella sp and Staphylococcus sp were observed to be more sensitive to $\mathrm{pH}$ 7-8 while Bacillus sp, Pseudomonas sp, Enterobacter, as well as klebsiella sp were comfortably enjoyed the welcome development as a popular English man saying 'one man food is another man's poison' at $\mathrm{pH}$ 7-8. Dry weight was also found declining as the fermentation period increases, it could be probably as the bacterial enjoy the assimilation or utilization of the available carbohydrate in the medium to an extend for the production of both primary and secondary metabolites like those of proteins, vitamins, Ethanol, for industrial and pharmaceutical drug recovery then the dry weigh was as well found wanting (decreases). 


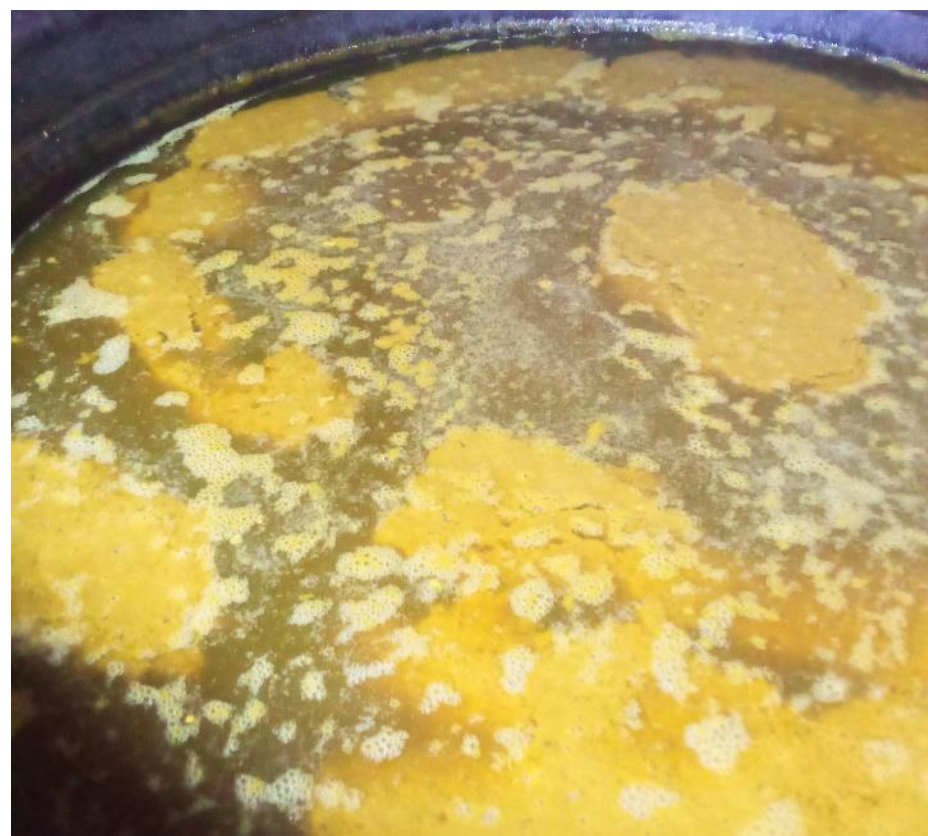

Plate 12: Posts aerobic fermentation of divine fermented Covid -19 extract from different plants

TABLE 1: IDENTIFICATION AND CHARACTERIZATION OF ISOLATES

\begin{tabular}{|c|c|c|c|c|c|c|}
\hline Characte & $\begin{array}{l}\text { Bacillus } \\
\text { sp }\end{array}$ & $\begin{array}{l}\text { Pseudomonas } \\
\text { sp }\end{array}$ & $\begin{array}{l}\text { Enterobacter } \\
\text { sp }\end{array}$ & $\begin{array}{l}\text { Shigella } \\
\text { sp }\end{array}$ & $\begin{array}{l}\text { Klebsiella } \\
\text { sp }\end{array}$ & $\begin{array}{l}\text { Staphy } \\
\text { sp }\end{array}$ \\
\hline $\begin{array}{l}\text { Umbonat } \\
\text { e Colony }\end{array}$ & - & + & - & - & - & + \\
\hline $\begin{array}{l}\text { Trimethy } \\
\text { lamimine } \\
\text { odour }\end{array}$ & - & + & - & - & - & - \\
\hline $\begin{array}{l}\text { Gram } \\
\text { reaction }\end{array}$ & + & + & + & - & + & + \\
\hline $\begin{array}{l}\text { Rods/coc } \\
\text { ci }\end{array}$ & Rods & Rods & Rods & Rods & Rods & Cocci \\
\hline $\begin{array}{l}\text { Pigment } \\
\text { productio } \\
\text { n }\end{array}$ & - & + & - & - & - & + \\
\hline Motility & + & + & + & + & - & - \\
\hline $\begin{array}{l}\text { Swarmi } \\
\text { ng }\end{array}$ & - & - & & & & - \\
\hline $\begin{array}{l}\text { Spore } \\
\text { formation }\end{array}$ & + & - & - & - & - & - \\
\hline $\begin{array}{l}\text { Capsule } \\
\text { formation }\end{array}$ & - & - & - & - & + & - \\
\hline
\end{tabular}


African Journal of Biology and Medical Research

ISSN: $2689-534 \mathrm{X}$

Volume 4, Issue 4, 2021 (pp. 53-117)

www.abjournals.org

\begin{tabular}{|c|c|c|c|c|c|c|}
\hline $\begin{array}{l}\text { Aerobic( } \\
\text { A)/ } \\
\text { Facultati } \\
\text { vely }\end{array}$ & A/F.A & A & F.A & F.A & F.A & F.A \\
\hline $\begin{array}{l}\text { Catalase } \\
\text { activity }\end{array}$ & + & + & + & + & + & + \\
\hline $\begin{array}{l}\text { Oxidase } \\
\text { activity }\end{array}$ & + & + & + & + & + & + \\
\hline $\begin{array}{l}\text { Gelatin } \\
\text { liquefacti } \\
\text { on }\end{array}$ & - & $+/-$ & - & - & - & $+/-$ \\
\hline $\begin{array}{l}\text { Lipase } \\
\text { productio } \\
\text { n }\end{array}$ & - & - & - & - & - & - \\
\hline $\begin{array}{l}\text { Arginine } \\
\text { dihydrola } \\
\text { se }\end{array}$ & ND & + & ND & ND & ND & ND \\
\hline $\begin{array}{l}\text { Indole } \\
\text { productio } \\
\text { n }\end{array}$ & + & - & - & - & + & + \\
\hline $\begin{array}{l}\text { Citrate } \\
\text { utilizatio } \\
\mathrm{n}\end{array}$ & - & - & + & $+/-$ & $+/-$ & + \\
\hline $\begin{array}{l}\text { Sodium } \\
\text { malonate } \\
\text { utilizatio } \\
n\end{array}$ & - & - & ND & ND & + & - \\
\hline $\begin{array}{l}\text { Urease } \\
\text { activity }\end{array}$ & + & + & + & + & + & - \\
\hline $\begin{array}{l}\text { Denitrific } \\
\text { ation }\end{array}$ & + & - & + & - & - & + \\
\hline $\begin{array}{l}\mathrm{H}_{2} \mathrm{~S}- \\
\text { productio } \\
\mathrm{n}\end{array}$ & - & - & - & + & + & - \\
\hline $\begin{array}{l}\text { Methyl } \\
\text { Red }\end{array}$ & + & + & + & + & $+/-$ & $+/-$ \\
\hline $\begin{array}{l}\text { Voges- } \\
\text { Proskaue } \\
\text { r }\end{array}$ & + & + & - & $+/-$ & $+/-$ & + \\
\hline $\begin{array}{l}\text { Phenylala } \\
\text { mine } \\
\text { deaminati } \\
\text { on }\end{array}$ & ND & ND & - & + & - & + \\
\hline $\begin{array}{l}\text { Lysine } \\
\text { decarbox } \\
\text { ylation }\end{array}$ & ND & - & - & - & + & + \\
\hline
\end{tabular}


African Journal of Biology and Medical Research

ISSN: 2689-534X

Volume 4, Issue 4, 2021 (pp. 53-117)

www.abjournals.org

\begin{tabular}{|c|c|c|c|c|c|c|}
\hline $\begin{array}{l}\text { Acid } \\
\text { productio } \\
\text { n from } \\
\text { glucose }\end{array}$ & + & $+/-$ & $+/-$ & + & + & + \\
\hline $\begin{array}{l}\text { Acid gas } \\
\text { productio } \\
\text { n from }\end{array}$ & + & + & + & + & - & - \\
\hline Sucrose & + & + & + & + & + & + \\
\hline Maltose & + & + & & & & \\
\hline $\begin{array}{l}\text { D- } \\
\text { Mannose }\end{array}$ & + & + & - & - & + & - \\
\hline $\begin{array}{l}\text { Hemolyti } \\
\text { c } \\
\text { Activity }\end{array}$ & Gamma & Gamma & Gamma & Gamma & Gamma & Alpha \\
\hline
\end{tabular}

Key ND: Not Done: (+)/ NEGATIVE (-)

Table :2 DNA QUANTIFICATION AND PURITY OF FREQUENT BACTERIA

\begin{tabular}{|c|c|c|c|c|c|}
\hline $\begin{array}{l}\text { Sample } \\
\text { Conc }(g / \mu l\end{array}$ & Nuclei acid & $\mathbf{A 2 6 0}$ & A280 & $260 / 280$ & Factor \\
\hline Bacillus 1 & 48.6 & 0.971 & 0.55 & 1.76 & 50 \\
\hline Bacillus2 & 1117.1 & 22.353 & 11.227 & 1.99 & 50 \\
\hline Bacillus3 & 105 & 2.099 & 1.163 & 1.81 & 50 \\
\hline Bacillus 4 & 267.6 & 5.351 & 2.78 & 1.93 & 50 \\
\hline Bacillus 4 & 153.7 & 3.075 & 1.578 & 1.95 & 50 \\
\hline Bacillus 5 & 36.5 & 0.729 & 0.374 & 1.95 & 50 \\
\hline Pseudomonas 1 & 1062.8 & 21.255 & 10.745 & 1.95 & 50 \\
\hline Pseudomonas 2 & 262.9 & 5.258 & 2.92 & 1.80 & 50 \\
\hline Pseudomonas 3 & 63.5 & 1.27 & 0.736 & 1.73 & 50 \\
\hline Pseudomonas 4 & 1672.1 & 33.443 & 17.133 & 1.95 & 50 \\
\hline Klebsiella 1 & 2113.4 & 13.21 & 6.70 & 1.98 & 50 \\
\hline Klebsiella2 & 1235.1 & 20.50 & 11.0 & 1.86 & 50 \\
\hline Klebsiella 3 & 2213.5 & 1.95 & 1.01 & 1.93 & 50 \\
\hline Klebsiela4 & 226.1 & 2.76 & 1.60 & 1.72 & 50 \\
\hline Enterobacter 1 & 223.5 & 0.737 & 0.40 & 1.84 & 50 \\
\hline Enterobacter2 & 34.0 & 4.350 & 2.50 & 1.74 & 50 \\
\hline Enterobacter3 & 143.2 & 3.271 & 1.70 & 1.92 & 50 \\
\hline Shigella & 22.5 & 12.6 & 6.51 & 1.93 & 50 \\
\hline Staphylococcus & 424.3 & 4.61 & 2.52 & 1.82 & 50 \\
\hline
\end{tabular}




\section{GEL ELECTROPHORORESIS OF BACTERIA PERSISTEENT TO} HYPOCHLORITE DISINFECTA

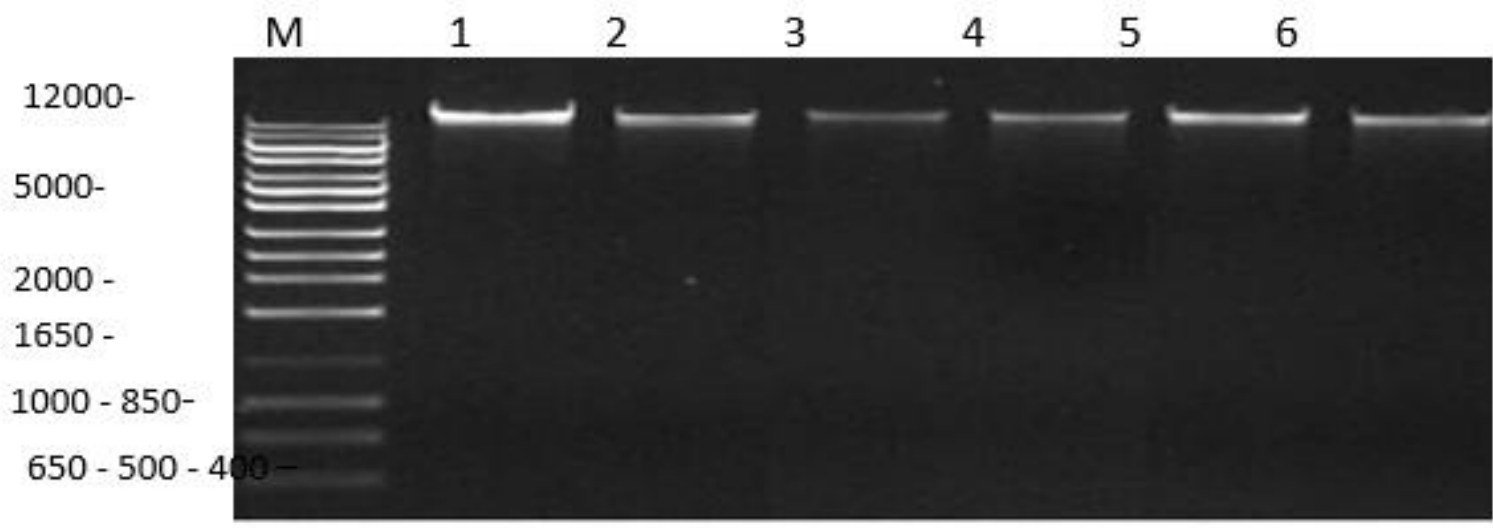

Plate 1(13): Gel electrophoresis of bacterial genomic DNA. Lanes 1, Bacillus sp; Lane 2, Pseudomonas sp; Lanes 3, Enterobacter sp; Lane 4, Shigella sp and lanes 5 Klebsiella sp and lane 6 Staphylococcus sp; M, the standard 1 kb plus marker (Promega).

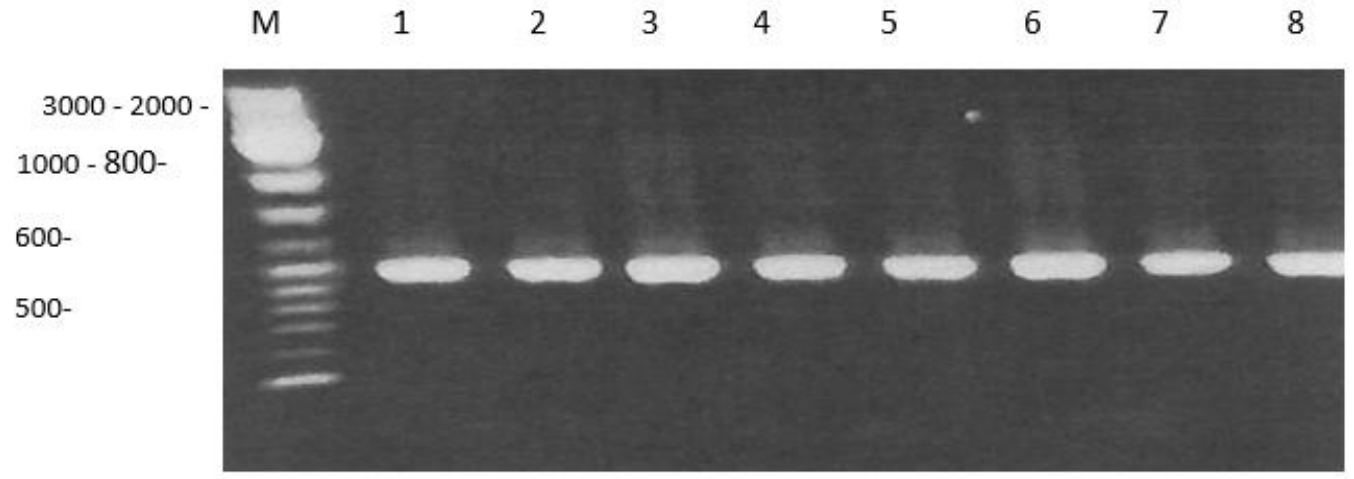

Plate (14): Gel electrophoresis in $1 \%$ agarose gel of PCR products. Lanes 1-2, Shigella sp; Lane 3- 4, B. subtilis; Lane 5-6, P. aeruginosa; Lane 7- 8, S. aureus. Lane M, 100 bp DNA marker (Sigma). 
Table 3: POLYMERASE CHAIN REACTION MASTER MIX

\begin{tabular}{lll}
\hline Component & Volume/Reaction in $\boldsymbol{\mu l}$ & Final X6 \\
\hline H20(Nuclease free) & 15.75 & $94.5 \mu 1$ \\
Buffer & 2.5 & $15 . \mu 1$ \\
$\mathrm{MgCl} 2$ & 2.5 & $15 . \mu 1$ \\
$\mathrm{dNTP3}$ & 2.5 & $15 . \mu 1$ \\
Taq polymerase & 0.25 & $15 . \mu 1$ \\
Primer F 27 & 0.63 & $3.78 \mu 1$ \\
Primer R 1525 & 0.63 & $3.78 \mu 1$ \\
\hline
\end{tabular}

\section{RESTRICTION FRAGMENT LENGTH POLYMORPHISM ANALYSIS}

The restriction patterns of the bacteria DNA were different. Isolates in lanes with the same RFLP patterns were considered to be identical (Lanes1 and 2; Lanes 3 and 4; Lanes 5 and 6; Lanes 7 and 8). Isolates in lanes with different RFLP patterns were considered unidentical therefore are the same organisms but with different chromosomes. (Lanes 1 and 3; Lane 3 and 5; Lane 5 and 7) as shown in plate 3. For bacterial identification, PCR products of each bacterium had a unique RFLP pattern and different isolated samples corresponding to one bacterial species had the same RFLP pattern (Plate 4). This shows that that they are the same

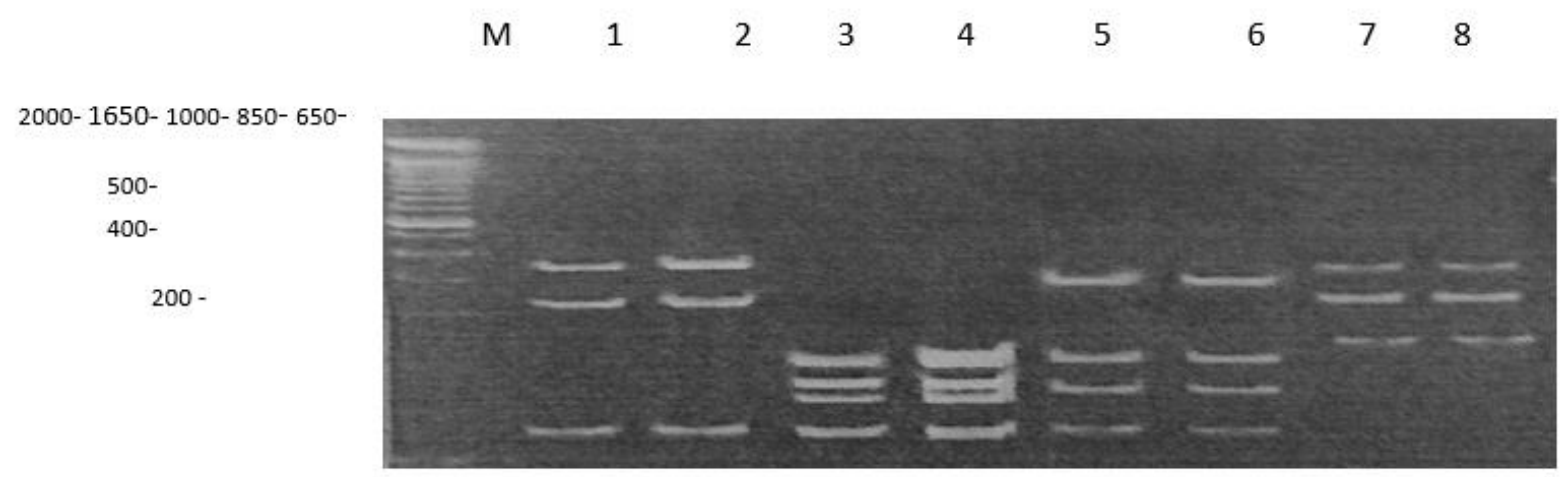

Plate15 : Hae III digestion patterns of PCR products from standard bacteria and bacterial isolates from biosafety level II laboratory. Lanes 1-2, S. aureus (Lane 1, biosafety sample and Lanes 2 standard sample NCO7447); Lanes 3-4, Shigella (Lane 3, biosafety sample and Lane 4 standard sample ATCC 25922); Lanes 5-6, P. aeruginosa (Lane 5, standard sample NC12924 and Lane 6 biosafety sample); Lanes 7-8, B. subtilis (Lane 7, standard samples NCO8241 and Lane 8, biosafety sample); Lane M 1 kb plus marker (Promega). 


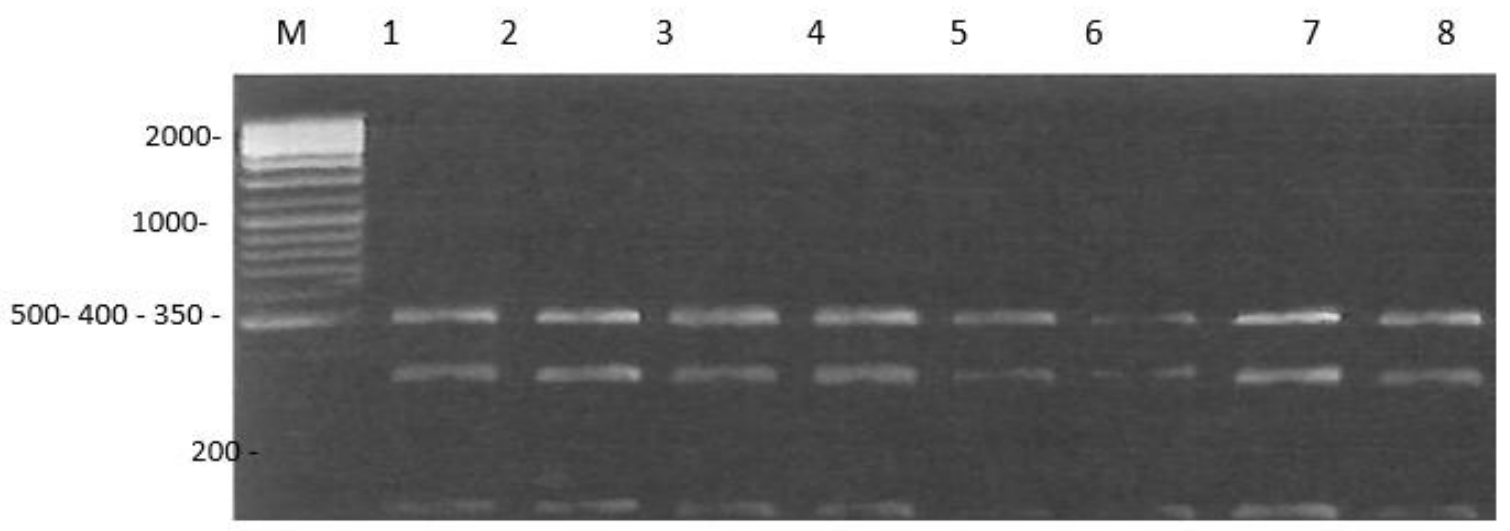

Plate (16): Assessment of 16S rRNA gene conserved fragment RFLP patterns of $P$. aeruginosa isolates: Lanes 1-8 were (Hae III) digested biosafety PCR products of different isolates that had the same RFLP patterns; Lane M 1 kb plus marker (Promega)

TABLE 4: LOCALLY AVAILABLE NIGERIA ENDIGENOUS MEDICINAL HERBS THAT HAVE BEEN REPORTED TO HAVE ANTI-COVID-19 VIRIAL INFECTION PROPERTIES

\begin{tabular}{|c|c|c|c|c|c|c|}
\hline Plant & PHYTOCHEMICAL & $\begin{array}{l}\text { NITR } \\
\text { OGEN }\end{array}$ & $\begin{array}{l}\text { BIOCHEMICAL } \\
\text { SYNTHESIS }\end{array}$ & $\begin{array}{l}\text { VITA } \\
\text { MINS }\end{array}$ & MINERALS & THERAPY \\
\hline $\begin{array}{l}\text { Raphanus } \\
\text { sativus } \\
\text { (Radish) }\end{array}$ & $\begin{array}{l}\text { Steroid, Phytosterol, } \\
\text { alkaloid, Terpenoid, } \\
\text { flavonoid, Car diac } \\
\text { glycosides, } \\
\text { Anthraquinones } \\
\text { Tannins, Saponin, } \\
\text { chalcone, Coumarin } \\
\text { Phlobatannis }\end{array}$ & $\mathrm{N}$ & $\begin{array}{l}\text { Carotenoid, } \\
\text { hydroxycoumarin, } \\
\text { Hydroxy- } \\
\text { cinnamon }\end{array}$ & $\begin{array}{l}\text { C, B, } \\
\text { K D } \\
\text { F }\end{array}$ & $\begin{array}{l}\mathrm{P}, \mathrm{Zn}, \mathrm{Mn}, \\
\mathrm{Cu}, \mathrm{Fe}\end{array}$ & $\begin{array}{l}\text { Antiviral, } \\
\text { properties }\end{array}$ \\
\hline $\begin{array}{l}\text { NEEM } \\
\text { (Azedarach) }\end{array}$ & $\begin{array}{l}\text { Alkaloid, Terpenoid, } \\
\text { flavonoid } \\
\text { Anthraquinones, } \\
\text { car diac glycosides, } \\
\text { Tannins, }\end{array}$ & $\mathrm{N}$ & $\begin{array}{l}\text { Azadirachtin, } \\
\text { Azadinone, } \\
\text { Salanin } \\
\text { Carotenoid, } \\
\text { Azadirachtin, } \\
\text { quercetin, Oleic } \\
\text { acid }\end{array}$ & $\begin{array}{l}\text { B2, } \\
\text { B6, C }\end{array}$ & $\begin{array}{l}\mathrm{Cu}, \mathrm{fe}, \mathrm{Mn}, \\
\mathrm{Mg}, \mathrm{K}\end{array}$ & $\begin{array}{l}\text { Antiviral } \\
\text { properties }\end{array}$ \\
\hline $\begin{array}{l}\text { Moringa Leaf } \\
\text { (Moringa } \\
\text { oleifera) }\end{array}$ & $\begin{array}{l}\text { Alkaloid, Terpenoid, } \\
\text { flavonoid } \\
\text { Car diac glycosides, } \\
\text { Tannins, }\end{array}$ & $\mathrm{N}$ & $\begin{array}{l}\text { Carotenoid, } \\
\text { quercetin, Oleic } \\
\text { acid }\end{array}$ & $\begin{array}{l}\text { A, E, } \\
\text { F, C }\end{array}$ & $\begin{array}{l}\mathrm{Ca}, \mathrm{Fe}, \mathrm{Mn}, \\
\mathrm{Mg}, \mathrm{Na}\end{array}$ & $\begin{array}{l}\text { Antiviral } \\
\text { Properties }\end{array}$ \\
\hline $\begin{array}{l}\text { Eucalyptus } \\
\text { Leaf } \\
\text { (Eucalyptus), }\end{array}$ & $\begin{array}{l}\text { Steroid, Phytosterol, } \\
\text { alkaloid, terpenoid, } \\
\text { flavonoid, car disc } \\
\text { glycosides, } \\
\text { Anthraquinones } \\
\text { Tannins, Saponin, } \\
\text { Phytosterols, TECO } \\
\text { sterol }\end{array}$ & $\mathrm{N}$ & $\begin{array}{l}\text { Beta-carotene } \\
\text { Lycopene } \\
\text { Alpha- tocopherol } \\
\text { Ascorbic acid } \\
\text { Glutathione }\end{array}$ & $\begin{array}{l}\text { A, C, } \\
\text { B, E } \\
\text { D }\end{array}$ & $\begin{array}{l}\text { Manganese } \\
\text { Iron (Fe), } \\
\text { Cupper }(\mathrm{Cu}) \\
\text { Potassium } \\
(\mathrm{K}), \\
\mathrm{Mg}, \mathrm{Zn}\end{array}$ & $\begin{array}{l}\text { Antiviral } \\
\text { properties }\end{array}$ \\
\hline
\end{tabular}


African Journal of Biology and Medical Research

ISSN: $2689-534 \mathrm{X}$

Volume 4, Issue 4, 2021 (pp. 53-117)

www.abjournals.org

\begin{tabular}{|c|c|c|c|c|c|c|}
\hline $\begin{array}{l}\text { Bitter Cola } \\
\text { (Garcinia } \\
\text { Kola) }\end{array}$ & $\begin{array}{l}\text { Alkaloid, } \\
\text { Saponin, tannins, } \\
\text { steroid, flavonoid, } \\
\text { Terpenoid } \\
\text { Glycoside } \\
\text { Anthraquinone }\end{array}$ & $\mathrm{N}$ & $\begin{array}{l}\text { Benzophenone, } \\
\text { kola none, Kola } \\
\text { flavanone } \\
\text { Benzophenone }\end{array}$ & $\begin{array}{l}\text { A, C, } \\
\text { E, B1, } \\
\text { B2, } \\
\text { B3 }\end{array}$ & $\begin{array}{l}\text { Fe, K Zn P } \\
\text { mg Mn, C a, } \\
\text { Cu }\end{array}$ & $\begin{array}{l}\text { Antiviral } \\
\text { properties }\end{array}$ \\
\hline $\begin{array}{l}\text { Tomato (Sal } \\
\text { mum } \\
\text { Lycopersicon) }\end{array}$ & $\begin{array}{l}\text { Alkaloid, } \\
\text { Saponin, flavonoid, } \\
\text { Glycoside }\end{array}$ & $\mathrm{N}$ & $\begin{array}{l}\text { Carotenoid's } \\
\text { Hydrocarbon } \\
\text { Caffeine }\end{array}$ & $\begin{array}{l}\mathrm{A}, \mathrm{C}, \\
\mathrm{K}\end{array}$ & $\begin{array}{l}\text { Potassium } \\
\text { Fe, } \\
\text { Manganese } \\
\text { P Zn }\end{array}$ & $\begin{array}{l}\text { Antiviral } \\
\text { properties }\end{array}$ \\
\hline $\begin{array}{l}\text { Turmeric } \\
\text { (Curcuma } \\
\text { longa) }\end{array}$ & $\begin{array}{l}\text { Alkaloid, } \\
\text { Saponin, tannins, } \\
\text { Steroid, Flavonoid, } \\
\text { Glycoside }\end{array}$ & $\mathrm{N}$ & $\begin{array}{l}\text { Curcuminoid, } \\
\text { Beta-carotene }\end{array}$ & $\begin{array}{l}\text { A C B } \\
\text { E }\end{array}$ & $\begin{array}{l}\text { Calcium }(\mathrm{Ca}), \\
\text { Iron }(\mathrm{Fe}), \\
\text { Potassium }(\mathrm{K}) \\
\text { Phosphorus }(\mathrm{p})\end{array}$ & $\begin{array}{l}\text { Antiviral } \\
\text { properties }\end{array}$ \\
\hline $\begin{array}{l}\text { Bagaruwa } \\
\text { (Acacia } \\
\text { Nilotic a) }\end{array}$ & $\begin{array}{l}\text { Alkaloid, } \\
\text { Saponin, Tannins, } \\
\text { Steroid, flavonoid, } \\
\text { Terpenoid } \\
\text { Glycoside } \\
\text { anthraquinone }\end{array}$ & $\mathrm{N}$ & $\begin{array}{l}\text { Alpha- } \\
\text { galactosides } \\
\text { Lactic acid } \\
\text { d-lactic acid }\end{array}$ & $\begin{array}{l}\text { A, E, } \\
D, C\end{array}$ & $\begin{array}{l}\text { Calcium }(\mathrm{Ca}), \\
\text { Iron }(\mathrm{Fe}), \\
\text { Potassium }(\mathrm{K}) \\
\text { Phosphorus }(\mathrm{p}) \\
\mathrm{Zn}, \mathrm{Mn}, \mathrm{Cu}, \\
\mathrm{Na}\end{array}$ & $\begin{array}{l}\text { Antiviral } \\
\text { properties }\end{array}$ \\
\hline
\end{tabular}

Table 5: QUALITATIVE ESTIMATION OF PHARMACOLOGICALLY IMPORTANTS SECONDRY MATABOLITES CONSTITUENT OF PLANT SPECIES USING AQUEOUS EXTRACTS, ETHANOL METHANOL AND ACETONE

\begin{tabular}{|c|c|c|c|c|c|c|c|c|c|}
\hline $\begin{array}{l}\text { Name of the } \\
\text { plants }\end{array}$ & Extraction & Alkaloid & $\begin{array}{l}\text { Saponin } \\
\text { S }\end{array}$ & $\begin{array}{l}\text { Tannin } \\
\mathrm{S}\end{array}$ & $\begin{array}{l}\text { Steroid } \\
\mathrm{S}\end{array}$ & $\begin{array}{l}\text { Fla } \\
\text { von } \\
\text { oid } \\
\end{array}$ & $\begin{array}{l}\text { Gly } \\
\text { cosi } \\
\text { de } \\
\end{array}$ & $\begin{array}{l}\text { Ter } \\
\text { pen } \\
\text { oid } \\
\end{array}$ & $\begin{array}{l}\text { Anthraq } \\
\text { uinone }\end{array}$ \\
\hline Radish & Water & +++ & - & + & + & ++ & + & - & ++ \\
\hline \multirow[t]{3}{*}{ (Raphanus) } & Methanol & + & + & + & + & + & + & + & + \\
\hline & Ethanol & + & + & _ & - & _ & - & + & - \\
\hline & Acetone & + & ++ & - & - & - & - & - & + \\
\hline Neem & Water & ++ & ++ & + & + & ++ & ++ & ++ & + \\
\hline \multirow[t]{3}{*}{ (Azadirachta) } & Methanol & + & + & + & + & + & + & - & + \\
\hline & Ethanol & + & + & + & + & _ & + & + & _ \\
\hline & Acetone & - & + & - & + & - & - & - & - \\
\hline Moringa & Water & ++ & + & + & + & ++ & ++ & + & - \\
\hline leaf(Moringa o & Methanol & + & + & + & + & - & + & ++ & - \\
\hline \multirow[t]{2}{*}{ leifera } & Ethanol & + & _ & - & + & _ & + & + & - \\
\hline & Acetone & + & - & + & - & + & _ & - & - \\
\hline \multirow{4}{*}{$\begin{array}{l}\text { Eucalyptus } \\
\text { leaf(Eucalyptus } \\
\text { gunnii) }\end{array}$} & Water & ++ & + & + & + & ++ & ++ & ++ & +++ \\
\hline & Methanol & + & _ & + & _ & + & + & + & ++ \\
\hline & Ethanol & + & + & _ & + & + & + & - & + \\
\hline & Acetone & - & + & + & - & - & - & + & - \\
\hline \multirow{4}{*}{$\begin{array}{l}\text { Bitter cola } \\
\text { (Gacinia cola) }\end{array}$} & Water & +++ & ++ & ++ & ++ & ++ & + & +++ & ++ \\
\hline & Methanol & _ & + & + & + & + & + & & + \\
\hline & Ethanol & + & - & + & - & - & - & & - \\
\hline & Acetone & - & - & _ & + & - & + & & _ \\
\hline \multirow{4}{*}{$\begin{array}{l}\text { Tomato } \\
\text { (Salmum } \\
\text { Lycoperscum) }\end{array}$} & Water & ++ & - & - & + & +++ & + & ++ & - \\
\hline & Methanol & + & - & - & _ & + & + & + & - \\
\hline & Ethanol & _ & - & - & - & + & - & + & - \\
\hline & Acetone & - & - & - & - & - & - & - & _ \\
\hline
\end{tabular}


African Journal of Biology and Medical Research

ISSN: $2689-534 \mathrm{X}$

Volume 4, Issue 4, 2021 (pp. 53-117)

www.abjournals.org

\begin{tabular}{llllllllll} 
Turmaric & Water & +++ & + & + & ++ & ++ & + & ++ & +++ \\
(curcuma & Methanol & ++ & + & + & - & + & + & + & ++ \\
longa & Ethanol & + & - & - & - & - & - & - & - \\
& Acetone & - & - & - & - & - & - & & - \\
Bagaruwa & Water & ++ & + & +++ & + & ++ & + & ++ & +++ \\
Seed(Acacia & Methanol & + & - & ++ & - & + & + & + & ++ \\
nilotica) & Ethanol & - & - & + & - & - & - & - & + \\
& Acetone & - & - & - & - & - & - & - & - \\
\hline
\end{tabular}

KEY: ++++ Abundant: Moderate +++: Scanty ++

Table 6: QUANTITATIVE ESTIMATION OF PHARMACOLOGICALLY IMPORTANTS SECONDRY MATABOLITES IN THE TAXA STUDIED OF PLANT EXTRACTS

\begin{tabular}{lllllllll}
\hline Taxa & $\begin{array}{l}\text { Alka } \\
\text { loids } \\
(\%)\end{array}$ & $\begin{array}{l}\text { Saponins } \\
(\%)\end{array}$ & $\begin{array}{l}\text { Tannins } \\
(\%)\end{array}$ & $\begin{array}{l}\text { Steroids } \\
(\%)\end{array}$ & $\begin{array}{l}\text { Flavo } \\
\text { noids } \\
(\%)\end{array}$ & $\begin{array}{l}\text { Glycosides } \\
(\%)\end{array}$ & $\begin{array}{l}\text { Terpenoids } \\
(\%)\end{array}$ & $\begin{array}{l}\text { Anthra } \\
\text { quinones } \\
(\%)\end{array}$ \\
\hline Radis( Raphanus & 10.20 & 10.3 & 5.6 & 3.9 & 10.3 & 10.2 & 8.9 & 12.3 \\
$\begin{array}{l}\text { Neem leaf } \\
\text { (Azadirachta }\end{array}$ & 9.8 & 10.10 & 9.8 & 2.7 & 9.2 & 5.6 & 7.4 & 11.4 \\
$\begin{array}{l}\text { indica } \\
\begin{array}{l}\text { Moringa leaf } \\
\text { (Moringa oleifera) }\end{array}\end{array}$ & 15.2 & 14.5 & 16.5 & 1.2 & 12.4 & 6.3 & 7.5 & 7.8 \\
$\begin{array}{l}\text { Eucalytus leaf ( } \\
\text { Eucalytus gunnii) }\end{array}$ & 10.20 & 9.3 & 8.3 & 3.2 & 10.4 & 13.2 & 6.4 & 15.6 \\
$\begin{array}{l}\text { Tomato (Salmum } \\
\text { lycoperscum }\end{array}$ & 20.02 & 15.4 & 14.3 & 0.5 & 15.5 & 6.3 & 7.5 & 0.3 \\
$\begin{array}{l}\text { Turmeric } \\
\text { (curcumalonga }\end{array}$ & 10.3 & 8.9 & 10.5 & 6.7 & 10.2 & 9.2 & 7.8 & 13.5 \\
$\begin{array}{l}\text { Bagaruwa(Acacia } \\
\text { nilotica }\end{array}$ & 4.5 & 3.5 & 6.7 & 8.2 & 5.2 & 5.6 & 6.7 & 15.3 \\
\hline \begin{tabular}{l} 
KEY: Maximat \\
\hline
\end{tabular} & & & & & & & & \\
\hline
\end{tabular}

KEY: Maximum Requirements by Bacteria for their survival and antioxidants utilization for the destruction of virus more microbial proteins, microbial vitamins, microbial mineral, as well as less toxic effect to humans 
Table 7: POTENTIAL STRAIN CAPABLE OF SOLVENT / ANTIOXIDANT RESISTANT CAPACITY

\begin{tabular}{|c|c|c|c|c|}
\hline \multirow[b]{2}{*}{ Strain } & \multicolumn{4}{|c|}{ Solvent/ Antioxidant Resistant Strain } \\
\hline & $\begin{array}{l}\text { Universal } \\
\text { solvent } \\
\text { Aqueous }\left(\mathbf{H}_{2} \mathbf{0}\right)\end{array}$ & $\begin{array}{l}\text { Methanol } \\
(97-100 \%)\end{array}$ & $\begin{array}{l}\text { Ethanol } \\
(97-100 \%)\end{array}$ & $\begin{array}{l}\text { Acetone } \\
(97-100 \%)\end{array}$ \\
\hline Bacillus1 & $\mathbf{R}$ & $\overline{\mathbf{R}}$ & $\mathbf{S}$ & $\mathbf{S}$ \\
\hline Bacillus2 & $\mathbf{R}$ & $\mathbf{R}$ & $\mathbf{S}$ & $\mathbf{S}$ \\
\hline Bacillus3 & PS & $\mathbf{R}$ & $\mathbf{R}$ & $\mathbf{S}$ \\
\hline Bacillus4 & $\mathbf{S}$ & $\mathbf{S}$ & $\mathbf{R}$ & $\mathbf{R}$ \\
\hline Bacillus4 & $\mathbf{R}$ & $\mathbf{R}$ & $\mathbf{R}$ & $\mathbf{S}$ \\
\hline Bacillus5 & PS & $\mathbf{R}$ & PS & $\mathbf{R}$ \\
\hline Pseudomanas1 & $\mathbf{R}$ & PS & $\mathbf{S}$ & $\mathbf{S}$ \\
\hline Pseudomanas2 & $\mathbf{R}$ & $\mathbf{R}$ & PS & PS \\
\hline Pseudomanas3 & $\mathbf{R}$ & $\mathbf{R}$ & PS & PS \\
\hline Klebsiella 1 & $\mathbf{R}$ & PS & $\mathbf{S}$ & PS \\
\hline Klebsiella 2 & PS & $\mathbf{R}$ & $\mathbf{R}$ & PS \\
\hline Klebsiella 3 & PS & $\mathbf{R}$ & $\mathbf{S}$ & PS \\
\hline Enterobacter1 & $\mathbf{R}$ & PS & $\mathbf{S}$ & $\mathbf{S}$ \\
\hline Enterobacter2 & PS & $\mathbf{R}$ & PS & $\mathbf{R}$ \\
\hline Enterobacter3 & $\mathbf{R}$ & $\mathbf{S}$ & $\mathbf{R}$ & PS \\
\hline Shigella & $\mathbf{R}$ & $\mathbf{S}$ & PS & PS \\
\hline Staphylococcus & PS & PS & PS & PS \\
\hline
\end{tabular}

Key: R= Resistant, $S=$ Sensitive, $\mathbf{P S}=$ Partial Sensitive

Table 8 : PH, DRY MATTER, PROTEINS CONTENT OF MIXCULTURE OF DIFFERENT PLANT EXTRACT CONTAINING ANTIOXIDANT FOR THE PRODUCTION OF FERMENTED DRUGS AT DIFFERENT TIME INTERVAL (protease/pH7-7.4) Table

\begin{tabular}{|c|c|c|c|c|c|c|c|c|c|c|c|c|}
\hline \multirow{2}{*}{$\begin{array}{l}\text { Bacteria } \\
\text { strain used }\end{array}$} & \multicolumn{3}{|c|}{ Oday } & \multicolumn{3}{|c|}{$5^{\text {th }}$ Days } & \multicolumn{3}{|c|}{$7^{\text {th }}$ Days } & \multicolumn{3}{|c|}{$12^{\text {th }}$ Days } \\
\hline & pH & $\begin{array}{l}\mathrm{DM}(\mathrm{gm} / \\
100 \mathrm{ml})\end{array}$ & $\begin{array}{l}\text { Prot } \\
\text { ein\% }\end{array}$ & pH & $\begin{array}{l}\mathrm{DM}(\mathrm{gm} / \\
100 \mathrm{ml})\end{array}$ & $\begin{array}{l}\text { Prot } \\
\text { ein\% }\end{array}$ & $\mathbf{p H}$ & $\begin{array}{l}\mathrm{DM}(\mathrm{gm} / \\
100 \mathrm{ml})\end{array}$ & $\begin{array}{l}\text { Prot } \\
\text { ein\% }\end{array}$ & pH & $\begin{array}{l}\mathrm{DM}(\mathrm{gm} / \\
100 \mathrm{ml})\end{array}$ & $\begin{array}{l}\text { Prot } \\
\text { ein\% }\end{array}$ \\
\hline Bacillus Sp & 7.4 & 4.12 & 4.5 & 7.1 & 3.45 & 9.7 & 6.68 & 3.02 & 11.20 & 6.52 & 2.87 & 10.00 \\
\hline $\begin{array}{l}\text { Pseudomonas } \\
\text { sp }\end{array}$ & 7.4 & 4.38 & 4.4 & 7.0 & 3.55 & 8.8 & 6.67 & 3.0 & 10.23 & 6.50 & 2.88 & 9.89 \\
\hline Klebsiella sp & 7.4 & 4.30 & 4.2 & 7.0 & 3.66 & 8.78 & 6.68 & 3.30 & 10.10 & 6.51 & 3.02 & 10.00 \\
\hline Shigella sp & 7.4 & 4.38 & 3.6 & 7.3 & 4.22 & 4.2 & 6.78 & 4.0 & 5.7 & 6.71 & 3.38 & 5.4 \\
\hline Staphaloccus sp & 7.4 & 4.36 & 3.5 & 7.3 & 4.0 & 3.96 & 6.88 & 3.89 & 5.34 & .6 .78 & 3.22 & 5.00 \\
\hline
\end{tabular}

Key: DM =Dry matter 
African Journal of Biology and Medical Research

ISSN: $2689-534 \mathrm{X}$

Volume 4, Issue 4, 2021 (pp. 53-117)

www.abjournals.org

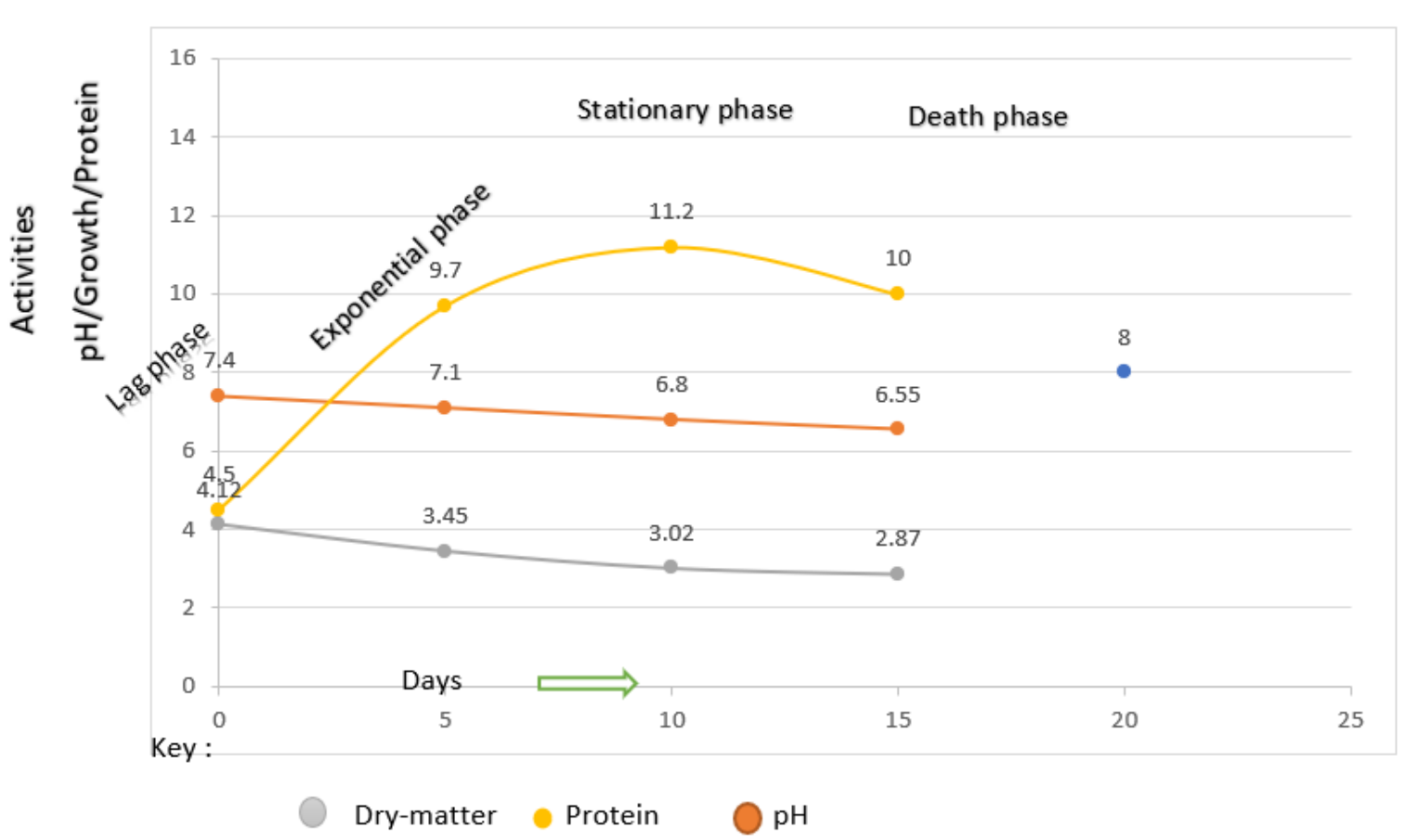

Figure: 5: pH, Dry-matter and Protein of fermented different plan extra containing antioxidant at different time interval of fermentation using Bacillus spices

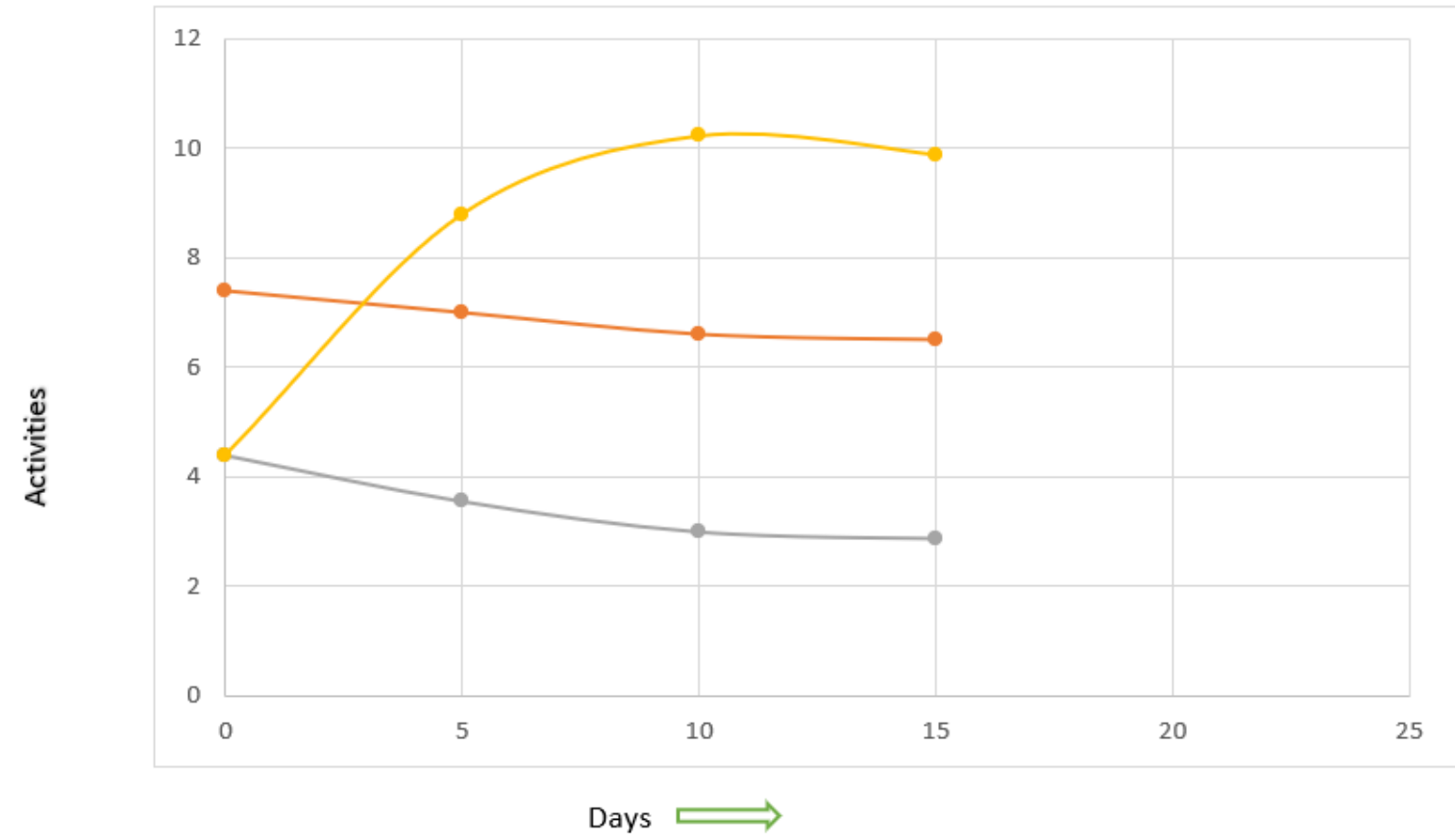

Key :
Dry-matter Protein
$\mathrm{pH}$

Figure: 6 : pH, Dry-matter and Protein of fermented different plan extra containing antioxidant at different interval of fermentation using pseudomonas spices 
African Journal of Biology and Medical Research

ISSN: $2689-534 \mathrm{X}$

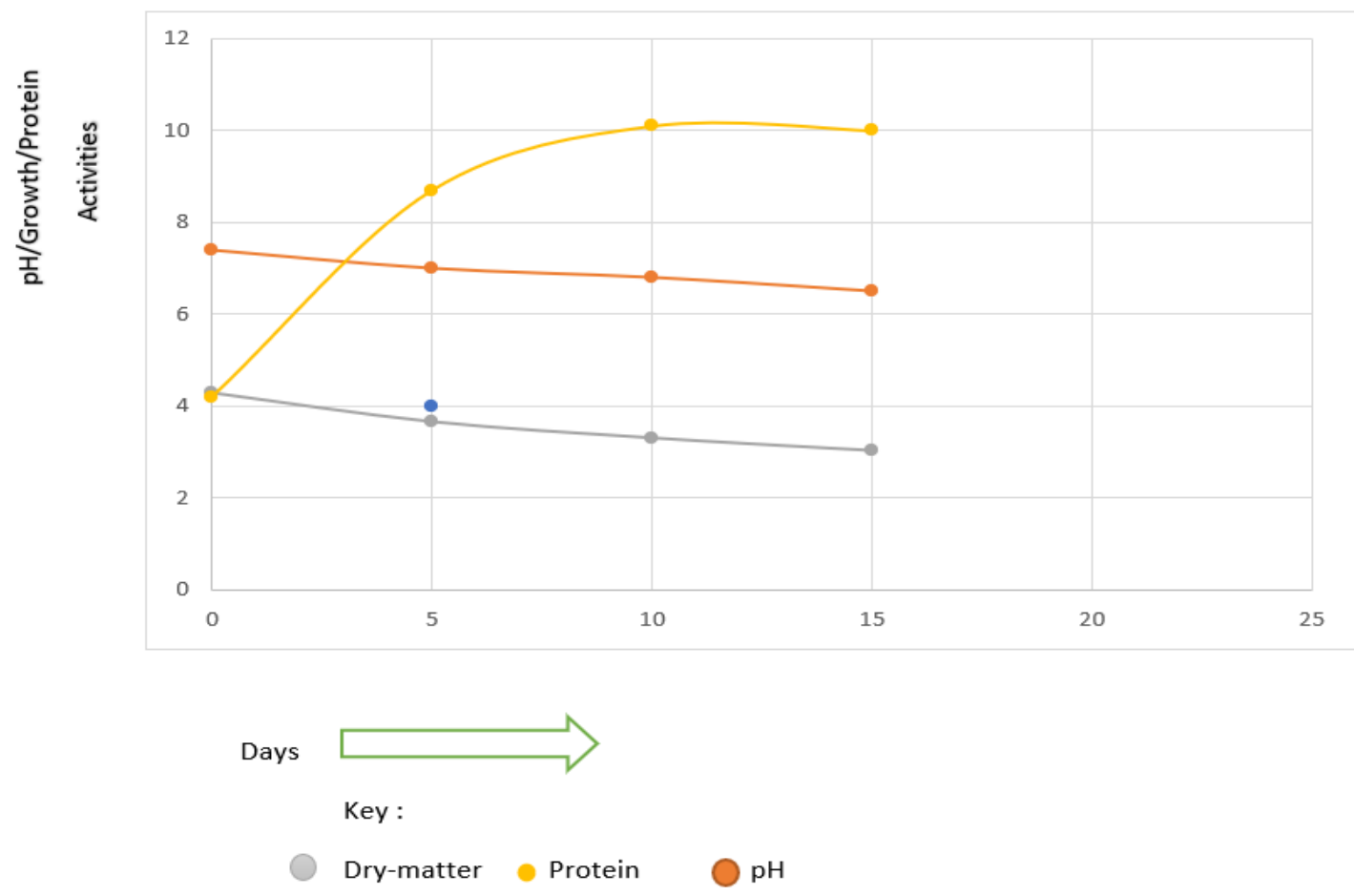

Figure: 7 : pH, Dry-matter and Protein of fermented different plan extra containing antioxidant at different time interval of fermentation using Klebsiella spices

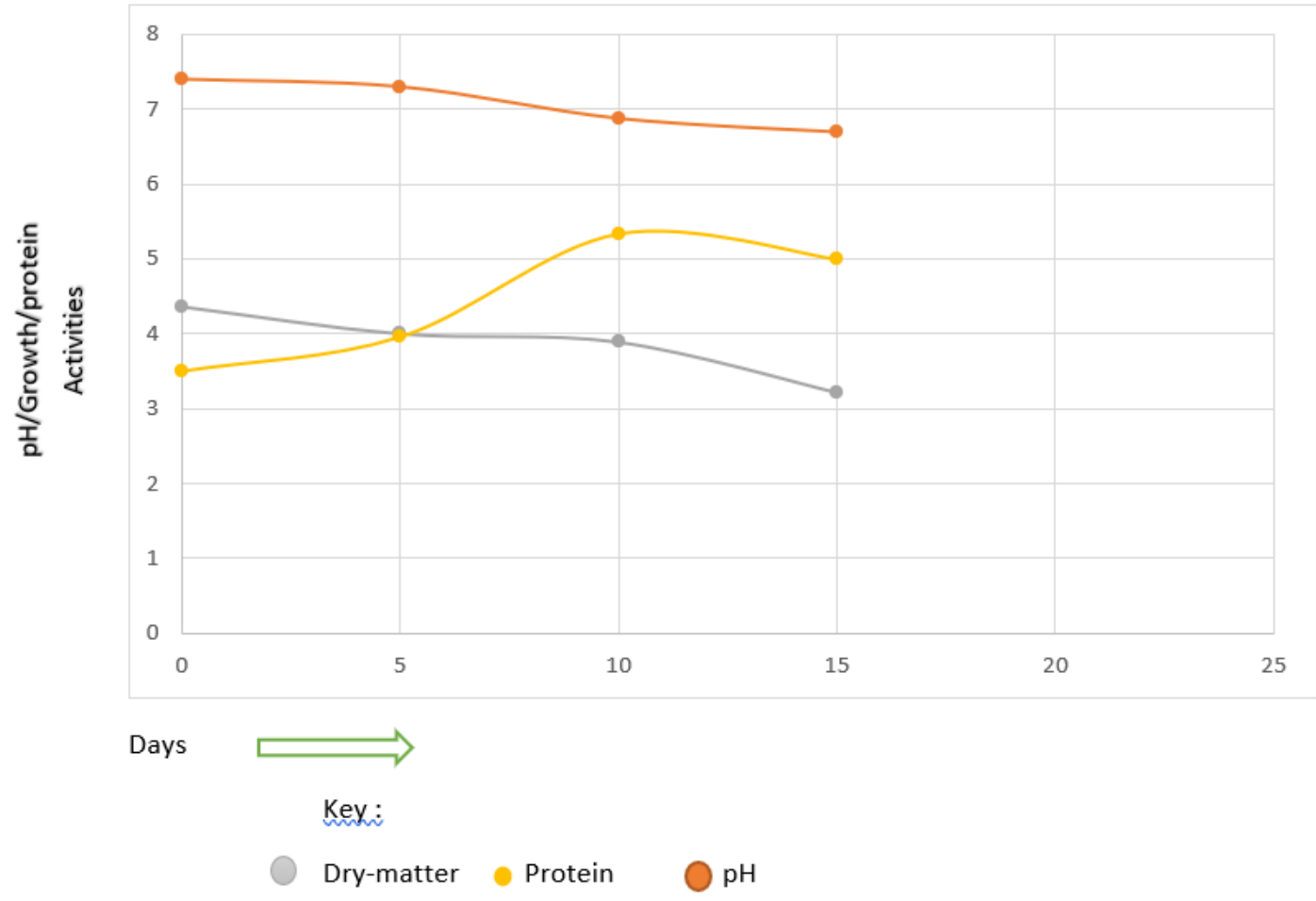

Figure: 8 : pH, Dry-matter and Protein of fermented different plan extra containing antioxidant at different time interval of fermentation using Staphylococcus species 


\section{CONCLUSION}

The naturally occurring products and phytomedicines are coming to the fore all around the world, owing to the orientation of the social fabric to such remedies in different health care centers all across the globe The global outlook for drug formulation is showing a paradigm shift as individuals are facing chronic as well as lifestyle-related disorders, due to which they are turning their stance towards improving life-styles and disease deterrence. However, during ancient period herbal Phyto-constituents were the only alternatives for healing the illness as antibiotics were not discovered. Particularly, herbal formulations endow us with toolbox to concoct novel antiviral products. This pragmatically involves the understanding of antiviral mechanisms of natural products and their role in heckling virus life-cycle, replication, assembly and its release. Ever since, the safety and clinical characteristics of traditional medicines have come out, their consumption have been gradually elevating after approval by scientific communities (divine fermented and new improved Nigeria NGO/ covid -19/ HIV/AIDS 2021). Attributable to the side-effects of chemical compounds onto human bodies, it has believed to utilize the herbal therapies with much more effectiveness and nil side-effects. Recently, WHO, has estimated that approximately $80 \%$ of the world population has been trusting the herbal therapeutics, yet, a quite a few numbers of plants have been studied for this noble work. Undeniably, traditional drugs are long in the tooth since primordial times and play a significant role to meet global health needs. Currently Silas as well as his team mate research work is creating a wave through which the Nigeria home base herbal plants have been newly employed for human consumption in time of clinical or medicinal fitness without traces of health disorders or ill symptoms in-situ. The usage of these systems in medical field is quite lucrative to flush viral infections in respiratory systems and modulating inflammatory reactions within immune systems. As depicted earlier, Silas David alongside with his team have initiated a holistic perspective of medicine to cure presently prevailing anti-viral infections via selfremedial processes without qualm.

\section{Acknowledgement}

The authors express are indebted to the team of research who might one way or the other rendered their financial support to the phase one of this project success. The authors also like to thank the management of Kaduna Poly for the motherly role they have played for the success of the project was well as the directorate of research and innovation for their moral support. Thanks

\section{REFERENCES}

1. Ahmad A., Rehman M.U., Alkharfy K.M. An alternative approach to minimize the risk of coronavirus (Covid-19) and similar infections. Eur. Rev. Med. Pharm. Sci. 2020;24(7):4030-4034. [PubMed] [Google Scholar]

2. Gautret P., Lagier J.C., Parola P., Meddeb L., Mailhe M., Doudier B., Courjon J., Giordanengo V., Vieira V.E., Dupont H.T., Honoré S. Hydroxychloroquine and azithromycin as a treatment of COVID-19: results of an open-label non-randomized clinical trial. Int. J. Antimicrob. Agents. 2020 [PMC free article] [PubMed] [Google Scholar] 
3. Wan Y., Shang J., Graham R., Baric R.S., Li F. Receptor recognition by the novel coronavirus from Wuhan: an analysis based on decade-long structural studies of SARS coronavirus. J. Virol. 2020;94(7) [PMC free article] [PubMed] [Google Scholar]

4. Chikezie P.C., Ibegbulem C.O., Mbagwu F.N. Bioactive principles from medicinal plants. Res. J. Phytochem. 2015;9(3):88-115. [Google Scholar]

5. Akram M., Tahir I.M., Shah S.M.A., Mahmood Z., Altaf A., Ahmad K., Munir N., Daniyal M., Nasir S., Mehboob H. Antiviral potential of medicinal plants against HIV, HSV, influenza, hepatitis, and coxsackievirus: a systematic review. Phytother. Res. 2018;32(5):811-822. [PubMed] [Google Scholar]

6 Tiwari, V., Darmani, N.A., Yue, B.Y., Shukla, D., 2010. In vitro antiviral activity of neem (Azardirachta indica L.) bark extract against herpes simplex virus type-1 infection. Phytother Res. 24 (8), 1132-1140.

7. Lami, N., Kadota, S., Kikuchi, T., 1992. Constituents of the roots of Boerhaavia diffusa Linn. IV. Isolation and structure determination of boeravinones D, E and F. Chem. Pharm. Bull. 39 (7), 1863-1865.

8. Verma, H.N., Awatshi, L.P., 1979. Prevention of virus infection and multiplication by leaf extract of Euphorbia hirta and the properties of the virus inhibitor. New Bot. 6, 49-59.

9. Burger, A., Torres, A.R., Warren, R.P., Caldwell, V.D., Hughes, B.G., 1997. Echinaceainduced cytokine production by human macrophages. Int. J. Immunopharm. 19, 371-379.

10. Bodinet, C., Beuscher, N., 1991. Antiviral and immunological activity of glycoproteins from Echinacea purpurea radix. Planta Med. 57 (2), A33-A34.

11. Oyewole, O.I., Oladele, J.O., Oladele, O.T., (2017). Methanolic leaf extract of Ficus Exasperata Leaf attenuates Arsenate-Mediated hepatic and renal oxidative stress in rats. Res. J. Health Sci. 5 (2), 115-123.

12. Papas, A.M., 1999. Diet and antioxidant status. Food Chem. Toxicol. 37 (9), 999-1007.

13. Oyewole, O.I., Oladele, J.O., Oladele, O.T., (2017). Methanolic leaf extract of Ficus Exasperata Leaf attenuates Arsenate-Mediated hepatic and renal oxidative stress in rats. Res. J. Health Sci. 5 (2), 115-123.

14. Hasanuzzaman, M., Hossain, M.A., da Silva, J.A.T., Fujita, M., (2011). Plant response and tolerance to abiotic oxidative stress: antioxidant defense is a key factor. In: Venteswarlu, B., Shanker, A., Maheswari, M. (Eds.), Crop Stress and its Management: Perspectives and Strategies. Springer Publisher Netherland.

15. Shebis, Y., Iluz, D., Kinel-Tahan, Y., Dubinsky, Z., Yehoshua, Y., (2013). Natural antioxidants: function and sources. Food Nutr. Sci. 4 (6), 643-649.

16. Verkerk, R.H.J., Wright, D.J., (1993). Biological activity of neem seed kernel extracts and synthetic azadirachtin against larvae of Plutella xylostella L. Pestic. Sci. 37, 83-91.

17. Chrubasik, S., Pittler, M.H., Roufogalis, B.D.,( 2005). Zingiberis rhizoma: a comprehensive review on the ginger effect and efficacy profiles. Phytomedicine 12, 684701

18. Adewole, L.O., 2002. Ageratum conyzoides L. (Asteraceae). Fitoter 73, 1-16. Agrawal, D.P., 2013. Medicinal Properties of Neem: New Findings. "Neem". Agyemang, Kojo, Han, L., Liu, E., Zhang, Yi, Wang, T., Gao, X., 2013. Recent advances in Astragalus membranaceus anti-diabetic research: pharmacological effects of its phytochemical constituents. Evid. base Compl. Alternative Med. 2013, 9. Article ID 654643.

19. Rao, J.T., Nigam, S.S.R., 1973. Ageratum conyzoides L. (Asteraceae). Aromen Koerperpfleg 23, 209-212. 
20.Nantitanon, W., Okonogi, S., 2012. Comparison of antioxidant activity of compounds isolated from guava leaves and a stability study of the most active compound. Drug Discov. Ther. 6 (1), 38-43.

21. Chaplin, D.D., 2010. Overview of the immune response. J. Allergy Clin. Immunol. 125 (2), S3-23.

22. Gupta, A., Gautam, M.K., Singh, R.K., Kumar, M.V., Rao, C.H.V., Goel, R.K., et al., 2010. Immunomodulatory effect of Moringa oleifera Lam. extract on cyclophosphamide induced toxicity in mice. Indian J. Exp. Biol. 48 (11), 1157-1160.

23. Gummert, J.F., Ikonen, T., Morris, R.E., 1999. Newer immunosuppressive drugs: a review. J. Am. Soc. Nephrol. 10 (6), 1366-1380.

24. Kyo, E., Uda, N., Kasuga, S., Itakura, Y., 2001. Immuno modulatory effects of aged garlic extract. J. Nutr. 131 (3s), 1075S-1079S.

25. Zheng J. SARS-CoV-2: an emerging coronavirus that causes a global threat. Int. J. Biol. Sci. 2020;16(10):1678-1685. doi: 10.7150/ijbs.45053. [PMC free article] [PubMed] [CrossRef] [Google Scholar]

26. Yin Y., Wunderink R.G. MERS, SARS and other coronaviruses as causes of pneumonia. Respirology. 2018;23(2):130-137. doi: 10.1111/resp.13196. [PMC free article] [PubMed] [CrossRef] [Google Scholar]

27. Lu, X., Xiang, Y., Du, H., Wing-Kin Wong, G., 2020a. SARS-CoV-2 infection in children - understanding the immune responses and controlling the pandemic. Pediatr. Allergy Immunol. 10.1111/pai.13267

28.Zheng J. SARS-CoV-2: an emerging coronavirus that causes a global threat. Int. J. Biol. Sci. 2020;16(10):1678-1685. doi: 10.7150/ijbs.45053. [PMC free article] [PubMed] [CrossRef] [Google Scholar]

29. Peng X., Xu X., Li Y., Cheng L., Zhou X., Ren B. Transmission routes of 2019-nCoV and controls in dental practice. Int. J. Oral Sci. 2020;12(1):9. doi: 10.1038/s41368-020-00759. [PMC free article] [PubMed] [CrossRef] [Google Scholar]

30.Hindson J. COVID-19: faecal-oral transmission? Nat. Rev. Gastroenterol. Hepatol. 2020;17(5):259. [PMC free article] [PubMed] [Google Scholar]

31. Xu Y., Li X., Zhu B., Liang H., Fang C., Gong Y., Zhang H. Characteristics of pediatric SARS-CoV-2 infection and potential evidence for persistent fecal viral shedding. Nat. Med. 2020;26(4):502-505

32. Poehland B.L., Carte B.K., Francis T.A., Hyland L.J., Allaudeen H.S., Troupe N. In vitro antiviral activity of dammar resin triterpenoids. J. Nat. Prod. 1987;50(4):706713. [PubMed] [Google Scholar]

33. De Clercq E. Toward improved anti-HIV chemotherapy: therapeutic strategies for intervention with HIV infections. J. Med. Chem. 1995;38(14):24912517. [PubMed] [Google Scholar]

34. Elfiky A.A. Natural products may interfere with SARS-CoV-2 attachment to the host cell. J. Biomol. Struct. Dyn. 2020:1-10. doi: 10.1080/07391102.2020.1761881. [PMC free article] [PubMed] [CrossRef] [Google Scholar]

35. Thurnher D., Turhani D., Pelzmann M., Wannemacher B., Knerer B., Formanek M., Wacheck V., Selzer E. Betulinic acid: a new cytotoxic compound against malignant head and neck cancer cells. Head Neck-J. Sci. Spec. 2003;25(9):732-740. [PubMed] [Google $\underline{\text { Scholar] }}$ 
36. Ding S., Jiang H., Fang J. Regulation of immune function by polyphenols. J. Immunol. Res. 2018 doi: 10.1155/2018/1264074. [PMC free article] [PubMed] [CrossRef] [Google Scholar]

37. Adem, S., Eyupoglu, V., Sarfraz, I., Rasul, A., Ali, M., 2020. Identification of potent COVID-19 main protease (Mpro) inhibitors from natural polyphenols: an in silico strategy unveils a hope against CORONA. DOI. 10.20944/preprints202003.0333.v1.

38. Ververidis F., Trantas E., Douglas C., Vollmer G., Kretzschmar G., Panopoulos N. Biotechnology of flavonoids and other phenylpropanoid-derived natural products. Part I: chemical diversity, impacts on plant biology and human health. Biotechnol. J.:

39. Kaul T.N., Middleton E., Jr, Ogra P.L. Antiviral effect of flavonoids on human viruses. $J$. Med. Virol. 1985;15(1):71-79. [PubMed] [Google Scholar]

40. Pilcher H. Liquorice may tackle SARS. Nature. 2003 doi: 10.1038/news03060916. [CrossRef] [Google Scholar]

41. Cinatl J., Morgenstern B., Bauer G., Chandra P., Rabenau H., Doerr H.W. Glycyrrhizin, an active component of liquorice roots, and replication of SARS-associated coronavirus. Lancet. 2003;361(9374):2045-2046. [PMC free article] [PubMed] [Google Scholar]

42. Chen F., Chan K.H., Jiang Y., Kao R.Y.T., Lu H.T., Fan K.W., Cheng V.C.C., Tsui W.H.W., Hung I.F.N., Lee T.S.W., Guan Y. In vitro susceptibility of 10 clinical isolates of SARS coronavirus to selected antiviral compounds. J. Clin. Virol. 2004;31(1):6975. [PMC free article] [PubMed] [Google Scholar]

43. Wanner, U., and Egli, T. (1990). Dynamics of microbial growth and cell composition in batch culture. FEMS Microbiol. Rev. 75, 19-44. doi: 10.1111/j.15746968.1990.tb04084.x

44. Gueguim Kana, E.B. Oloke, J.K. Lateef A. and Zebaze Kana. Constructional features of a 15- litre home-made bioreactor for fed-batch fermentations. African Journal of Biotechnology, 2003; 2: 8; Pp. 233-236.

45. Sriskantharajah S, et al. Evaluation of protocols for field decontamination before bacterial sampling of root canals for contemporary microbiology techniques. J Endod. 2003;29: 317-320. 46. Selgas M. D., Sanz B., Ordonez J. A. Selected characteristics of micrococci isolated from Spanish dry fermented sausages. Food Microbiol. 1988, 5(4), P. 185-193.

47. Doyle, M.P.; Meng, J. Bacteria in food and beverage production. In Prokaryotes; Springer: New York, NY, USA, 2006; pp. 797-811. [CrossRef]

48. Ochi K, Okamoto S, Tozawa Y , Inaoka T, Hosaka T, Xu J and Kurosawa K. Ribosome Engineering and Secondary Metabolite Production. Advances in Applied Microbiology. 2004;56:155-184.

49. Barrios Gonzalez J, Fernandez FJ and Tomasini A. Microbial secondary metabolites production and strain improvement. Indian Journal of Biotechnology. 2003; 2:322-333

50. Ghose, V.K, Ghose T.K, and Gopal Krishnan, K.S (1982). Improvement of reesei strain through mutation and selection screening technique Biotechnology and bioengineering 24, 241-243.

51. Ochi K, Okamoto S, Tozawa Y , Inaoka T, Hosaka T, Xu J and Kurosawa K. Ribosome Engineering and Secondary Metabolite Production. Advances in Applied Microbiology. 2004;56:155-184.

52. Kim Y., Kim H., Bae S., Choi J., Lim S.Y., Lee N., Kong J.M., Hwang Y.I., Kang J.S., Lee W.J. Vitamin $\mathrm{C}$ is an essential factor on the anti-viral immune responses through the production of interferon- $\alpha / \beta$ at the initial stage of influenza $A$ virus (H3N2) infection. Immune Net. 2013;13(2):70-74. [PMC free article] [PubMed] [Google Scholar] 
53. Aglipay M., Birken C.S., Parkin P.C., Loeb M.B., Thorpe K., Chen Y., Laupacis A., Mamdani M., Macarthur C., Hoch J.S., Mazzulli T. Effect of high-dose vs standard-dose wintertime vitamin D supplementation on viral upper respiratory tract infections in young healthy children. JAMA. 2017;318(3):245-254. [PMC free article] [PubMed] [Google Scholar]

54. Nimer A., Mouch A. Vitamin D improves viral response in hepatitis C genotype 2-3 naïve patients. World J. Gastroenterol. 2012;18(8):800. [PMC free article] [PubMed] [Google Scholar]

55. Grant W.B., Lahore H., McDonnell S.L., Baggerly C.A., French C.B., Aliano J.L., Bhattoa H.P. Evidence that vitamin D supplementation could reduce risk of influenza and COVID19 infections and deaths. Nutrients. 2020;12(4):988. [PMC free article] [PubMed] [Google Scholar]

56. Andreone P., Fiorino S., Cursaro C., Gramenzi A., Margotti M., Di Giammarino L., Biselli M., Miniero R., Gasbarrini G., Bernardi M. Vitamin E as treatment for chronic hepatitis B: results of a randomized controlled pilot trial. Antivir.Res. 2001;49(2):7581. [PubMed] [Google Scholar]

57. Hemilä H., Chalker E. Vitamin $\mathrm{C}$ for preventing and treating the common cold. Cochrane Database Syst. Rev. 2013 doi: 10.1002/14651858.CD000980.pub4. [PMC free article] [PubMed] [CrossRef] [Google Scholar]

58. Utomo, R.Y., Meiyanto, E., 2020. Revealing the potency of citrus and galangal constituents to halt SARS-CoV-2 infection. Preprints 2020, 2020030214 (doi: 10.20944/preprints202003.0214.v1).

59.. Pacarynuk LA, Danyk HC, Biochemical Tests. In: Principles of Microbiology, Laboratory Manual, Spring, TX, USA, 2004:28-34.

60. Bourne, D. G. and Munn, C. B. (2005). Diversity of bacteria associated with the coral Pocillopora damicornis from the great barrier reef. Environmental Microbiology, 7(8): 1162-1174.

61.ChuI, Lee C \& LiT, (1992). Enzyme Microbiol Technol 14; 467-483.

62. Oyeleke, S. B., Dauda, B.E.N. and Baye, O. A. (2008). Antibacterial Activities of Ficus capensis, Africa Journal of Biotechnology. 7(10), 1414- 1417.

63. Ofowora A.(2006) Medicinal plants and Traditional Medicine in Africa. Spectrum Books, Ibadan 289.

64. Elezabeth, V. and Arumugam, S., Study of the phytochemical analysis and antimicrobial activity of Cyperus rotundus leaves. International journal of current biotechnology. Mainspringer Publishers. ISSN: 2321-8371 (2013). 20.

65. Sivapalan, S. R. and Jeyadevan, P., Physico-chemical and phytochemical study of rhizome of Cyperus rotundus Linn. International Journal of Pharmacology and Pharmaceutical Technology, 1(2): pp. 42-46 (2012). 21

66. Sharma, S. K. and Singh, A. P., Morphological microscopical and physicochemical investigations on the rhizomes of Cyperus rotundus Linn. Res J Pharm Biol Chem Sci, 2: pp. 798-806 (2011). 22.

67. Emelugo, B. N., Umerie, S. C., Okonkwo, I. F. and Achufusi, J. N., Evaluation of the tubers and oil of Cyperus rotundus Linn (Cyperaceae). Pak J Nutr, 10(2): pp. 147- 150 (2011). 23.

68. Ghannadi, A., Rabbani, M., Ghaemmaghami, L. and Malekian, N., Phytochemical screening and essential oil analysis of one of the persian sedges; Cyperus rotundus L. International Journal of Pharmaceutical Sciences and Research, 3(2): p. 424 (2012). 
69. Muhammad SA \& Abubakar SM (2016) Qualitative and Quantitative Determination of Phytochemicals in Aqueous Extract of Chrysophyllum albidum Seed Kernel. Biosciences Biotechnology Rese

70. Zhishen J, Mengecheng T, Jianming W., The determination of flavonoid content on mulberry and their scavenging effects on superoxide radical. Food Chem.,1999, 64, 555559

71.. Siddhuraju P and Becker K. Antioxidant properties of various solvent extracts of total tannins constituents from three different agroclimatic origins of Drumstick tree (Moringa oleifera Lam.) leaves, J Agric Food Chem., 2003, 51, 2144 -2155.

72. El- Olemy, MM., Al- muhtadi, F.J., and Afifi., A.F.A (1994). Experimental phyto chemistry: A laboratory manual. King Saud University Press Saudi Arabia, 1994, 21-27.

73. Muhammad SA \& Abubakar SM (2016) Qualitative and Quantitative Determination of Phytochemicals in Aqueous Extract of Chrysophyllum albidum Seed Kernel. Biosciences Biotechnology Rese

74. Nag A. (2006). Analytical Techniques in Agriculture, Biotechnology and Environmental Engineering. Prentice-Hall of India, New Delhi, pp 84-102.

75. Nag A. (2006). Analytical Techniques in Agriculture, Biotechnology and Environmental Engineering. Prentice-Hall of India, New Delhi, pp 84-102.

76. Nag A. (2006). Analytical Techniques in Agriculture, Biotechnology and Environmental Engineering. Prentice-Hall of India, New Delhi, pp 84-102

77. Onyeike E. N. and Osuji, J. O. (2003): Research Techniques In Biological and Chemical Science. Springfield Publishers Ltd Owerri.

78. Nag A. (2007). Analytical Techniques in Agriculture, Biotechnology and Environmental Engineering. Prentice-Hall of India, New Delhi, pp 84-102

79. Nag A. (2006). Analytical Techniques in Agriculture, Biotechnology and Environmental Engineering. Prentice-Hall of India, New Delhi, pp 84-102

80. Nag A. (2006). Analytical Techniques in Agriculture, Biotechnology and Environmental Engineering. Prentice-Hall of India, New Delhi, pp 84-102

81.Sharma, A., Goyal, R., \& Sharma, L. (2015). Potential biological efficacy of Pinus plant species against oxidative, inflammatory and microbial disorders. BMC complementary and alternative medicine, 16(1), 35 .

82. Campelo, A.F. and Belo,I. (2004). Fermentative capacity of baker's yeast exposed to hyperbaric Stress. Biotechinol. Lett. Pp 1237-1240.

83. Moon S H and Parulekar S. J A (1991), A parametric study of proease production in batch and fed btch culture of bacillus sp, Biotechnology Bioeng, 37, 467-483

84. Lincoln R. E (1960), Control of stock culture preservation and inoculum build up in bacterial fermentation, J. Biochem, Microbial Tech Eng, 2, 481-500.

85. Sen S\&Satyanarayana T, (1993). Optimization of alkaline protease production by thermophilic Bacillus licheniformis S-40, Indian J Microbiol 33(1), 43-47

86. El Haddad M, Gracheva, IM \& Gryaznorva S V(1974). Effect of homogeneity of the culture, age and inoculum size on the biosynthesis of amylolytic enzymes by bacillus mesentericus, P B, Microbiogia, 10, 365-368.

87. Badia-Boungou, F., Sane, F., Alidjinou, E. K., Hennebelle, T., Roumy, V., NgakegniLimbili, A. C., et al. (2019). Aqueous extracts of Syzygium brazzavillense can inhibit the infection with coxsackievirus B4 in vitro. J. Med. Virol.91 (7), 1210-1216. doi:10.1002/jmv.25436 
88. Afolayan, F. I. D., Adegbolagun, O., Mwikwabe, N. N., Orwa, J., and Anumudu, C. (2020). Cytokine modulation during malaria infections by some medicinal plants. Scientific Afr. 8, e00428. doi:10.1016/j.sciaf.2020.e00428

89 Fialho, L. G., da Silva, V. P., Reis, S. R. N. I., Azeredo, E. L., Kaplan, M. A. C., Figueiredo, M. R., et al. (2016). Antiviral and immunomodulatory effects of norantea brasiliensis choisy on dengue virus-2. Intervirology 59 (4), 217-227. doi:10.1159/000455855

90. Esimone, C. O., Grunwald, T., Wildner, O., Nchinda, G., Tippler, B., Proksch, P., et al. (2005). In vitro pharmacodynamic evaluation of antiviral medicinal plants using a vectorbased assay technique. J. Appl. Microbiol. 99 (6), 1346-1355. doi:10.1111/j.13652672.2005.02732.x

91. Jassim, S. A. A., and Naji, M. A. (2003). Novel antiviral agents: a medicinal plant perspective. J. Appl. Microbiol. 95 (3), 412-427. doi:10.1046/j.1365-2672.2003.02026.x

92, Roy A, Bharadvaj N (2017) Qualitative analysis of phytocompounds and synthesis of silver nanoparticles from Centella asiatica. Innov Techn Agri 1: 88-95.

93. Avery M L. Avian repellents. USDA National wildlife research center - staff publications. 2002; 122-129.

94. Ivory K., Prieto E., Spinks C., Armah C.N., Goldson A.J., Dainty J.R., Nicoletti C. Selenium supplementation has beneficial and detrimental effects on immunity to influenza vaccine in older adults. Clin. Nutr. 2017;36(2):407-415. [PMC free article] [PubMed] [Google Scholar]

95 Nimer A., Mouch A. Vitamin D improves viral response in hepatitis C genotype 2-3 naïve patients. World J. Gastroenterol. 2012;18(8):800. [PMC free article] [PubMed] [Google Scholar]

96. Grant W.B., Lahore H., McDonnell S.L., Baggerly C.A., French C.B., Aliano J.L., Bhattoa H.P. (2020). Evidence that vitamin D supplementation could reduce risk of influenza and COVID-19 infections and deaths. Nutrients.;12(4):988. [PMC free article] [PubMed] [Google Scholar]

97. Utomo, R.Y., Meiyanto, E., 2020. Revealing the potency of citrus and galangal constituents to halt SARS-CoV-2 infection. Preprints 2020, 2020030214 (doi: 10.20944/preprints202003.0214.v1).

98. McCarty, M.F., DiNicolantonio, J.J., 2020. Nutraceuticals have potential for boosting the type 1 interferon response to RNA viruses including influenza and coronavirus. Prog. Cardiovasc. Dis. DOI.10.1016/j.pcad.2020.02.007. [PMC free article] [PubMed]

99. Bunout D., Hirsch S., de la Maza M.P., Munoz C., Haschke F., Steenhout P., Klassen P., Barrera G., Gattas V., Petermann M. Effects of prebiotics on the immune response to vaccination in the elderly. J. Paren. Ent. Nutr. 2002;26(6):372-376. [PubMed] [Google Scholar]

100. touseefe \& Yin A, (1987). Biotech Microbiol lett 5, 351

101. Silas D. E, Dunah, C,S and DE, N(2004). Protein enrichment of spent sorghum residue using Candida species and Saccharomyces cerevisiae, Nig. Biotechn. 15(1) 22-29

102, Loveley D R, Woodward J.C \& Chepelle F H,(1996). Nature, 62, 288-291. 